\title{
UNIFORMIDADE DE DISTRIBUIÇÃO DE ÁGUA POR ASPERSÃO CONVENCIONAL NA PRESENÇA DA CULTURA DO MILHO
}

PAULO MÁRCIO MUNDIM

Engenheiro Agrônomo

Orientador: Prof. Dr. MARCOS VINÍCIUS FOLEGATTI

Dissertação apresentada à Escola Superior de Agricultura "Luiz de Queiroz", da Universidade de São Paulo, para obtenção do título de Mestre em Agronomia, Área de Concentração: Irrigação e Drenagem.

P I R A C I C A B A

Estado de São Paulo - Brasil

$$
\text { Maio - } 1996
$$


Dados Internacionais de Catalogação na Publicação (CIP) DIVISÃO DE BIBLIOTECA E DOCUMENTAÇĀO - Campus “Luiz de Queiroz"/USP

Mundim, Paulo Márcio

Uniformidade de distribuição de água por aspersão convencional na presença da cultura do milho / Paulo Márcio Mundim. - - Piracicaba, 1996.

$82 \mathrm{p}$. 1996.

Dissertação (mestrado) - - Escola Superior de Agricultura Luiz de Queiroz,

Bibliografia.

1. Água - Distribuição - Uniformidade 2. Irrigação por aspersão 3. Milho Irrigação - Efeito

CDD $\quad 631.7$

633.15 


\section{UNIFORMIDADE DE DISTRIBUIÇÃO DE ÁGUA POR ASPERSÃO CONVENCIONAL NA PRESENÇA DA CULTURA DO MILHO}

\section{PAULO MÁRCIO MUNDIM}

Aprovada em: 28.06 .1996

Comissão Julgadora:

Prof. Dr. Marcos Vinícius Folegatti

ESALQ/USP

Prof. Dr. José Antônio Frizzone ESALQ/USP

Prof. Dr. Fernando Braz Tangerino Hernandez

UNESP - ILHA SOLTEIRA

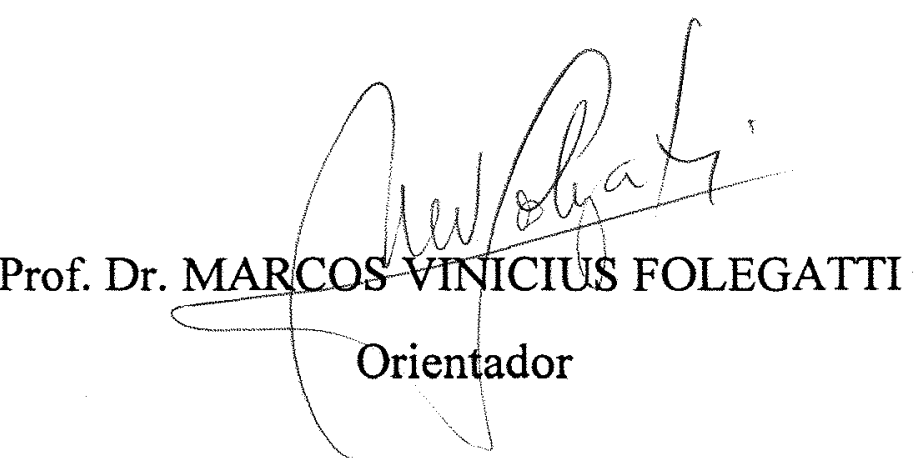


Ao Senhor Deus, em primeiro lugar, a gratidão - o louvor pelo sustento, direção, consolo e ensino indispensáveis ì vida.

Aos meus pais Oseavu e Jraey pelo amor exemplo contínuos; aos tios agrônomos Gthoniel e Paulo pelo estímulo e apoio resoluto em todas as horas, ofereço.

À querida esposa Denair, euja sabedoria, dedieação e amor possibilitaram nossa vitória nesta empreitada, dedico. 


\section{AGRADECIMENTOS}

- À EMATER-RIO pela possibilidade de realização deste curso, prova do seu zelo pela capacitação do seu corpo técnico;

- Ao Prof. Marcos Folegatti pela amizade, orientação, apoio e estímulo;

- Aos professores do Departamento de Engenharia Rural pelos ensinamentos intra e extra classe;

- Às bancas do exame de qualificação e de defesa pelas sugestões apresentadas;

- Ao Departamento de Engenharia Rural da ESALQ/USP, pelas condições fisicas para a realização do presente trabalho;

- Aos funcionários do DER-ESALQ/USP: Gilmar, Hélio, Márcio, Renato, Zezinho, Roberta, Sílvia e Vera pelo auxílio em todas as fases do trabalho;

- Ao colega Antônio Carlos Andrade Gonçalves pela disposição contínua em ajudar e esclarecer;

- Aos colegas de turma pelo convívio alegre e instrutivo;

- A todos os que direta ou indiretamente contribuíram para a execução do presente trabalho. 


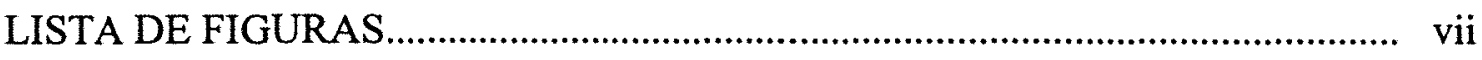

LISTA DE QUADROS.................................................................................. viii

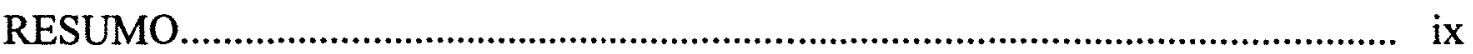

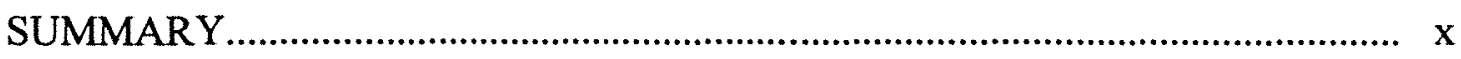

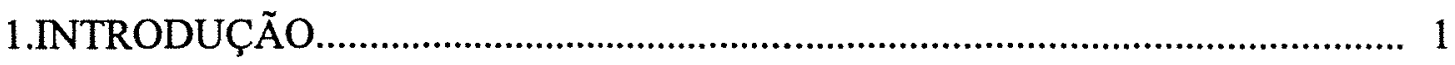

2. REVISÃO BIBLIOGRÁFICA.................................................................. 4

2.1 Uniformidade de Distribuição de Água por Sistemas de Aspersão.................... 4

2.2 Cultura do Milho............................................................................................ 11

2.3 Intercepção da Precipitação pela Cultura do Milho........................................... 12

3. MATERIAL E MÉTODOS........................................................................ 18

3.1 Condução da Cultura..................................................................................... 18

3.2 Irrigação....................................................................................................... 19

3.3 Estimativa da Uniformidade de Distribuição.................................................... 20

3.4 Precipitação Interna e Escoamento pelo Colmo................................................. 22

3.5 Desenvolvimento da Cultura.......................................................................... 23

4. RESULTADOS E DISCUSSÃO................................................................ 25

4.1 Desenvolvimento da Cultura............................................................................. 25

4.2 Uniformidade de Irrigação............................................................................. 27

4.3 Escoamento pelo Colmo e Precipitação Interna...................................................... 31

4.4 Perfil de Distribuição da Água Através das Entrelinhas................................... 34

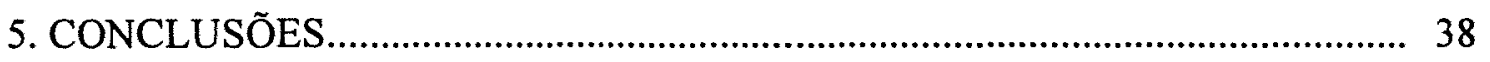

REFERÊNCIAS BIBLIOGRÁFICAS............................................................. 40

APÊNDICE 1 - Escoamento pelo Colmo............................................................... 44

APÊNDICE 2 - Condições Climáticas do Período de Experimento.......................... 48

APÊNDICE 3 - Índice de Área Foliar e Altura das Plantas .................................... 52

APÊNDICE 4- Manejo da Irrigação...................................................................... 54

APÊNDICE 5 - Testes de Uniformidade.................................................................. 64

APÊNDICE 6 - Perfil de Distribuição de Água Abaixo da Cultura........................... 79 


\section{LISTA DE FIGURAS}

FIGURA

página

1- Esquema da tubulação com os aspersores........................................ 18

2 - Disposição dos coletores em relação às linhas de semeadura........... 20

3 - Coletores de escoamento pelo colmo............................................ 21

4 - IAF e altura das plantas em função da soma térmica para as três

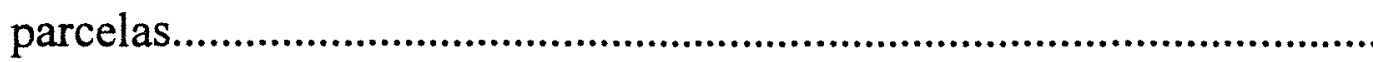

5 - Rendimento em função do CUC de distribuição.............................. 26

6 - CUC abaixo da folhagem em função do desenvolvimento da

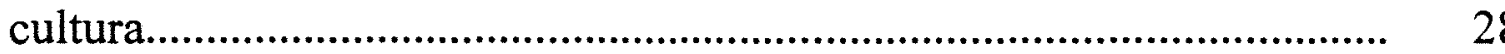

7 - Precipitação interna em função do desenvolvimento da cultura.......

8 - Escoamento pelo colmo e precipitação interna em função da precipitação total

9 - Escoamento pelo colmo e precipitação interna em relação à precipitação efetiva para as três parcelas.

10 - Perfil de distribuição da precipitação efetiva em relação à Pt entre as linhas de semeadura. 


\section{LISTA DE QUADROS}

\section{QUADRO}

Página

01 - Valores de Kc e percentual de esgotamento para o milho...............

02 - Características operacionais do aspersor FABRIMAR A1823 segundo catálogo do fabricante............................................................

04 - Divisão média da $\mathrm{Pi}(\%)$ por fase em relação à distância entre o coletor e a linha de semeadura.. 05 - Distribuição do volume aplicado conforme a distância da linha de plantio 


\title{
UNIFORMIDADE DE DISTRIBUIÇÃO DE ÁGUA POR ASPERSÃO CONVENCIONAL NA PRESENÇA DA CULTURA DO MILHO
}

\author{
Autor: PAULO MÁRCIO MUNDIM \\ Orientador: PROF. DR. MARCOS VINÍCIUS FOLEGATTI
}

\section{RESUMO}

A uniformidade de distribuição de água por sistemas de aspersão é determinada em condições de laboratório ou campo sobre solo nu. A cultura, no entanto, pode alterar esta distribuição de água ao longo do seu ciclo. Neste trabalho investigou-se a influência da cultura do milho na distribuição de água, em três níveis de Coeficientes de Uniformidade de Christiansen: Parcela I, com CUC $=62 \%$, Parcela II com CUC $=73 \%$ e Parcela III, com CUC $=89 \%$, descrevendo também o perfil desta distribuição entre as linhas de plantio. A cultura do milho reduziu o CUC com que a água foi distribuída pelo equipamento para valores estimados de até $4 \%, 10 \%$ e $20 \%$ nas três parcelas respectivamente. Observou-se que cerca de metade da precipitação total $(44,5$ e $50,0 \%$ respectivamente) chegou ao solo via escoamento pelo colmo (Ec) nas parcelas I e II, enquanto na III houve maior precipitação interna $(61,2 \%)$ que Ec $(38,8 \%)$. Os valores de precipitação e de intensidade de precipitação afetaram o perfil desta distribuição. A consideração destes fatos pode ser útil na otimização de quimigações. 


\title{
WATER APPLICATION UNIFORMITY BY
}

SOLID SET SYSTEM UNDER CORN CROP

SUMMARY

\author{
Author: PAULO MÁRCIO MUNDIM \\ Adviser: PROF. DR. MARCOS VINÍCIUS FOLEGATTI
}

The determination of irrigation uniformity distribution can be done in the field over a bare soil on in the laboratory. However, just a few works consider the influence of the crop on the water distribution. This work verified the influence of the corn crops on the water distribution in a sprinkler solid set system with three Christiansen's Uniformity Coefficient: Parcel I (CUC=62\%), II (CUC $=73 \%)$ and III $(\mathrm{CUC}=89 \%)$ and also described water distribution profile across plant lines. Corn plants reduced uniformity (CUC) to $4 \%, 10 \%$ and $20 \%$ in the three parcels respectively. About fifty percent of the total rainfall reached the soil by stemflow on the parcels I and II, and $40 \%$ in the parcel III. The water aplication rate and the total water aplication affected the water distribution. These facts may be useful to optimize chemigation. 


\section{INTRODUÇÃO:}

Segundo Chaudhry (1975), o desempenho dos aspersores vem sendo pesquisado desde a década de 30. Christiansen propôs em 1942 um Coeficiente de Uniformidade que tem sido amplamente utilizado na avaliação do desempenho de sistemas de aspersão. Desde então, diversos autores têm trabalhado com índices de uniformidade de distribuição, seja criticando o seu uso inadequado, seja relacionando-os à produção e custos, ou aprimorando a metodologia de sua obtenção.

A avaliação da distribuição de água de um aspersor é feita em laboratório ou no campo em condições normatizadas pela ASAE e/ou, no Brasil, pela ABNT. O coeficiente de uniformidade do sistema será fruto da extrapolação dos resultados obtidos para o aspersor isoladamente, ou poderá ser obtido a campo conjugando a performance de diversos aspersores.

No campo, no entanto, percebe-se que a água distribuída pelo equipamento de aspersão tem, em seu caminho até as raízes, fatores intervenientes que poderão alterar sua distribuição espacial e temporal. Tais fatores são a deriva por vento, a evaporação das gotas menores nas horas quentes do dia, a folhagem da cultura e o solo. 
A interferência da folhagem, no caso de culturas anuais, será diferente em cada fase do ciclo: pequena de início, evoluirá até um patamar com o pleno desenvolvimento vegetativo, e decairá em seguida com a senescência das folhas. Diferentes espécies causarão diferentes alterações, podendo ocorrer tanto um aumento como uma diminuição na uniformidade de distribuição da água.

A interferência do solo ocorre através do seu microrelevo e do processo de redistribuição de água regido pelas diferenças de potencial da água no solo. Autores como Rezende (1992) e Paiva (1980) têm realizado trabalhos que visam avaliar a capacidade de redistribuição de água pelo solo partindo de diferentes uniformidades de distribuição.

A distribuição de água é importante no caso de se trabalhar com quimigação, principalmente quando esta visa o solo. Altas uniformidades de distribuição são necessárias para o uso de tal técnica, até mesmo porque nem sempre se poderá contar com a redistribuição do produto químico pelo solo, cujas cargas elétricas farão com que tal redistribuição não seja regida somente pelas diferenças de potencial hídrico. A presença da cultura poderá favorecer ou atrapalhar (e quem sabe impedir) a aplicação de determinados produtos químicos via irrigação. No caso do milho e cana, por exemplo, é de se esperar que sua capacidade de direcionar grande parte da água aspergida diretamente ao colmo e à zona radicular favoreçam a eficiência da fertirrigação. O efeito contrário será obtido, no entanto, ao se proceder uma herbigação ou qualquer tentativa de se aplicar determinado produto uniformemente sobre área total. 
A alteração da distribuição de água implicará na alteração da precipitação. No caso de gramíneas como milho e cana tal efeito, intensificado pelo formato de suas folhas, pode resultar, por exemplo, em aumento das perdas por percolação.

Há poucas informações sobre o que ocorre com a distribuição da água aplicada por aspersão em condições de campo; isto porque poucos trabalhos abordaram esta questão, avaliando a capacidade das culturas em alterar a distribuição da água aspergida.

O objetivo deste trabalho foi estudar a influência da cultura do milho, ao longo do seu ciclo, sobre a uniformidade de distribuiçào de água aplicada por aspersão. Utilizou-se como referência coeficientes de uniformidade de Christhiansen (CUC), acima da folhagem, de $62 \%, 73 \%$ e $89 \%$. 


\section{REVISÃO BIBLIOGRÁFICA}

\section{1- Uniformidade de Distribuição de Água por Sistemas de Aspersão}

Wilcox (1947) já afirmava que a grande vantagem da aspersão era a uniformidade com que distribuía a água sobre a área irrigada. Para expressar numericamente essa uniformidade foram propostos diversos coeficientes, entre eles o coeficiente de uniformidade de Christiansen (1942):

$$
C U C=100\left[1-\frac{\sum\left|X_{I}-\bar{X}\right|}{n \cdot \bar{X}}\right]
$$

Tais coeficientes expressam a variabilidade da lâmina aplicada através de medidas de dispersão expressas na forma adimensional, pela comparação com o valor médio. Segundo Frizzone (1992), o coeficiente de uniformidade de Christiansen (CUC) não é substituído com vantagens por nenhum dos outros coeficientes já propostos.

Alguns dos fatores que afetam a uniformidade de distribuição são amplamente discutidos: pressão de serviço, bombeamento inadequado, desuniformidade de fabricação, 
variações na linha dos aspersores, espaçamento entre eles, taxa de aplicação, evaporação, velocidade do vento, topografia, altura do tubo de elevação, velocidade de rotação, tensão da mola do aspersor e outros (Hermann et al,1992 e Frizzone,1992). Alguns deles têm seus efeitos atenuados ao longo das sucessivas operações do sistema, como no caso do vento, inclinação do tubo de subida e variações na velocidade de rotação. Outros têm seus efeitos repetidos, como por exemplo os devidos à perda de carga na tubulação, ao movimento superficial da água antes da infiltração e à má distribuição de água no perímetro da área.

A determinação da uniformidade de distribuição é feita em testes utilizando-se um ou mais aspersores, dispondo ao seu redor um número suficiente de pluviômetros para que no mínimo 50 recebam água. Tais pluviômetros devem estar regularmente espaçados e captar a lâmina aplicada em um tempo de funcionamento superior a 1 hora ou suficiente para aplicação de $5 \mathrm{~mm}$ de lâmina (Frizzone,1992). A ASAE (1984) normatiza o teste de uniformidade com uso de 80 coletores instalados de maneira a formar com suas bordas um plano visualmente horizontal. O vento deve ser nulo ou fraco durante o teste. Merriam et al (1983) afirmam que 20 coletores espaçados de 3 metros entre si seriam necessários para uma razoável precisão do teste, que deveria ser longo o suficiente para que se captasse no mínimo $10 \mathrm{~mm}$ de lâmina nos coletores. De qualquer forma, afirmam que erros menores que $3 \%$ não devem ser esperados.

Segundo Hermann et al (1992), os pluviômetros devem ter paredes finas, ser altos o suficiente para evitar respingos e ser instalados rigorosamente na horizontal. A 
evaporação durante o teste deve ser considerada e seu valor descontado das lâminas coletadas. Branscheid \& Hart (1968), comparando a determinação do coeficiente de uniformidade de Hart com o uso de um ou vários aspersores, concluíram ser a primeira forma perfeitamente válida.

Livingston et al (1985) e Kohl (1972) abordaram questões como formato e tamanho de coletores, uso de supressores de evaporação e efeitos do vento e temperatura sobre os testes.

De posse das lâminas coletadas simula-se a sobreposição a ser obtida com o espaçamento pretendido e calcula-se o coeficiente de uniformidade de distribuição preferido. Em razão da variação de pressão ao longo da tubulação, a uniformidade do sistema como um todo será diferente daquela obtida pela metodologia acima. Keller \& Bliesner (1990) afirmam que, uma vez que a vazão de um aspersor varia com a raiz quadrada de sua pressão de serviço, e o CUC com a vazão média da menor metade, o CUC de um sistema de irrigação pode ser estimado por

$$
\text { CUC do sistema }=\text { CUC. } \frac{1+\left({ }^{\mathrm{Pm} / \mathrm{Pa}}\right)^{0,5}}{2}
$$

onde $\mathrm{P}_{\mathrm{m}}=$ pressão de operação mínima e $\mathrm{P}_{\mathrm{a}}$ =pressão de operação média.

Estes autores apresentam também uma compreensão prática das implicações da uniformidade de distribuição de água. Citam uma combinação de uniformidade de distribuição com área adequadamente irrigada para fornecer a eficiência de distribuição, apresentando as relações em forma de uma tabela, válida para valores de CUC quando a distribuição de água segue um padrão normal. Por exemplo: para um CUC de 80\%, 
supondo-se que se deseje irrigar adequadamente $75 \%$ da área, tem-se que a eficiência de distribuição seria de $83 \%$, ou seja: para cada $1 \mathrm{~mm}$ de lâmina que se deseje aplicar ao solo deve-se aspergir $1 / 0,83=1,2 \mathrm{~mm}$ de água. Já com um sistema que forneça CUC de $70 \%$, para irrigar adequadamente o mesmo percentual da área ter-se-ia uma eficiência de aplicação de $75 \%$, ou seja; seriam necessários $1 / 0,75=1,33 \mathrm{~mm}$ de água, ou aproximadamente $11 \%$ a mais. É interessante notar que, para uma área adequadamente irrigada de $80 \%$, os valores de CUC e eficiência de distribuição são praticamente coincidentes. Soares (1992) sugere que a área deficientemente irrigada varie entre $10 \mathrm{e}$ $20 \%$, de acordo com o valor comercial da cultura implantada.

Rezende (1992) considera a uniformidade de distribuição como um parâmetro de comparação entre sistemas. Dentre dois que distribuam a mesma lâmina, o mais uniforme será mais eficiente.

Segundo Frizzone (1992), em aspersão, alta uniformidade está relacionada a menores espaçamentos entre aspersores e maiores custos. Seria recomendada portanto para culturas de alto valor econômico e/ou sistema radicular raso.

Zocoler (1994) estudou a variação de custos para uma mesma configuração de sistema de aspersão (pressão de serviço e diâmetro de bocais), variando apenas o espaçamento. A partir de seus dados gerou a equação CAT $=110,03+1,64$.CUC para valores de CUC maiores que $70 \%$ atingindo até $96 \%$. A equação, embora significativa, teve baixo coeficiente de determinação, ou seja: somente parte da variação do CAT 
(Custo Anual Total ) é explicada pela equação. Observa-se que, para variação de um ponto percentual de CUC, há aumento de US\$1,6/ ha no CAT.

O uso de "posições alternadas" é uma maneira relativamente fácil e pouco onerosa de incrementar a uniformidade obtenível com dado sistema. Este expediente consiste em posicionar as laterais, a cada irrigação, a meia distância das posições utilizadas na irrigação anterior, o que seria aproximadamente equivalente a trabalhar com metade da distância entre linhas. O valor do CUC obtido após cada par de irrigações seria aproximado por $\left[C^{\prime} C^{\prime}=10 .(C U C)^{0,5}\right]$ (Keller \& Bliesner,1990). É necessário cuidado, no entanto, quando o valor de CUC é muito baixo e o intervalo entre irrigações longo. Lima \& Scaloppi (1995), trabalhando com alternância de posições não só da linha lateral como também da principal, com diferentes espaçamentos, encontraram aumento no valor de CUC de 4,4\% em relação à posição fixa, observando ainda que o efeito da alternância de posição dos aspersores foi maior em condições de distribuição menos uniforme e de ventos ausentes ou fracos, e que a alternância simultânea das linhas lateral e principal com deslocamento de 6 metros mostrou-se a melhor opção nas condições dos ensaios.

O critério de adotar-se um valor de CUC ao redor de $80 \%$ em projetos de irrigação por aspersão é amplamente aceito. Segundo Keller \& Bliesner (1990), mesmo reconhecendo a relatividade das definições de 'alta' e 'baixa' uniformidades, valores de CUC acima de $85 \%$ seriam recomendáveis para culturas sensíveis e de raízes rasas; entre 75 e $83 \%$ para culturas com sistema radicular de média profundidade, e acima de $70 \%$ 
para o caso de sistemas radiculares profundos. No caso de quimigação, altos valores de CUC seriam necessários, até mesmo porque a uniformidade de distribuição dos produtos químicos pode ser inferior à uniformidade de distribuição da água, como ocorre, por exemplo, com os formulados em óleo (Vieira,1994).

Von Bernuth (1983) argumenta que a definição de um valor desejável de uniformidade só é válida na ausência de restrição (legal ou econômica) ao uso da água. Havendo tal restrição (o que a nosso ver quase sempre ocorre em projetos de aspersão), a uniformidade deixaria de ser um critério e passaria a ser um parâmetro de projeto, e seu valor função de custos e expectativas de receita. Baseado nisso apresenta um método para determinar a uniformidade ótima de projeto quando o fator água é limitante e elabora um exemplo do uso de sua função para a cultura do milho. Observa-se no seu modelo que o coeficiente de uniformidade de Hart (CUH) ótimo aumenta com o valor do produto e com a lâmina média possível de ser aplicada (ou seja, com a disponibilidade de água). Valores de CUH entre $52,7 \%$ e $93,3 \%$ são sugeridos de acordo com os dois fatores considerados.

Letey et al (1984) concordam com tal pensamento, afirmando que, no caso de insuficiência de água, baixos valores de uniformidade permitem que ao menos parte da área seja adequadamente irrigada, enquanto altos valores fariam com que toda ela sofresse déficit.

Solomon (1984) afirma que em alguns casos a produção pode ser expressa como função da uniformidade e eficiência de irrigação. Von Bernuth (1983) utiliza uma função 
de produção para demonstrar que, trabalhando-se com níveis de irrigação abaixo do ótimo econômico a uniformidade de distribuição influenciará significativamente a produção. Acima daquele nível, no entanto, isto não se verifica.

Letey et al (1984) analisam conceitualmente essa relação. Segundo eles, em culturas pouco sensíveis ao encharcamento, quando as lâminas aplicadas são insuficientes, menor uniformidade leva a maiores retornos econômicos (pelo menos parte da área receberia água suficiente, ao contrário do que ocorreria numa irrigação de alta uniformidade). Os danos da baixa uniformidade, ainda segundo estes autores, são maiores em solos com tendência a encharcamento, baixa capacidade de retenção, pequena profundidade efetiva e em épocas de maior evapotranspiração. Admitem no entanto que baixas uniformidades levam a baixas produções, e que podem ser contrabalançadas pelo aumento da lâmina aplicada quando seu custo é baixo. Há no entanto que se considerar neste caso também a lixiviação de nutrientes.

Percebe-se que a uniformidade ótima para um projeto depende das condições locais e de preços do produto e de insumos (e estes variam no tempo), podendo-se utilizar valores menores que os tradicionais de projeto quando se tem restrição na quantidade de água disponível (Von Bernuth,1983).

Chaudhry (1975) afirma que "a principal desvantagem do uso dos coeficientes é a negligência de fatores que afetam diretamente o projeto do sistema: tipo de cultura, solo, clima, colheitas e custos anuais", com o que concorda Frizzone (1992). 


\section{2- Cultura do Milho}

Segundo EMBRAPA-CNPMS (1983), a área plantada com milho no Brasil atinge 11,5 milhões de hectares, a maior de todos os produtos agrícolas, e o seu consumo pela população (como óleo, farinha, fubá, milho verde, etc...) é de $33 \mathrm{~kg} /$ habitante.ano $^{-1}$, sobrepujado apenas pelo verificado no México. Estes dois fatos dão a percepção da importância da cultura no país.

O mesmo autor afirma que há disponibilidade de variedades desde precoces, cuja colheita pode ser feita aos três meses da semeadura, até tardias, adaptadas às regiões úmidas equatoriais, com ciclo de 10 meses ou mais. Costa et al (1992), trabalhando com consumo de água pelo milho em 36 épocas de plantio observaram alongamento do ciclo nos plantios de inverno e nos irrigados, independentemente da época. Tal alongamento no inverno seria devido, segundo os autores, à baixa temperatura. Numa análise mais detalhada, Doorenbos \& Kassam (1994) afirmam que, quando as temperaturas médias diárias durante o período de crescimento são maiores que $20^{\circ} \mathrm{C}$, as variedades precoces levam de 80 a 110 dias até o amadurecimento, e as médias, 110 a 140 dias. Quando as médias diárias são inferiores àquele valor, o período para amadurecimento estende-se por 10 a 20 dias para cada $0,5^{\circ} \mathrm{C}$ de diminuição da temperatura de acordo com a variedade. Estes autores apresentam os valores de $\mathrm{Kc}$ e do nível de esgotamento da água do solo para o milho. conforme o Quadro 01. 
Segundo eles, rendimentos da ordem de 6 a 9 t/ha (10 a $13 \%$ de umidade) são considerados bons comercialmente.

Quadro 01 - Valores de Kc e Percentual de Esgotamento para o Milho

\begin{tabular}{lccc}
\multicolumn{1}{c}{ FASE } & DURAÇÃO (dias) & Kc & Esgotamento \\
\hline ESTABELECIMENTO & $15-25$ & $0,3-0,5$ & $40 \%$ \\
VEGETATIVA & $25-40$ & $0,7-0,85$ & $55-65 \%$ \\
FLORAÇ̃̃O* $^{*}$ & $15-20$ & $1,05-1,2$ & $55-65 \%$ \\
FORMAÇÃO DA COLHEITA* & $35-45$ & $0,8-0,9$ & $55-65 \%$ \\
MATURAÇÃO & $10-15$ & $0,55-0,6$ & $80 \%$ \\
\hline
\end{tabular}

* Períodos Críticos em que deve-se evitar défices hídricos

\section{3- Intercepção da Precipitação pela Cultura do Milho}

A hidrologia aborda a intercepção foliar da água de chuva estimando pela equação $x=a+b . t$ as perdas por ela acarretadas ( $x=$ intercepção total em mm; $a=$ capacidade de acumulação por intercepção; $b=$ taxa de evaporação $\mathrm{em} \mathrm{mm} / \mathrm{h}$ durante $a$ chuva e $\mathrm{t}$ =duração da chuva em horas). As perdas aumentam com a duração da precipitação e seu valor percentual decresce com o aumento da lâmina precipitada (Wisler \& Brater,1964).

Segundo Steiner et al (1983) a água retida contribui para reduzir a transpiração das plantas enquanto evapora, não podendo então ser considerada toda como perda.

Segundo Silva (1993) são poucos os trabalhos com intercepção foliar por culturas anuais. O milho é uma cultura em que tal estudo parece ser particularmente interessante devido ao formato de suas folhas. Talvez devido a isso a maioria dos poucos trabalhos realizados se refiram a esta cultura. 
Steiner et al (1983), partindo de dados de 16 aplicações de água em lâminas entre 19 e $42 \mathrm{~mm}$, observou que cerca de metade da água que atinge o solo sob uma lavoura de milho completamente desenvolvida (IAF $>3$ ) o faz escorrendo pelo colmo, e que as plantas retêm assim 2,7 mm de água na bainha de suas folhas. Pessoa (1994) encontrou valores de retenção foliar entre 1,1 e 2,6 mm de lâmina d'água em diferentes fases do ciclo do milho com diferentes emissores em pivô central, trabalhando com lâminas entre 6,5 e $26,8 \mathrm{~mm}$.

Kelso \& Gilley (1986) encontraram os seguintes valores de retenção foliar sob pivô central: $8,1 \mathrm{~mm}$ para lâmina de $30,2 \mathrm{~mm}$ (aspersores rotativos de baixa pressão) $8,1 \mathrm{~mm}$ para lâmina de $35,8 \mathrm{~mm}$ (aspersores rotativos de alta pressão) e $1,7 \mathrm{~mm}$ para lâmina bruta de $28,4 \mathrm{~mm}$ (difusores de baixa pressão) sempre com a cultura de milho no início do pendoamento.

Silva (1993) encontrou que, após o estabelecimento da cultura do milho, chuvas menores ou iguais a $1,0 \mathrm{~mm}$ eram interceptadas integralmente. $\grave{A}$ medida em que ocorriam chuvas maiores o percentual de intercepção diminuía, sendo de $8,7 \mathrm{~mm}$ (24,2\%) para uma precipitação de $36,0 \mathrm{~mm}$. Miranda \& Butler (1986) e Rao (1987) afirmam que nas regiões temperadas, onde a precipitação anual é em torno de $700 \mathrm{~mm}$, a intercepção foliar pode atingir $70 \%$ do total precipitado.

Uma vez que a intercepção é significativa, nada mais justo que concluir que também a uniformidade com que a água é distribuída por aspersores seja alterada pela parte aérea dos vegetais. 
Saffigna et al (1976) relatam tal fato em cultura de batatas. Segundo eles, a desuniformidade provocada pela parte aérea aumenta a lixiviação de defensivos e adubos, trazendo prejuízos ambientais e econômicos. Em suas observações perceberam que 20 a $46 \%$ da água de irrigação e 4 a $23 \%$ da água de chuva atingiam o solo escorrendo pelo caule das plantas de batata, e mesmo 2 dias após uma chuva o solo abaixo das plantas ainda continha na camada superficial o dobro de umidade que o solo das entrelinhas (espaçamento de $0,31 \times 0,92 \mathrm{~m}$, solo arenoso). Em suas conclusões, sugerem que tal perfil de distribuição fosse considerado no manejo de fertilizantes e irrigação.

Este mesmo autor cita Kiesselbach (1916) ${ }^{1}$, segundo quem as folhas de uma planta de milho madura conduzem 3 litros de água pelo colmo para $25 \mathrm{~mm}$ de chuvas.

Ayars et al (1991) afirmam que a folhagem de uma cultura em crescimento tem significante potencial para alterar a uniformidade de distribuição da água aplicada na irrigação. Em vista disso, avaliaram a influência da parte aérea do algodoeiro sobre a uniformidade de distribuição de água por um sistema lateral móvel medindo-a acima e abaixo do dossel. Cinco uniformidades de distribuição com dois diferentes comprimentos de onda e duas lâminas foram testadas, e o CUC foi incrementado pela folhagem. A posição das folhas do algodoeiro (aproximadamente paralelas ao solo) parece ser responsável por este efeito, mais significativo à medida em que se aumentou a

\footnotetext{
${ }^{1}$ KIESSELBACH, T.A. Transpiration as a factor in crop production. Univ. Neb. Agric. Exp. Stn., Res. Bull. 6. 214 p. 1916
} 
lâmina de irrigação, exceto no caso do tratamento com $\mathrm{CUC}=90 \%$. Observou-se efeito da baixa uniformidade sobre o desenvolvimento da parte aérea do algodoeiro.

Segundo Conte \& Leopoldo (1986), as perdas por intercepção devem ser consideradas no caso de culturas anuais irrigadas por aspersão, "uma vez que elas interferem no coeficiente de uniformidade e eficiência de irrigação, alterando-os em função do desenvolvimento da cultura". Em 30 leituras feitas em lavoura de milho entre 06/01 e 22/04/86 encontraram que da lâmina total precipitada ao longo de todo o ciclo, $69,7 \%$ caíram entre as folhas (precipitação interna) e 22,2\% escoaram pelo colmo, com perda portanto de $8,1 \%$ por interceptação. Estes autores afirmam que, no caso de culturas anuais, as perdas por intercepção devem ser consideradas.

Leopoldo et al (1981) afirmam que em culturas anuais a intercepção é estreitamente relacionada à idade da cultura através da cobertura do solo pelas folhas, que cresce até dado ponto e cai a partir da maturação. Estes autores apresentam as definições básicas de estudos a respeito: precipitação total (Pt) é a quantidade de água que é precipitada no sistema; precipitação interna ( $\mathrm{Pi}$ ) é a que chega ao solo por entre as folhas; escoamento pelo tronco (Et) é a que chega ao solo escoando-se pelo caule do vegetal (no presente trabalho referida como Ec - escoamento pelo colmo) e perda por intercepção (I) é a que se perde para a atmosfera por evaporação após ser retida pelas folhas. Encontraram valor de 4,1\% para I e 39\% para Ec em cana de açúcar. A Pi foi relacionada com o ciclo da cana de açúcar (Leopoldo et al,1981) e do milho (Conte \& 
Leopoldo,1986) pelas equações do segundo grau abaixo ( $Y=$ precipitação interna em percentual e $\mathrm{X}=$ dias após plantio).

$$
\begin{gathered}
Y=235,31-1,68 X+0,0034 X^{2} \text { (cana de açúcar) } \\
Y=153,12-2,08 X+0,01105 X^{2} \text { (milho) } r^{2}=0,63
\end{gathered}
$$

Para o escoamento pelo colmo do milho (Ec) a melhor correlação foi obtida também com a idade da cultura e através do modelo exponencial, com coeficiente de correlação de -0,7218:

$$
\mathrm{Ec}=75,83 \cdot \mathrm{e}^{-0,0138} \bullet
$$

Aqueles dados por si só dão a entender a baixa uniformidade causada pela parte aérea. Uma vez que a linha de plantio da cana (para onde se destina a água escoada pelo colmo) ocupa menos que $20 \%$ da área plantada, estará recebendo pelo menos o dobro da água que deveria ( $39 \%$ da precipitação), em prejuízo da área entre linhas. Da mesma forma, a linha de semeadura de milho também ocupa bem menos que $22,2 \%$ da área total, mas recebe diretamente esse percentual da água precipitada. Simultaneamente, o fato de o espaçamento entre plantas na linha e o espaçamento entre linhas serem significativamente diferentes no caso do milho, há que se prever que a uniformidade de distribuição seja diferentemente alterada na linha e na entrelinha.

Trabalhos que abordem esta questão, no entanto, são poucos, e os que foram feitos não se dedicaram a investigar a relação de tais valores (de precipitação interna e escoamento pelo colmo) com a uniformidade de precipitação.

O termo "precipitação efetiva" é definido pela FAO como "a porção da precipitação utilizada direta ou indiretamente para a produção vegetal no local onde foi 
precipitada, sem bombeamento. Inclui assim a água interceptada, a evaporada da superficie do solo, a evapotranspirada, a que contribui para necessária lixiviação de sais ou facilita qualquer trato cultural anterior ou posterior à aração sem causar perda de produção ou qualidade da cultura principal" (Dastane, 1974). Neste trabalho, no entanto, será entendida como a porção do total precipitado que efetivamente chega ao solo, ou seja: o somatório de Ec e Pi, conforme usado por Leopoldo et al (1981). 


\section{MATERIAL E MÉTODOS:}

O ensaio foi realizado na Fazenda Areão, Piracicaba, SP, cujas coordenadas geográficas são $22^{\circ} 43^{\prime} \mathrm{S}$ de latitude e $47^{0} 38^{\prime} \mathrm{W}$ de longitude. O solo da área utilizada é classificado como Terra Roxa Estruturada, série Luiz de Queiroz com declividade de $7 \%$.

\section{1- Condução da Cultura}

O milho foi semeado acompanhando as curvas de nível em 10 de abril de 1995 numa área de $90 \times 25$ metros, após o adequado preparo do solo. $\mathrm{O}$ espaçamento usado foi de 0,9 metros entre linhas com média de 6 plantas por metro. $O$ híbrido utilizado foi o ZENECA 8372 e a adubação conforme a análise química de solo.

O controle de ervas daninhas foi feito por herbicidas aplicados mecanicamente. Algumas espécies resistentes (Panicum maximum, entre outras) promoveram infestações localizadas e tiveram sua população controlada por arranquio manual, e outras (Cyperus $s p p$ ) pelo próprio sombreamento pela cultura. 
Aos 30 dias da semeadura foi feita a adubação de cobertura com $50 \mathrm{~kg} \mathrm{~N} / \mathrm{ha}$ utilizando-se como fonte o formulado 20-05-20.

Foram detectados leves danos pela presença de lagarta rosca e lagarta elasmo. Contra os ataques da Lagarta do Cartucho foram realizadas pulverizações quinzenais desde a constatação da necessidade do controle até o início do pendoamento.

\section{2- Irrigação}

O sistema de irrigação (Figura 1) foi constituído por duas tubulações paralelas com 12 aspersores, cada conjunto de quatro delimitando parcelas com três diferentes espaçamentos: $6 \times 12 \mathrm{~m}, 12 \times 18 \mathrm{~m}$ e $18 \times 18 \mathrm{~m}$ que possibilitaram três níveis de uniformidade de distribuição representados pelos coeficientes de uniformidade de christiansen de $89 \%, 73 \%$ e $62 \%$ (referidos como alta, média e baixa uniformidades), determinados no campo, após a instalação do sistema. Entre cada duas parcelas foi deixado uma bordadura de $18 \mathrm{~m}$.

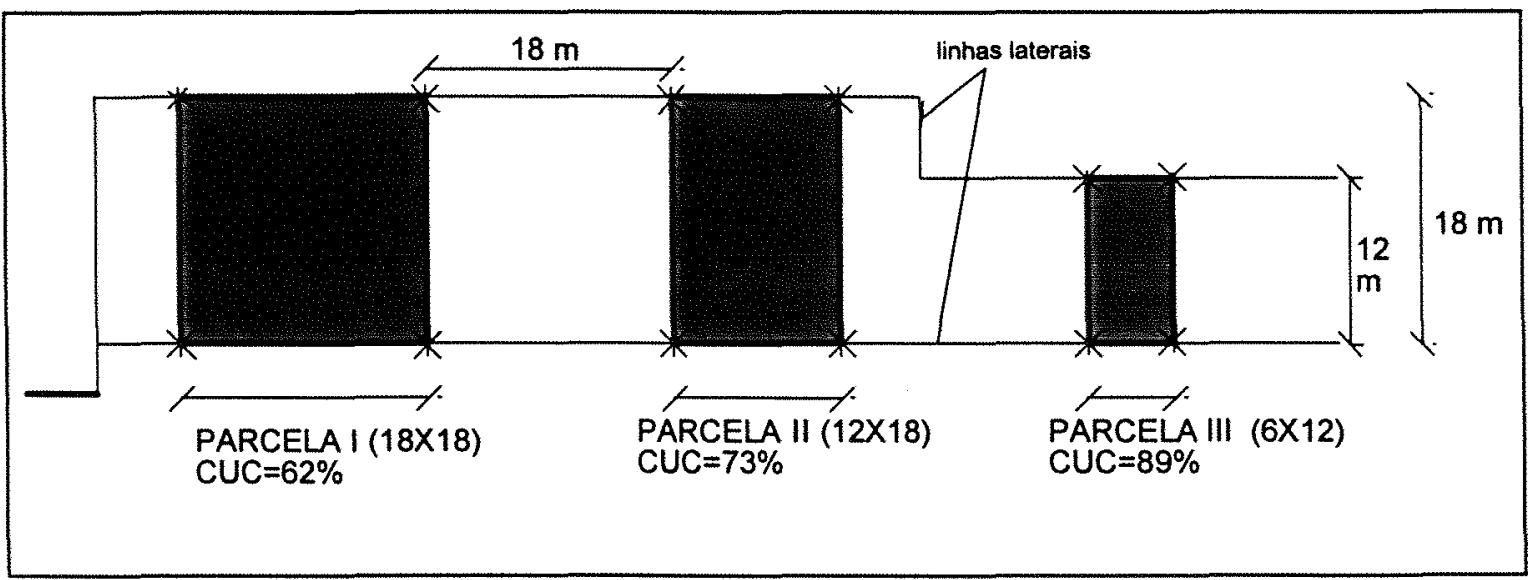

Figura 1- Esquema da tubulação com os aspersores. 
O manejo da irrigação foi feito baseado nas leituras diárias de evaporação no tanque classe A e de precipitação em pluviômetro ambos da Estação Climatológica da ESALQ. Aos 143 dias da semeadura (soma térmica $\cong 1455$ ) foi realizada a última irrigação, com os grãos já bem próximos da completa maturação.

Os aspersores utilizados foram da marca FABRIMAR, modelo A1823, bocais $2,4 \times 3,2 \mathrm{~mm}$, cujas características operacionais são apresentadas no Quadro 02. Nos espaçamentos em que se desejou média e baixa uniformidades (CUC=62 e $73 \%$ ) foram retirados os turbilhonadores de fluxo dos bocais auxiliares dos aspersores.

A verificação da pressão de operação (250 $\mathrm{kPa}$ no bocal dos aspersores) foi feita através de manômetro conectado às linhas laterais, e sua adequação foi obtida fazendo-se uso da válvula de derivação.

Quadro 02- Características operacionais do aspersor FABRIMAR A1823 segundo catálogo do fabricante

\begin{tabular}{cccccc}
\hline $\begin{array}{c}\text { bocais } \\
(\mathrm{mm})\end{array}$ & $\begin{array}{c}\text { pressão } \\
\text { de serviço }\end{array}$ & $\begin{array}{c}\text { vazão total } \\
\left(\mathrm{m}^{3} / \mathrm{h}\right)\end{array}$ & $\begin{array}{c}\text { diâmetro } \\
\text { molhado }(\mathrm{m})\end{array}$ & $\begin{array}{c}\text { espaçamento } \\
(\mathrm{m} \times \mathrm{m})\end{array}$ & $\begin{array}{c}\text { precipitação } \\
(\mathrm{mm} / \mathrm{h})\end{array}$ \\
\hline \multirow{3}{*}{$2,4 \times 3,2$} & $20 \mathrm{mca}$ & 0,85 & 24 & $12 \times 18$ & 3,94 \\
& $\mathbf{2 5} \mathbf{~ m c a}$ & $\mathbf{0 , 9 6}$ & $\mathbf{2 4}$ & $\mathbf{1 2} \times \mathbf{1 8}$ & $\mathbf{4 , 4 4}$ \\
& $30 \mathrm{mca}$ & 1,06 & 25 & $12 \times 18$ & 4,91 \\
& $35 \mathrm{mca}$ & 1,14 & 25 & $18 \times 18$ & 3,52 \\
\hline
\end{tabular}

*condição utilizada no trabalho

\section{3- Estimativa da Uniformidade de Distribuição}

Os coletores (metálicos, com diâmetro de $10,5 \mathrm{~cm}$ ) foram instalados logo após a semeadura a $30 \mathrm{~cm}$ de altura em relação ao solo em um espaçamento não múltiplo do espaçamento da cultura, de forma que ficassem em diferentes posições relativas às linhas 
de semeadura (coletores a 15, 45 e $75 \mathrm{~cm}$ da linha, conforme Figura 2). Para tanto foi usado o espaçamento de $1,20 \mathrm{~m} \times 1,20 \mathrm{~m}$ para a parcela $\mathrm{I}$, e $2,40 \mathrm{~m} \times 2,40 \mathrm{~m}$ nas demais, o que resultou em um número de 64,40 e 50 coletores, respectivamente, nas parcelas de baixa, média e alta uniformidades. Os testes foram feitos em horário com o mínimo de velocidade de vento e baixa temperatura. A velocidade do vento durante os testes foi medida a partir do dia 21/07/96 (vide apêndice 5).

Obtidas as leituras de volume coletado, estimou-se o CUC fornecido pelo equipamento, inicialmente sem influência da cultura (observações testemunha) e, de acordo com o desenvolvimento das plantas, com influência crescente das mesmas.

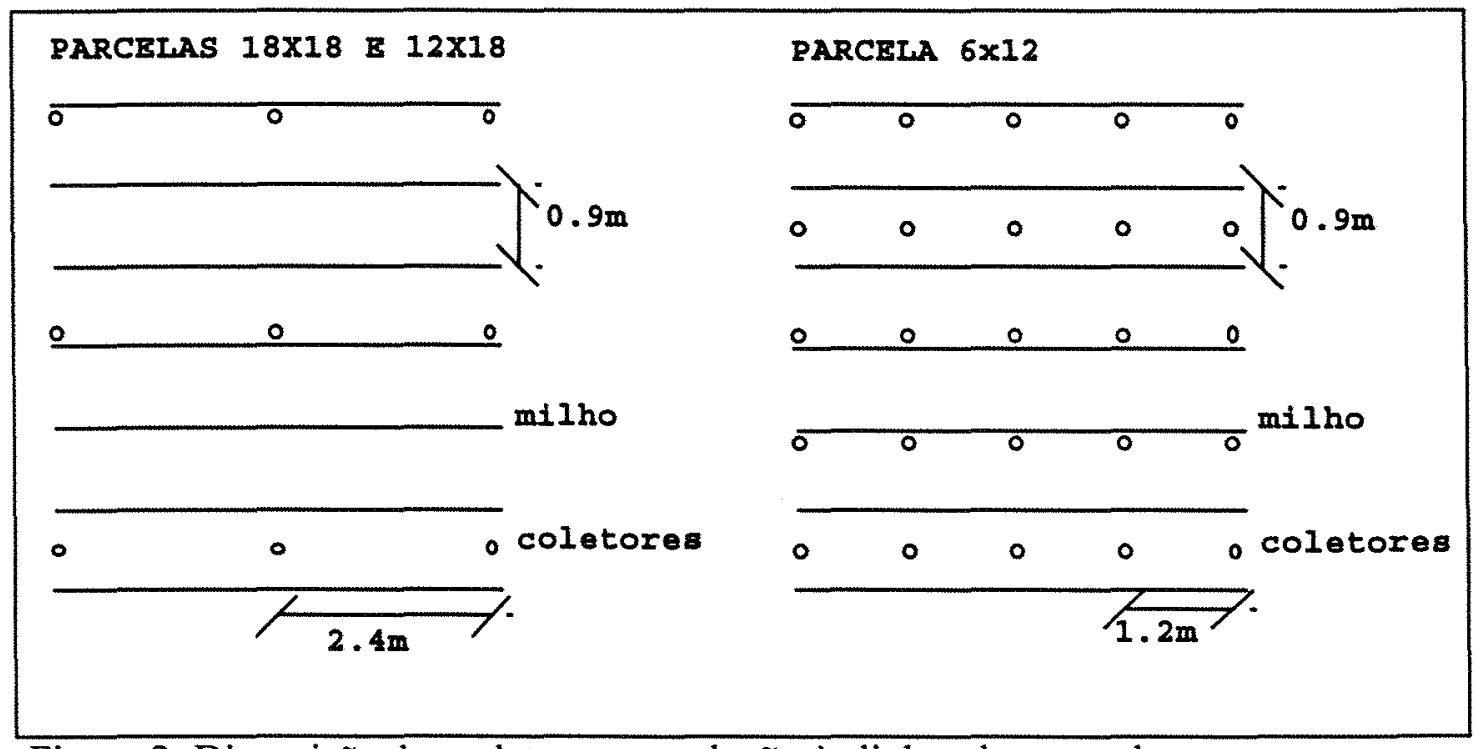

Figura 2: Disposição dos coletores em relação às linhas de semeadura 


\section{4- Precipitação Interna e Escoamento pelo Colmo}

A disposição dos coletores em relação às linhas de semeadura e o uso de coletores adaptados ao colmo das plantas a partir do dia 17/07/96 permitiu que se representasse a precipitação interna com a cultura adulta na forma de um perfil traçado a partir de amostras coletadas a 0 (colmo), 15,45 e $75 \mathrm{~cm}$ das linhas de semeadura.

Para coleta da água escoada pelo colmo (Ec) foram utilizados copos plásticos de $200 \mathrm{~cm}^{3}$ cortados na metade de sua altura (diâmetro aproximado de $5 \mathrm{~cm}$ ) ao fundo dos quais foi adaptada previamente uma mangueira plástica transparente (diâmetro interno aproximado de $2 \mathrm{~mm}$ ), utilizando-se para tanto massa de soldar DUREPOXI. Uma vez no campo, os copos foram cortados no fundo de forma a envolverem o colmo das plantas às quais seriam adaptados. Esta adaptação foi feita com o uso de massa de calafetar (Figura 3). A mangueira foi então ligada a garrafas plásticas de 2 litros, tampadas e com saída de ar para coleta da água. Após cada irrigação todos os coletores assim montados eram verificados quanto a vazamentos e reparados ou substituídos conforme a necessidade.

Em relação ao cálculo do valor de Ec, foi utilizado o seguinte procedimento:

a) os copos foram adaptados em plantas próximas a uma determinada coluna de coletores metálicos onde o volume percentual coletado em relação à média nos testes na ausência de cultura foi aproximadamente constante; 
b) o volume médio de água aplicado por planta foi calculado e corrigido para a coluna em questão pelo fator percentual determinado no item anterior;

c) o volume escoado pelo colmo foi medido e expresso como percentual do volume aplicado por planta.

Tal procedimento, assim como os valores obtidos, encontram-se no APÊNDICE 1.
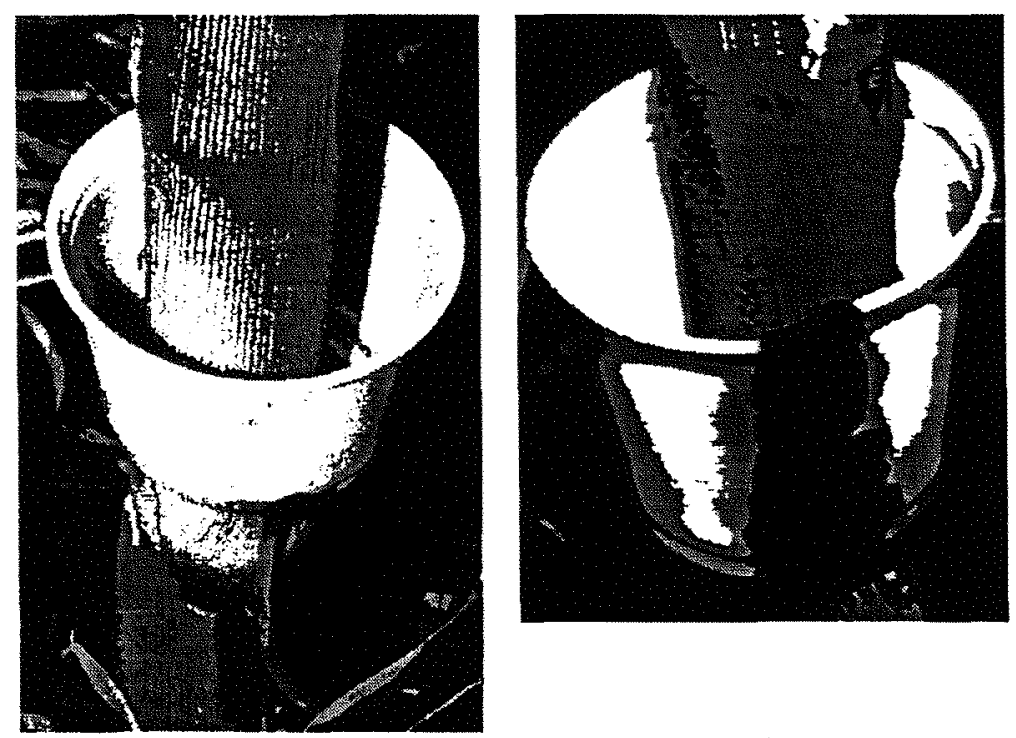

Figura 3 - Coletores de Escoamento pelo Colmo

\section{5- Desenvolvimento da Cultura}

A descrição do desenvolvimento da cultura foi feita pela determinação do seu Índice de Área Foliar (IAF). Para tanto foram selecionadas, em cada parcela, 5 plantas representativas cuja área foliar (área foliar $=\Sigma($ comprimento . largura máxima. $\mathbf{0 , 7 5})$, segundo Endres \& Mundstock, 1989 ) foi determinada pelo método não destrutivo com 
intervalo entre medidas nunca superior a 15 dias. Uma vez que tal determinação não visa observar a capacidade fotossintetizante das plantas, não se considerou o fato de as folhas estarem verdes ou secas. A eliminação de uma folha da contagem ocorria somente após seu tombamento, quando então não estava mais influenciando a trajetória das gotas até o solo.

Na parcela III uma das plantas foi desconsiderada a partir de certa data, em vista de ter tido o crescimento de suas folhas alterado por intoxicação química.

Outras formas utilizadas para expressar o desenvolvimento da cultura foram a soma térmica, a idade em dias e a denominação dos diversos estádios do ciclo. A soma térmica foi calculada por:

$$
\text { resultado diario }=\frac{\text { Temp. Maxima }+ \text { Temp. Minima }}{2}-10
$$




\section{RESULTADOS E DISCUSSÃO:}

\section{1- Desenvolvimento da Cultura}

Semeada aos 10 dias de abril de 1996, a cultura teve seu desenvolvimento retardado pelas condições climáticas do inverno (baixa temperatura ) e pelo uso da própria irrigação, conforme foi relatado também por Costa et al (1992). A determinação da duração das diversas fases do ciclo, para efeito do manejo da irrigação, foi feita visualmente pelo aspecto da cultura conforme o seguinte critério: Fase 0 (estabelecimento): da semeadura até os 30 dias; Fase 1 (vegetativa): dos 30 dias até o pendoamento; Fase 2 (reprodutiva): do pendoamento até o início do endurecimento dos grãos; Fase 3 (amadurecimento): até a cessação da irrigação. Assim é que a fase 0 foi até os 30 dias, a fase 1 até os 85 dias, a 2 até os 118 e a 3 até os 143 dias. A colheita ocorreu aos 164 dias (21/09), com os grãos com cerca de $20 \%$ de umidade, os quais foram pesados após secos em terreiro até 13\% de umidade, determinando-se os rendimentos de $6972 \mathrm{~kg} / \mathrm{ha}, 6861 \mathrm{~kg} / \mathrm{ha}$ e $6305 \mathrm{~kg} / \mathrm{ha}$ para as parcelas com alta, média e baixa uniformidades de distribuição de água. A evolução do índice de área foliar e da altura média das plantas nas três parcelas em relação à soma térmica ocorreu conforme 
pode ser observado na Figura 4. O rendimento de grãos em função de CUC está representado na Figura 5. A parcela I teve como densidade final 6 plantas $/ \mathrm{m}^{2}$, a parcela II, 5,8 plantas $/ \mathrm{m}^{2}$ e a parcela III, 6,2 plantas $/ \mathrm{m}^{2}$.

No APÊNDICE 2 são apresentadas as condições climáticas do período do experimento e o cálculo da soma térmica. No APÊNDICE 3 o acompanhamento do desenvolvimento das plantas (soma térmica, altura das plantas e IAF ) e, no APÊNDICE 4 o manejo da irrigação pelo método do tanque "Classe A".
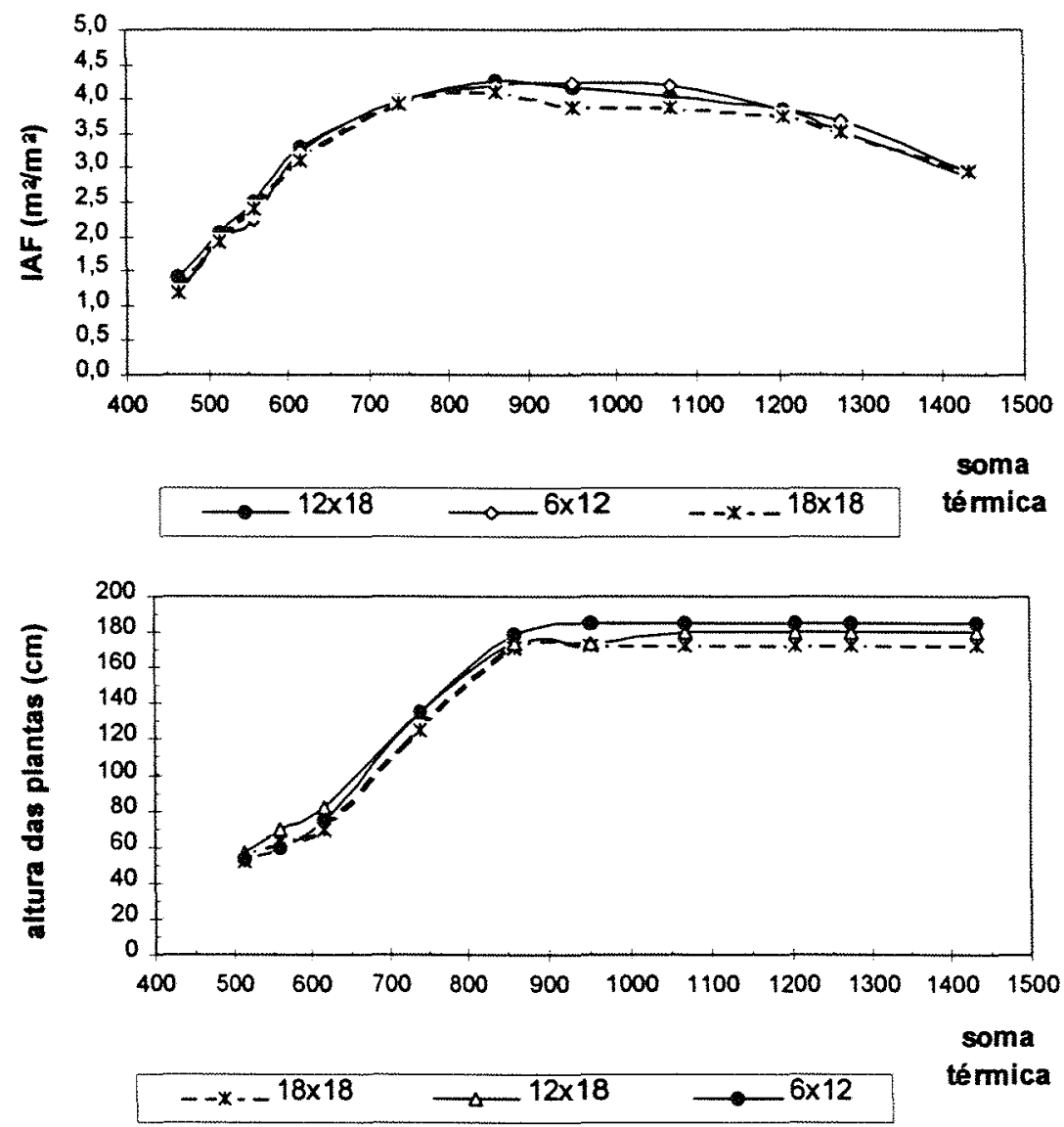

Figura 4- IAF e altura das plantas em função da soma térmica para as três parcelas 


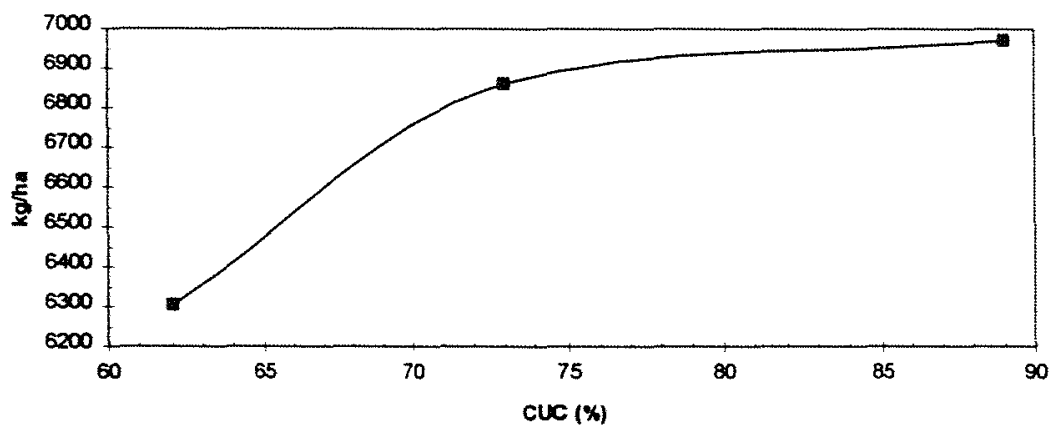

Figura 5- Rendimento em função do CUC de Distribuição

\section{2- Uniformidade de Irrigação}

Os resultados dos testes de uniformidade e o cálculo do CUC e lâmina aplicada estão no APÊNDICE 5.

O coeficiente de uniformidade de christiansen (CUC) e a precipitação interna ( $\mathrm{Pi}$ ) medidos sob a influência da cultura variaram durante o desenvolvimento da cultura, tendo sido relacionados com a soma térmica através de polinômios do $2^{\ell}$ grau. Isto pode ser observado nas Figuras 6 e 7 e no Quadro 03.

Não foi possível correlacionar CUC e Pi com o IAF. O que ocorre é que há sempre duas situações distintas com o mesmo valor do índice: uma no crescimento e outra na senescência da cultura, ambas influindo diferentemente sobre o CUC e precipitação interna. Durante o crescimento, a área foliar é predominantemente composta pelas folhas baixas, enquanto na senescência são as altas que a compõem.

Em vista disso, o fator 'soma térmica' torna-se o mais adequado para correlação com o CUC e Pi, por diferenciar o crescimento e senescência das plantas ao mesmo 
tempo em que torna as conclusões obtidas extrapoláveis para outras condições de trabalho. Leopoldo et al (1981) e Conte \& Leopoldo (1986) correlacionaram Pi com o fator Idade da Cultura. Uma vez que o desenvolvimento das plantas não é função de sua idade, mas sim da energia disponível, torna-se difícil a aplicação dos resultados apresentados por estes autores a plantios em condições climáticas diferentes daquelas sob as quais fizeram suas observações.

Quadro 03 - Resumo dos resultados dos testes de uniformidade

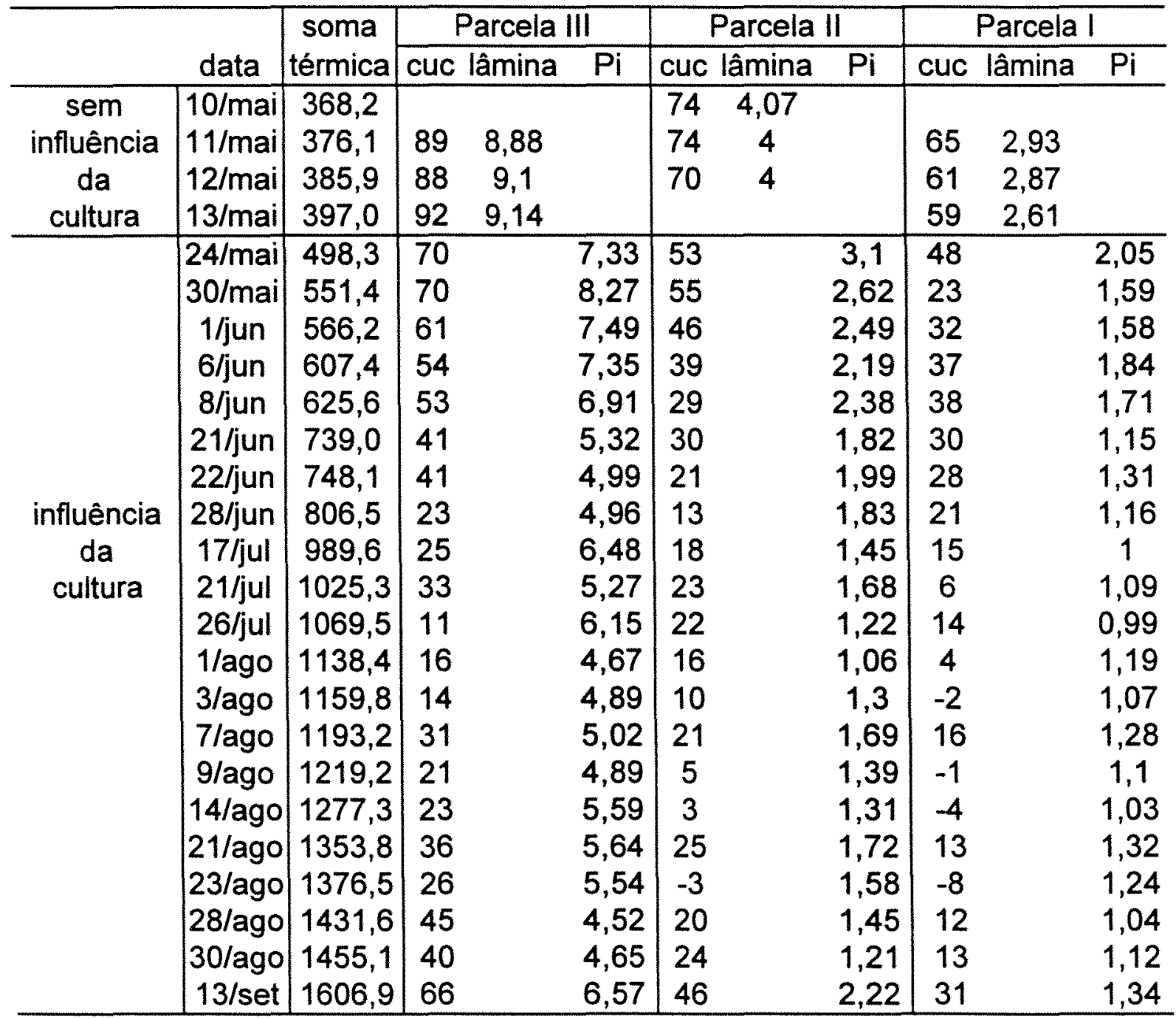




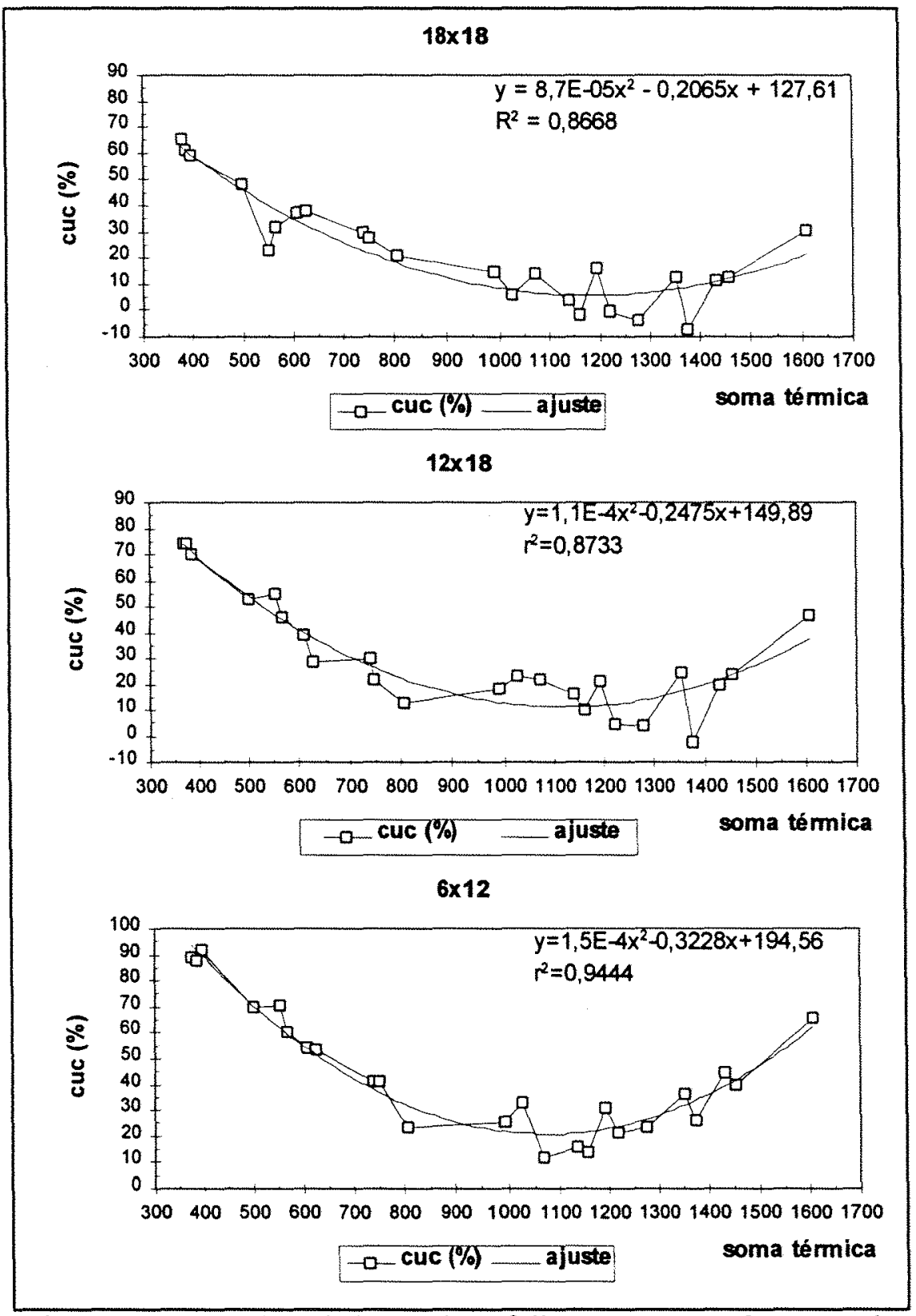

Figura 6- CUC abaixo da folhagem em função do desenvolvimento da cultura 


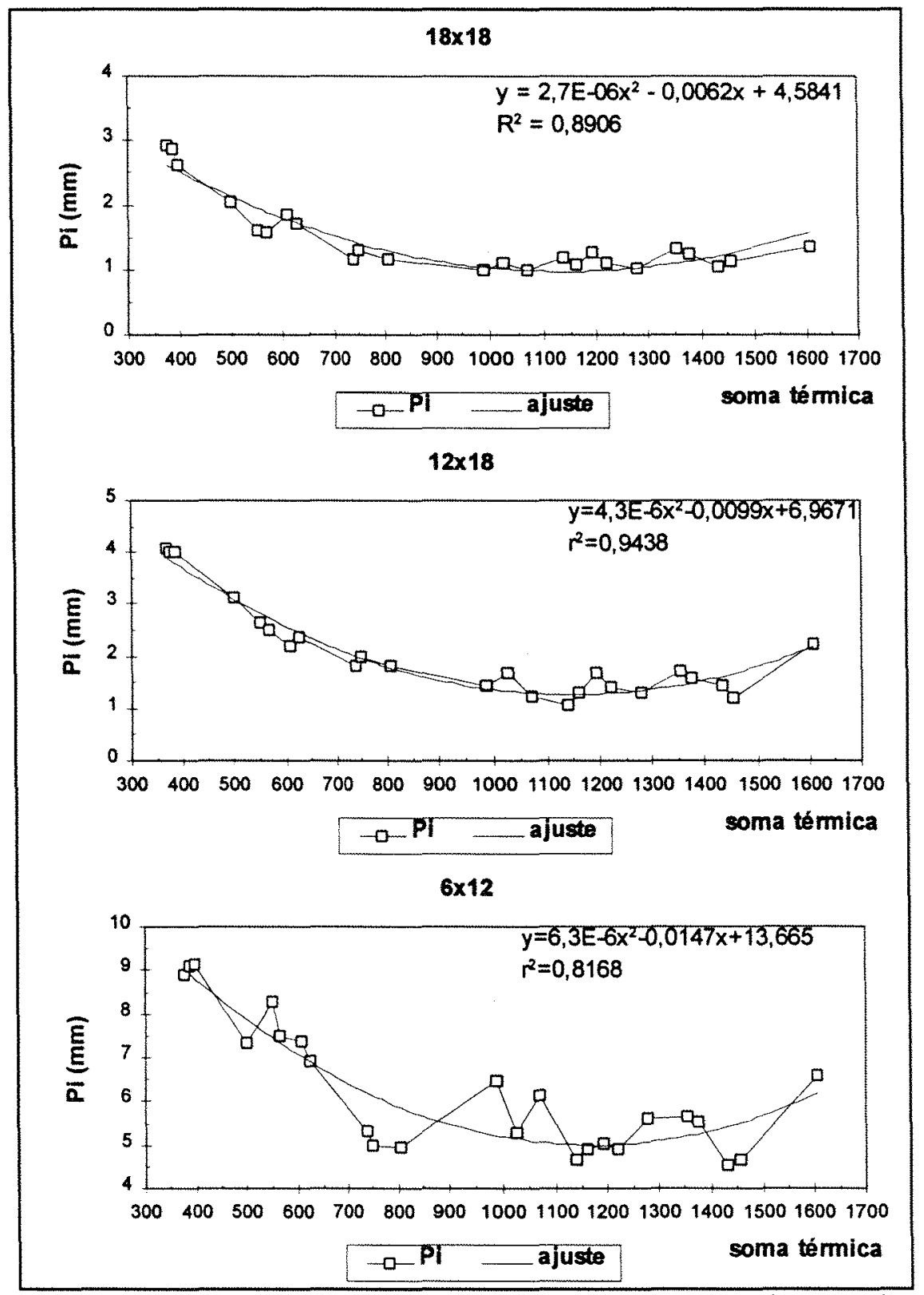

Figura 7- Precipitação interna em função do desenvolvimento da cultura 


\section{3- Escoamento pelo Colmo e Precipitação Interna}

Os valores da precipitação interna $(\mathrm{Pi})$ e escoamento pelo colmo $(\mathrm{Ec})$ em relação à precipitação efetiva $(\mathrm{PE})$ encontram-se no APÊNDICE 6.

$\mathrm{O}$ escoamento pelo colmo $(\mathrm{Ec})$ foi medido no período de 17 de julho (soma térmica $=990$ ) a 30 de agosto (última irrigação, soma térmica $=1455$ ). Seu valor oscilou ao redor da média de $31,5 \%$ da precipitação total para a parcela I, 33,5\% para a parcela II e $36,8 \%$ para a parcela III. A relativa constância do valor de Ec/Pt enquanto o número de folhas por planta decresce indica que as folhas superiores são as principais responsáveis pelo desvio da água em direção ao colmo. O valor de Ec começou a cair quando se chegou a 6 folhas por planta, ocasião em que cessaram as medidas de IAF em vista de estarem praticamente todas as folhas secas.

Os valores médios de $\mathrm{Ec} / \mathrm{Pt}$ demonstram seu aumento com a precipitação(mm), conforme se observa na Figura 8, com a qual se relacionou linearmente no período observado.

A precipitação interna durante este mesmo período (soma térmica $=990$ a 1455), oscilou em torno da média de $38,10 \%$ da precipitação total para a parcela I, 36,09\% para

a II e 61,58/para a III. Observa-se novamente aqui a tendência de aumento com a precipitação, mais intensamente no entanto entre as parcelas II e III, conforme a Figura 8. 
$\mathrm{O}$ crescimento simultâneo de $\mathrm{Ec}$ e $\mathrm{Pi}$, em relação à precipitação total $(\mathrm{Pt})$, reflete na verdade a diminuição das perdas por intercepção pelas folhas com o aumento da precipitação. Tal fenômeno era esperado, uma vez que a capacidade de armazenamento da parte aérea de uma lavoura de milho adulta é limitada, o que faz com que a participação percentual deste armazenamento no balanço da água precipitada seja decrescente com a quantidade aplicada.

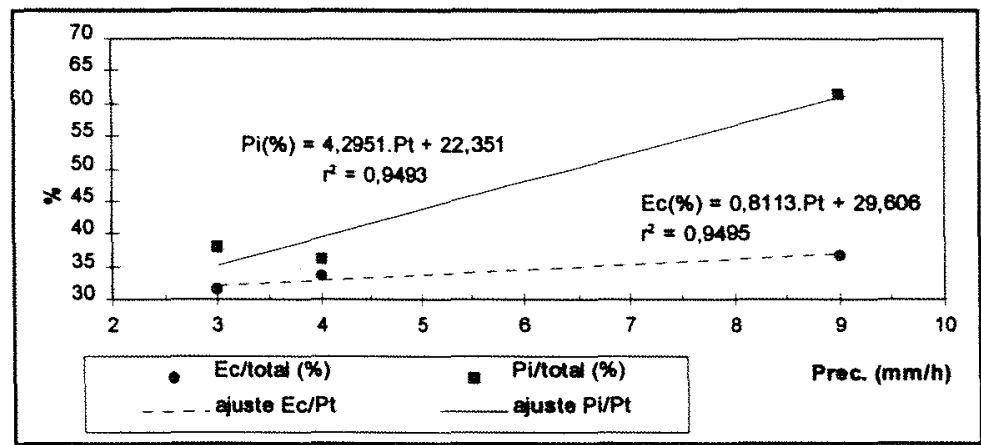

Figura 8- Escoamento pelo colmo e precipitação interna em função da precipitação total

Em relação à precipitação efetiva $(\mathrm{PE}=\mathrm{Ec}+\mathrm{Pi})$, a participação percentual de $\mathrm{Ec}$ até o fim da fase de amadurecimento (soma térmica $=1455$ ) foi em média de 44,5 e $50,0 \%$ nas parcelas I e II, e de $38,8 \%$ na parcela III, conforme se observa na Figura 9. Tal resultado se aproxima do obtido por Steiner et al (1983), segundo quem o valor de Ec para lavouras de milho com IAF $>3 \mathrm{~m}^{2} / \mathrm{m}^{2}$ é de $45 \%$ da PE.

Os resultados indicam que uma maior intensidade de precipitação (parcela III) favorece mais a precipitação interna que o escoamento pelo colmo.

O aumento de Pi observado em 13/09 foi ocasionado pela senescência da cultura cuja colheita ocorreria 8 dias após aquele teste. 


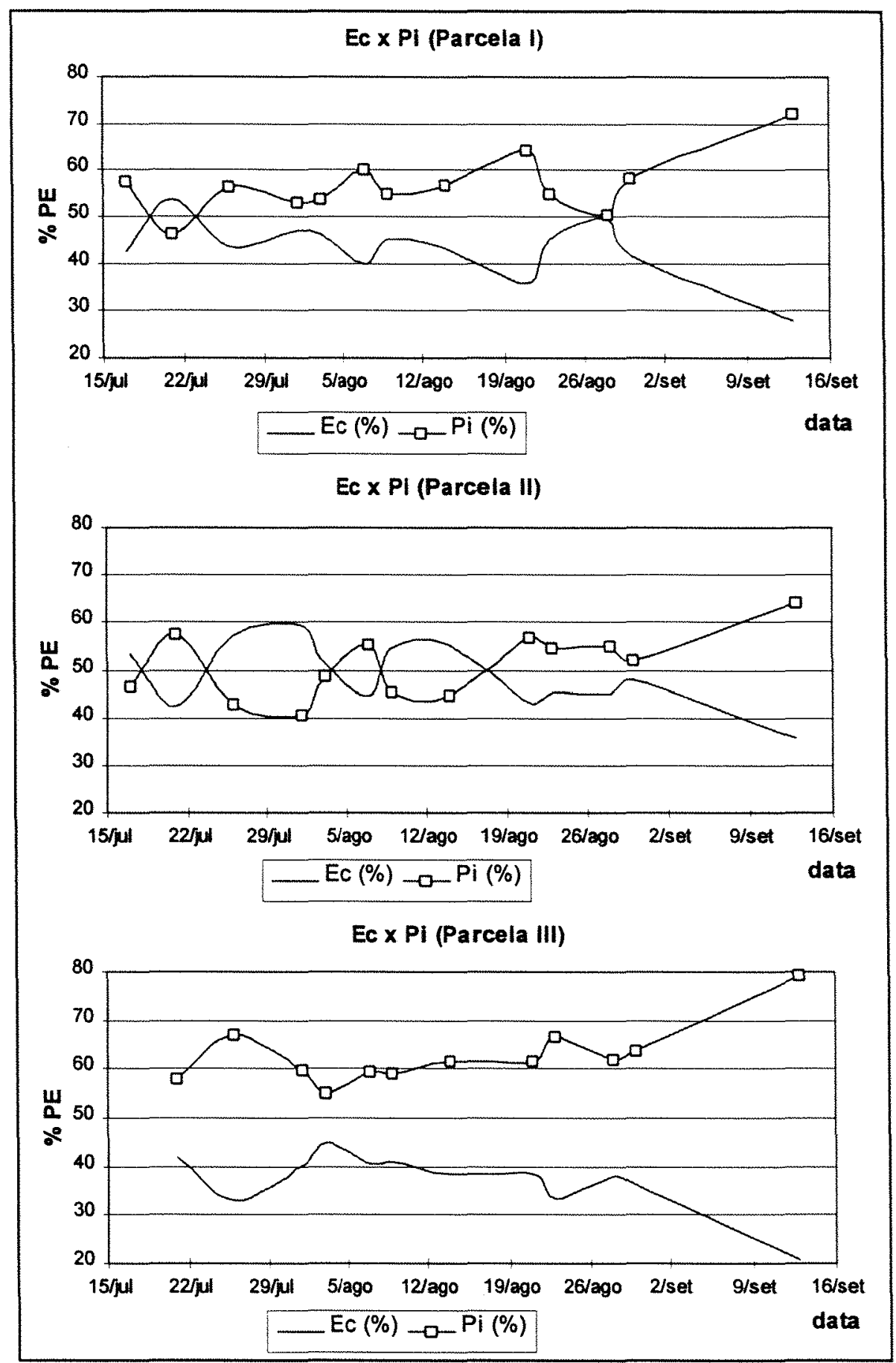

Figura 9- Escoamento pelo colmo e precipitação interna em relação à precipitação efetiva para as três parcelas 


\section{4- Perfil de Distribuição da Água Através das Entrelinhas}

A distribuição dos coletores no campo foi feita de forma que se pudesse, ao final dos testes, proporcionalizar a precipitação interna conforme a distância da linha de semeadura, com vistas a verificar uma possível concentração da água no centro da entrelinha.

A Pi se concentrou, durante as fases vegetativa, reprodutiva e de maturação, no centro da entrelinha, onde foram coletados em média 48,45 e $50 \%$ da precipitação interna nas parcelas I, II e III respectivamente. Tal concentração foi mais evidente na fase reprodutiva, durante a qual as plantas já haviam atingido a altura máxima e o IAF se manteve em valores entre 3,76 e 4,26. O restante da $\mathrm{Pi}$ foi dividido de forma aproximadamente equilibrada nas posições a 15 e $75 \mathrm{~cm}$ da linha de plantio. Tal distribuição não se manteve após a maturação, tendendo a haver equilíbrio entre os volumes coletados nas três posições (Quadro 04).

Conjugando as informações do Quadro 04 com a divisão da Pe entre Ec e Pi, temos o perfil de aplicação, em percentual do volume total aplicado, apresentado aproximadamente como na Figura 10 e Quadro 05. Observa-se que entre as parcelas I e II há proximidade de valores, enquanto na parcela III o perfil já é bastante diferenciado. Nela, o aumento da intensidade de precipitação afetou pouco o percentual precipitado a 15 e $75 \mathrm{~cm}$ da linha de semeadura, mas diminuiu a amplitude da variação entre os volumes devidos ao $\mathrm{Ec}$ e à $\mathrm{Pi}$, aumentando o volume coletado no centro da entrelinha. 
Novos trabalhos, utilizando intensidades de precipitação maiores, são necessários para que se possa observar se haverá inversão da situação aqui descrita, com maior volume coletado no centro da entrelinha que ao pé das plantas.

Quadro 04: Divisão média da Pi (\%) por fase em relação à distância entre o coletor e a linha de semeadura

\begin{tabular}{c|ccc|c|cc}
\hline \multicolumn{7}{c}{$18 \times 18$} \\
\hline distância & vegetativa & reprodutiva & maturação & média & colheita & pós colheita \\
\hline $15 \mathrm{~cm}$ & 27,5 & 27,2 & 31,3 & 28,7 & 31,4 & 35,1 \\
$45 \mathrm{~cm}$ & 41,5 & 55,1 & 46,3 & 47,6 & 25,1 & 27,6 \\
$75 \mathrm{~cm}$ & 31,0 & 17,7 & 22,4 & 23,7 & 43,5 & 37,3 \\
\hline \multicolumn{7}{c}{$12 \times 18$} \\
\hline distância & vegetativa & reprodutiva & maturação & média & colheita & pós colheita \\
\hline $15 \mathrm{~cm}$ & 21,9 & 33,3 & 36,0 & 30,4 & 16,7 & 36,2 \\
$45 \mathrm{~cm}$ & 45,4 & 48,7 & 40,9 & 45,0 & 35,6 & 28,4 \\
$75 \mathrm{~cm}$ & 32,7 & 18,0 & 23,1 & 24,6 & 47,7 & 35,4 \\
\hline \multicolumn{7}{c}{6 x 12 } \\
\hline distância & vegetativa & reprodutiva & maturação & média & colheita & pós colheita \\
\hline $15 \mathrm{~cm}$ & 26,4 & 26,9 & 28,5 & 27,3 & 33,4 & 32,5 \\
$45 \mathrm{~cm}$ & 47,7 & 53,3 & 49,6 & 50,2 & 38,8 & 33,6 \\
$75 \mathrm{~cm}$ & 26,0 & 20,0 & 21,9 & 22,7 & 27,8 & 33,9 \\
\hline
\end{tabular}

Quadro 05: Distribuição do volume aplicado conforme a distância da linha de plantio

\begin{tabular}{cccc}
\hline PosiçãolParcela & I & II & III \\
\hline $\mathbf{0 ~ c m ~ ( E c ) ~}$ & $44,5 \%$ & $50 \%$ & $38,8 \%$ \\
$\mathbf{1 5}$ & $15,9 \%$ & $15 \%$ & $16,7 \%$ \\
$\mathbf{4 5}$ & $26,4 \%$ & $22,5 \%$ & $30,6 \%$ \\
$\mathbf{7 5}$ & $13,2 \%$ & $12,5 \%$ & $13,9 \%$ \\
\hline
\end{tabular}



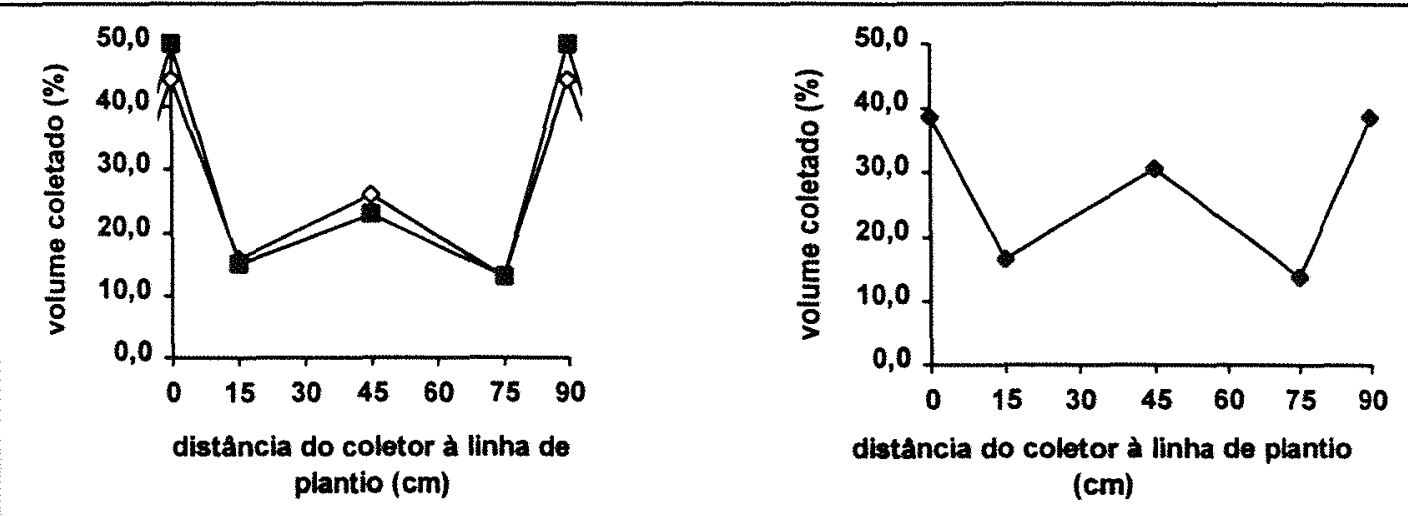

$\multimap$ Parcela 1

- Parcela II

- Parcela III

Figura 10- Perfil de distribuição da precipitação efetiva em relação à Precipitação total entre as linhas de semeadura

Tal observação pode ser importante quando se trabalha com quimigação. Sugere que, se for interessante a concentração da aplicação do produto no pé das plantas, devese usar baixas intensidades de aplicação. Em caso contrário, maiores intensidades diminuiriam tal concentração. A concentração de água na região próxima ao colmo, ao mesmo tempo em que garante a colocação do produto ao alcance da raiz, pode ser responsável por sua lixiviação e perda (no caso de adubos nitrogenados especialmente). Ao mesmo tempo, o uso de lâminas menores maximiza a retenção foliar, sendo interessante portanto em aplicações que visem as folhas, conforme relatou também Pessoa (1994).

Raciocínio semelhante poderá ser feito em relação à aplicação de defensivos agrícolas em outras culturas de acordo com o perfil de distribuição que ocasionem abaixo de sua folhagem. 
Deve-se considerar que, enquanto a Ec atinge o solo de maneira concentrada (alta intensidade), a Pi o faz esparsamente no tempo e no espaço (baixa intensidade). É difícil no entanto transformar o volume de Ec em lâmina. Qual seria a área de aplicação considerada? Leopoldo et al (1981), Steiner et al (1983) e Conte \& Leopoldo (1986) optaram por considerar a área ocupada pela folhagem da cultura, o que não expressa a taxa com que a água escoada pelo colmo atinge o solo. Apesar de ter sido coletado realmente por toda a superficie foliar, aquele volume terá atingido o solo quase pontualmente ao redor do colmo, se distribuindo no solo formando um "bulbo molhado". A determinação da área deste 'bulbo molhado' ao redor das plantas permitiria a expressão da quantidade de água aplicada na linha de plantio em forma de lâmina de irrigação. 


\section{CONCLUSÕES:}

- 45 e $50 \%$ da água que atinge o solo irrigado com lâminas de 3 e $4 \mathrm{~mm}$ o faz através do escoamento pelo colmo, produzindo, ao pé das plantas, alta intensidade de aplicação, sendo que maiores precipitações intensificaram o Ec.

- A precipitação interna é concentrada no centro da entrelinha, que recebe o dobro ou mais do volume que a região intermediária (entre a linha e o centro da entrelinha). O aumento da precipitação intensificou a Pi de maneira bem mais visivel que no caso do Ec.

- O aumento da intensidade de aplicação provocou uma menor participação de Ec e uma maior concentração de água no centro da entrelinha, pouco alterando o percentual que atingiu a região a 15 e $75 \mathrm{~cm}$ das linhas.

- Uma vez que a uniformidade com que a água atinge o solo é bem diferente daquela com que é distribuída pelo sistema, estudos de redistribuição, que visem uma utilização desta capacidade do solo como forma de reduzir custos de irrigação, devem partir de valores de CUC menores que os usuais. Sua realização na presença da cultura talvez seja o ideal, até mesmo porque outras culturas estarão alterando de forma diferente a uniformidade. 
- A consideração dos valores de Pi e Ec obtidos ao se planejar quimigações pode reduzir perdas e aumentar a eficiência das mesmas; inclusive através do manejo da lâmina aplicada, procurando concentrar ou não a aplicação na linha de semeadura e/ou maximizar ou não a retenção foliar.

- A parte aérea do milho diminui a uniformidade com que a água distribuída por sistemas de aspersão atinge o solo. A água aspergida por sistemas com CUC de 62,73 e $89 \%$ atingiu o solo sob a cultura com valores de CUC de até 4,10 e $20 \%$, com a lavoura adulta. 


\section{REFERÊNCIAS BIBLIOGRÁFICAS}

AMERICAN SOCIETY OF AGRICULTURAL ENGINEERS. Procedure for sprinkler distribuition testing for research purposes. St. Joseph, 1984. P.457-9 (Asae Standards, ASAE S330).

AYARS, J.E.; HUTMACHER, R.B.; SCHONEMAN, R.A.; DETTINGER, D.R. Influence of cotton canopy on sprinkler irrigation uniformity. Transactions of the ASAE, v.34, n.3, p.890-6, 1991.

BRANSCHEID, V.O. \& HART, W.E. Predicting fiel distributions of sprinkler systems. Transactions of the ASAE, v.11, n.6, p.801-3,808, 1968.

CHAUDHRY, F.H. O papel da uniformidade de precipitação na produção. São Carlos, 1975. 80p. Tese (Livre Docência) - Escola de Engenharia de São Carlos, Universidade de São Paulo.

COGELS, O.G. An irrigation system uniformity function relating the effective uniformity of water application to the scale of influence of the plant root zones. Irrigation Science, v.4, n.4, p.289-99, 1983.

CONTE, M.L. ; LEOPOLDO, P.R. Estimativa da retenção de água de chuva pela cultura do milho. Engenharia Agrícola, v.10, n.1, p.47-54, 1986. 
COSTA, M.H.; SEDYIAMA, G.C.; COELHO, D.T. Coeficientes de cultura para o milho (Zea mays $L$ ) em 36 épocas de plantio. Engenharia na Agricultura, Série Irrigação e Drenagem, v.1, n.1, p. 1-9, 1992.

CHRISTIANSEN, J.E. Irrigation by sprinkling. California Agric. Expt. Station Bull, n.570, 1942.

DASTANE, N.G. Effective Rainfall in Irrigated Agriculture. Rome: FAO, 1974. 62p. (FAO. Irrigation and Drainage Paper, 25)

DOORENBOS, J. \& KASSAM, A.H. Efeito da água no rendimento das culturas. Campina Grande: UFPB, 1994. 306p.

EMPRESA BRASILEIRA DE PESQUISA AGROPECUÁRIA. Centro Nacional de Pesquisa de Milho e Sorgo Cultura do milho. Brasília: EMBRATER, 1983. 302p. ENDRES, V.C. ; MUNDSTOCK, C.M. Evolução da área foliar e duração do período de formação dos grãos de três híbridos de milho em duas épocas de semeadura. Pesquisa Agropecuária Brasileira, v.24, n.4, p.455-59, 1989.

FRANCIS, C.A.; RUTGER, J.N.; PALMER, F.E. A rapid method for plant leaf area estimation in maize (Zea mays L.). Crop Science, v.9, n.6, p.537-9, 1969.

FRIZZONE, J.A. Irrigação por aspersão - uniformidade e eficiência. Piracicaba: ESALQ, Departamento de Engenharia Rural, 1992. 53p. (Série Didática, 3).

HERMANN, D.F.; WALLENDER, W.W.; BOS, M.G. Irrigation eficiency and uniformity. In:HOFFMAN, G.J.; HOWELL, T.A.; SOLOMON, K.H. Management of farm irrigation systems. St. Joseph: ASAE, 1992. cap 2, p.?-? 
KELLER, J. ; BLIESNER, R.D. Sprinkle and trickle irrigation. New York: Van Nostrand Reinhold, 1990. 652p.

KELSO, G.L. ; GILLEY, J.R. A system for measuring infiltration rates under centerpivot irrigation systems. Transactions of the ASAE, v.29, n.4, p.1058-64, 1986.

KOHL, R.A. Sprinkler irrigation gage errors. Transactions of the ASAE, v.15, n.2, p.264-5,271, 1972.

LEOPOLDO, P.R.; SOUSA, A.P.; TUACEK FILHO, S. Intercepção da água de chuva em cultura de cana de açúcar. Brasil Açucareiro, v.98, n.6, p.9-16, 1981.

LETEY, J.; VAUX, H.J.; FEINERMAN, E. Optimun crop water application as affected by uniformity of water infiltration. Agronomy Journal, v.76, n.3, p.435-41, 1984.

LIMA, A.F. de ; SCALOPPI, E.J. Alternância de posição de aspersores em sistemas portáteis de irrigação por aspersão. In: CONGRESSO BRASILEIRO DE ENGENHARIA AGRÍCOLA, 24., Viçosa, 1995. Resumos. Viçosa: SBEA, 1995. p. 251.

LIVINGSTON, P.; LOFTIS, J.C.; DUKE, H.R. A wind tunnel study of sprinkler catchcan performance. Transactions of the ASAE, v.28, n.6, p.1962-5, 1985.

MERRIAM, J.L.; SHEARER, M.V.; BURT, C.M. evaluating irrigation systems and pratices. In: JENSEN, M.E. Design and operation of farm irrigation systems. St. Joseph: ASAE, 1983. p.583-618.

MIRANDA, R.A. ; BUTLER, D.R. interception of rainfall in a hedgerow apple orchard. Journal of Hidrology, v.87, n.2, p.245-53, 1986. 
PAIVA, J.B.D. Uniformidade de aplicação de água abaixo da superfície do solo utilizando irrigação por aspersão. São Carlos,1980. 330p. Dissertação (Mestrado) Escola de Engenharia de São Carlos, Universidade de São Paulo)

PESSOA, P.C.S. Desempenho de um sistema pivô central equipado com diferentes configurações de emissores ao longo do ciclo de uma cultura de milho. Piracicaba, 1994. 75p. Dissertação (Mestrado) - Escola Superior de Agricultura "Luiz de Queiróz", Universidade de São Paulo.

RAO, A.S. Interception losses of rainfall from cashew trees. Journal of Hidrology, v.90, n.2, p.293-301, 1987.

REZENDE, R. Desempenho de um sistema de irrigação pivô central quanto à uniformidade e eficiência de aplicação de água abaixo e acima da superfície do solo. Piracicaba, 1992 86p. Dissertação (Mestrado) - Escola Superior de Agricultura "Luiz de Queiróz", Universidade de São Paulo.

SAFFIGNA, P.G.; TENNER, C.B.; KEENEY, D.R. Non-umiform infiltration under potato canopies caused by interception, stemflow, and hilling. Agronomy Journal v.68, n.2, p.337-42, Mar./Apr. 1976.

SILVA, C.L. Modelagem da precipitação efetiva na cultura do milho. Viçosa, 1993. 82p. Tese (Doutorado) - Universidade Federal de Viçosa.

SOARES, A.A. Curso de engenharia da irrigação: métodos de irrigação - irrigação localizada e por aspersão. Brasília: ABEAS, 1992. 101p. 
SOLOMON, K.H. Yeld related interpretations of uniformity measures. Irrigation Science v.5, n.3, p.161-72, 1984.

STEINER, J.L.; KANEMASU, E.T.; CLARK, R.N. spray losses and partitioning of water under a center pivot sprinkler system. Transactions of the ASAE, v.26, n.4, p.1128-34, 1983.

VIEIRA, R.F. Introdução à quimigação. In: COSTA, E.F.; VIEIRA, R.F.; VIANA, P.A. ,ed. Quimigação: aplicação de produtos químicos e biológicos via irrigação. Brasilia: EMBRAPA,SPI, 1994. cp.1, p.13-40.

VON BERNUTH, R.D. Uniformity design criteria under limited water. Transactions of the ASAE, v.26, n.5, p.1418-21, 1983.

WILCOX, J.C. ; SWAILES, G.E. Uniformity of water distribution by some undertree orchard sprinkler. Scientific Agriculture, v.27, n.11, p.563-83, Nov. 1947.

WISLER, C.O. ; BRATER, E.F. Hidrologia. Rio de Janeiro: Ao Livro Técnico, 1964, $484 \mathrm{p}$.

ZASLAVSKY, D. ; BURAS, N. Crop yeld response to nonuniform aplication of irrigation water. Transactions of the ASAE, v.10, n.2, p.196-8,200, 1967.

ZOCOLER, J.L. Custos da irrigação por aspersão convencional em função da pressão de operação, diâmetros dos bocais e espaçamentos dos aspersores. Piracicaba, 1994. 120p. Dissertação (Mestrado) - Escola Superior de Agricultura "Luiz de Queiróz", Universidade de São Paulo. 
APÊNDICE 1 - Escoamento pelo colmo

- método para escolha das colunas de coletores onde seriam instalados os coletores do escoamento pelo colmo.

- volume de escoamento pelo colmo coletado nos diversos testes 
Seguem abaixo os cálculos para escolha da coluna de plantas onde seriam instalados os coletores do escoamento pelo colmo. Os quadros 01,02 e 03 apresentam os resultados dos três testes sem influência da cultura em termos de percentual em relação à média. A última linha, em itálico e negrito, apresentada a média de cada coluna. $\mathrm{O}$ quadro 04 reúne as últimas linhas dos quadros anteriores e fornece a média coletada por coluna nos três testes, possibilitando a escolha da coluna desejada. Optou-se pela de menor amplitude de variação. No caso da parcela $6 \times 12$, portanto, a coluna onde serão instalados os coletores de escoamento pelo colmo é a terceira. $\mathrm{Na} 12 \times 18$ a segunda e, na $18 \times 18$, a quarta coluna.

\begin{tabular}{|c|c|c|c|c|c|c|c|c|c|}
\hline \multicolumn{5}{|c|}{$\begin{array}{l}\text { PARCELA 6 X } 12 \\
\text { Quadro 01: }\end{array}$} & \multicolumn{5}{|c|}{ Quadro 02: } \\
\hline 107 & 97 & 86 & 88 & 101 & 75 & 66 & 93 & 150 & 127 \\
\hline 123 & 118 & 109 & 117 & 136 & 75 & 75 & 96 & 147 & 123 \\
\hline 126 & 101 & 107 & 109 & 126 & 104 & 96 & 104 & 104 & 104 \\
\hline 107 & 56 & 95 & 92 & 95 & 100 & 129 & 98 & 98 & 84 \\
\hline 100 & 90 & 92 & 91 & 83 & 88 & 95 & 102 & 103 & 93 \\
\hline 99 & 94 & 84 & 78 & 78 & 95 & 93 & 89 & 89 & 90 \\
\hline 90 & 90 & 92 & 88 & 92 & 86 & 85 & 91 & 94 & 94 \\
\hline 99 & 94 & 94 & 97 & 95 & 93 & 85 & 90 & 98 & 98 \\
\hline 100 & 105 & 95 & 108 & 112 & 104 & 109 & 96 & 105 & 109 \\
\hline 113 & 123 & 100 & 108 & 118 & 108 & 114 & 108 & 129 & 118 \\
\hline 106 & 97 & 95 & 98 & 104 & 93 & 95 & 97 & 112 & 104 \\
\hline \multicolumn{10}{|c|}{ Quadro 03: } \\
\hline 104 & 99 & 114 & 114 & 104 & & & & & \\
\hline 105 & 114 & 109 & 112 & 115 & & & & & \\
\hline 100 & 88 & 95 & 104 & 104 & & & & & \\
\hline 85 & 92 & 94 & 91 & 96 & & & & & \\
\hline 96 & 82 & 95 & 96 & 94 & & & & & \\
\hline 94 & 95 & 91 & 94 & 95 & & & & & \\
\hline 97 & 92 & 99 & 107 & 101 & \multicolumn{5}{|c|}{ Quadro 04: } \\
\hline 99 & 100 & 105 & 120 & 121 & 106 & 97 & 95 & 98 & 104 \\
\hline 105 & 92 & 97 & 123 & 131 & 93 & 95 & 97 & 112 & 104 \\
\hline 87 & 78 & 83 & 101 & 95 & 97 & 93 & 98 & 106 & 106 \\
\hline 97 & 93 & 98 & 106 & 106 & 100 & 96 & 96 & 105 & 104 \\
\hline \multicolumn{10}{|c|}{$\begin{array}{l}\text { PARCELA } 12 \times 18 \\
\text { Quadro 01: }\end{array}$} \\
\hline 130 & 85 & 71 & 88 & 207 & 130 & 90 & 72 & 81 & 179 \\
\hline 62 & 74 & 71 & 68 & 77 & 49 & 84 & 75 & 75 & 87 \\
\hline 48 & 82 & 85 & 77 & 71 & 38 & 81 & 90 & 90 & 78 \\
\hline 94 & 94 & 128 & 122 & 122 & 98 & 101 & 156 & 142 & 121 \\
\hline 102 & 119 & 145 & 142 & 116 & 92 & 130 & 150 & 156 & 110 \\
\hline 102 & 133 & 136 & 99 & 77 & 95 & 118 & 127 & 95 & 84 \\
\hline 91 & 82 & 88 & 77 & 71 & 72 & 84 & 84 & 72 & 66 \\
\hline 156 & 94 & 79 & 85 & 150 & 173 & 98 & 81 & 78 & 118 \\
\hline 98 & 95 & 100 & 95 & 111 & 94 & 98 & 104 & 99 & 105 \\
\hline \multicolumn{10}{|c|}{ Quadro 03: } \\
\hline 95 & 58 & 116 & 58 & 269 & & & & & \\
\hline 72 & 66 & 69 & 81 & 87 & & & & & \\
\hline 81 & 87 & 92 & 84 & 58 & & & & & \\
\hline 124 & 84 & 81 & 78 & 90 & & & & & \\
\hline 139 & 185 & 145 & 98 & 107 & \multicolumn{5}{|c|}{ Quadro 04: } \\
\hline 121 & 136 & 133 & 84 & 61 & 98 & 95 & 100 & 95 & 111 \\
\hline 95 & 87 & 92 & 81 & 58 & 94 & 98 & 104 & 99 & 105 \\
\hline 116 & 66 & 64 & 98 & 205 & 105 & 96 & 99 & 83 & 117 \\
\hline 105 & 96 & 99 & 83 & 117 & 99 & 97 & 101 & 92 & 111 \\
\hline
\end{tabular}




\begin{tabular}{|c|c|c|c|c|c|c|c|}
\hline \multicolumn{8}{|c|}{$\begin{array}{l}\text { PARCELA 18 X18 } \\
\text { Quadro 01: }\end{array}$} \\
\hline $\begin{array}{l}351 \\
130\end{array}$ & $\begin{array}{l}75 \\
36\end{array}$ & $\begin{array}{l}39 \\
39\end{array}$ & $\begin{array}{c}107 \\
99\end{array}$ & $\begin{array}{l}107 \\
110\end{array}$ & $\begin{array}{l}75 \\
67\end{array}$ & $\begin{array}{l}79 \\
39\end{array}$ & $\begin{array}{l}296 \\
142\end{array}$ \\
\hline 59 & 39 & 43 & 91 & 122 & 59 & 51 & 63 \\
\hline 99 & 91 & 75 & 91 & 95 & 107 & 107 & 122 \\
\hline 138 & 126 & 138 & 99 & 83 & 154 & 138 & 122 \\
\hline 107 & 103 & 99 & 91 & 110 & 83 & 99 & 107 \\
\hline 55 & 43 & 63 & 118 & 134 & 83 & 51 & 63 \\
\hline 158 & 55 & 71 & 126 & 138 & 91 & 59 & 189 \\
\hline 137 & 71 & 71 & 103 & 112 & 90 & 78 & 138 \\
\hline \multicolumn{8}{|c|}{ Quadro 02} \\
\hline 213 & $\begin{array}{l}60 \\
48\end{array}$ & 84 & $\begin{array}{l}100 \\
84\end{array}$ & 108 & $\begin{array}{l}48 \\
36\end{array}$ & 293 & $\begin{array}{r}241 \\
88\end{array}$ \\
\hline 48 & 52 & 96 & $\begin{array}{l}04 \\
80\end{array}$ & 88 & $\begin{array}{l}30 \\
44\end{array}$ & $\begin{array}{l}00 \\
52\end{array}$ & $\begin{array}{l}88 \\
52\end{array}$ \\
\hline 84 & 68 & 96 & 121 & 48 & 80 & 108 & 121 \\
\hline 201 & 145 & 64 & 24 & 121 & 169 & 157 & 165 \\
\hline 96 & 100 & 108 & 121 & 80 & 72 & 80 & 80 \\
\hline 68 & 72 & 129 & 169 & 76 & 52 & 56 & 72 \\
\hline 121 & 48 & 145 & 141 & 108 & 36 & 121 & 217 \\
\hline 113 & 74 & 102 & 105 & 91 & 67 & 117 & 130 \\
\hline \multicolumn{8}{|c|}{ Quadro 03: } \\
\hline 226 & 66 & 89 & 155 & 80 & 58 & 102 & 155 \\
\hline 44 & 58 & 84 & 102 & 71 & 75 & 62 & 66 \\
\hline 71 & 66 & 71 & 35 & 49 & 120 & 142 & 106 \\
\hline 155 & 124 & 58 & 4 & 58 & 120 & 146 & 137 \\
\hline 120 & 124 & 97 & 49 & 66 & 71 & 71 & 102 \\
\hline 58 & 71 & 133 & 133 & 62 & 53 & 49 & 53 \\
\hline 115 & 80 & 120 & 186 & 75 & 49 & 115 & 275 \\
\hline 142 & 80 & 124 & 199 & 80 & 62 & 142 & 292 \\
\hline 116 & 84 & 97 & 108 & 68 & 76 & 104 & 148 \\
\hline \multicolumn{8}{|c|}{ Quadro 04: } \\
\hline 137 & 71 & 71 & 103 & 112 & 90 & 78 & 138 \\
\hline 113 & 74 & 102 & 105 & 91 & 67 & 117 & 130 \\
\hline 116 & 84 & 97 & 108 & 68 & 76 & 104 & 148 \\
\hline 121 & 78 & 92 & 106 & 85 & 77 & 100 & 141 \\
\hline
\end{tabular}


O quadro abaixo apresenta o volume escoado pelo colmo em relação ao volume total aplicado por planta.

Na Parcela I são aplicados em média 908,3 $1 / \mathrm{h}(2,8 \mathrm{~mm} / \mathrm{h})$ sobre 6 plantas $/ \mathrm{m}^{2}$; consequentemente, 0,47 1/planta.hora. A coluna escolhida para coleta do Ec recebe $105,17 \%$ da média precipitada em cada coluna, portanto o volume total aplicado por planta na coluna 04 é de 0,49 1/planta.hora.

$\mathrm{Na}$ Parcela II são aplicados em média $868,3 \mathrm{l} / \mathrm{h}(4,2 \mathrm{~mm} / \mathrm{h})$ sobre 5,8 plantas $/ \mathrm{m}^{2}$; consequentemente, 0,69 1/planta.hora. A coluna escolhida para coleta do Ec recebe 96,56\% da média precipitada em cada coluna, portanto o volume total aplicado por planta na coluna 02 é de 0,67 1/planta.hora.

Na Parcela III são aplicados em média $650,91 / \mathrm{h}(9,04 \mathrm{~mm} / \mathrm{h})$ sobre 6,2 plantas $/ \mathrm{m}^{2}$; consequentemente, 1,46 1/planta.hora. A coluna escolhida para coleta do Ec recebe $96,73 \%$ da média precipitada em cada coluna, portanto o volume total aplicado por planta na coluna 03 é de 1,41 l/planta.hora.

\begin{tabular}{ccccccccccc}
\hline & \multicolumn{4}{c}{ Parcela I } & \multicolumn{4}{c}{ Parcela II } & \multicolumn{3}{c}{ Parcela III } \\
\hline Data & Pt & Ec & Ec/Pt & Pt & Ec & Ec/Pt & Pt & Ec & Ec/Pt \\
\hline $17 / 07$ & 0,49 & 0,13 & 0,265 & 0,67 & 0,27 & 0,403 & & & \\
$21 / 07$ & 0,49 & 0,17 & 0,337 & 0,67 & 0,15 & 0,224 & 1,41 & 0,46 & 0,329 \\
$26 / 07$ & 0,49 & 0,14 & 0,276 & 0,67 & 0,26 & 0,388 & 1,41 & 0,49 & 0,350 \\
$01 / 08$ & 0,49 & 0,18 & 0,376 & 0,67 & 0,25 & 0,373 & 1,41 & 0,51 & 0,364 \\
$03 / 08$ & 0,49 & 0,16 & 0,331 & 0,67 & 0,22 & 0,328 & 1,41 & 0,64 & 0,457 \\
$07 / 08$ & 0,49 & 0,15 & 0,304 & 0,67 & 0,22 & 0,328 & 1,41 & 0,55 & 0,393 \\
$09 / 08$ & 0,49 & 0,16 & 0,325 & 0,67 & 0,27 & 0,403 & 1,41 & 0,55 & 0,393 \\
$14 / 08$ & 0,49 & 0,14 & 0,284 & 0,67 & 0,26 & 0,388 & 1,41 & 0,56 & 0,400 \\
$21 / 08$ & 0,49 & 0,13 & 0,265 & 0,67 & 0,21 & 0,313 & 1,41 & 0,57 & 0,407 \\
$23 / 08$ & 0,49 & 0,18 & 0,367 & 0,67 & 0,21 & 0,313 & 1,41 & 0,45 & 0,321 \\
$28 / 08$ & 0,49 & 0,18 & 0,367 & 0,67 & 0,19 & 0,284 & 1,41 & 0,45 & 0,321 \\
$30 / 08$ & 0,49 & 0,14 & 0,286 & 0,67 & 0,18 & 0,269 & 1,41 & 0,43 & 0,307 \\
$13 / 09$ & 0,49 & 0,09 & 0,184 & 0,67 & 0,20 & 0,299 & 1,41 & 0,28 & 0,196 \\
\hline
\end{tabular}


APÊNDICE 2 - Condições climáticas do periodo de experimento e cálculo da soma térmica 


\begin{tabular}{|c|c|c|c|c|c|c|c|c|}
\hline & \multicolumn{4}{|c|}{ Temperatura } & \multirow[b]{2}{*}{ Evaporacao } & \multirow{2}{*}{\multicolumn{2}{|c|}{ Soma térmica }} & \multirow[b]{3}{*}{ Dias } \\
\hline & precipitação & máxima & mínima & media & & & & \\
\hline Data & $\mathrm{mm}$ & & centígrados & & $\mathrm{mm}$ & Diária & Acumulada & \\
\hline $1 / a b r / 95$ & 15,60 & 27,50 & 19,20 & 23,35 & 6,52 & & & \\
\hline $2 / a b r / 95$ & 0,00 & 28.00 & 19,00 & 23,50 & 6,46 & & & \\
\hline $3 / \mathrm{abr} / 95$ & 0,00 & 28.40 & 12,90 & 20,65 & 5,46 & & & \\
\hline $4 / a b r / 95$ & 0,00 & 29,40 & 16,10 & 22,75 & 4,91 & & & \\
\hline $5 / a b r / 95$ & 0,00 & 30,60 & 16,10 & 23,35 & 4,78 & & & \\
\hline 6/abr/95 & 0,00 & 30,40 & 16,90 & 23,65 & 2,87 & & & \\
\hline $7 / \mathrm{abr} / 95$ & 0,00 & 31,50 & 19,20 & 25,35 & 5,67 & & & \\
\hline $8 / a b r / 95$ & 0,00 & 30,90 & 17,40 & 24,15 & 3,40 & & & \\
\hline 9/abr/95 & 8,00 & 31.20 & 18,60 & 24,90 & 4,30 & & & \\
\hline $10 / a b r / 95$ & 0,20 & 31,40 & 18,30 & 24,85 & 4,44 & 14,15 & 14,15 & 1 \\
\hline $11 / \mathrm{abr} / 95$ & 7,70 & 31,20 & 19,00 & 25,10 & 5,56 & 14,50 & 28,65 & 2 \\
\hline $12 / \mathrm{abr} / 95$ & 0,00 & 25,80 & 18,80 & 22,30 & 5,36 & 12,30 & 40,95 & 3 \\
\hline $13 / a b r / 95$ & 0,00 & 26.00 & 10,40 & 18,20 & 5,08 & 8,20 & 49,15 & 4 \\
\hline 14/abr/95 & 0,00 & 27,20 & 13,40 & 20,30 & 5,30 & 10,30 & 59,45 & 5 \\
\hline $15 / \mathrm{abr} / 95$ & 0,00 & 28.80 & 11,80 & 20,30 & 3,32 & 10,30 & 69,75 & 6 \\
\hline $16 / a b r / 95$ & 0,00 & 29.20 & 12,80 & 21,00 & 4.60 & 11,00 & 80,75 & 7 \\
\hline $17 / a b r / 95$ & 0,00 & 29,80 & 14,00 & 21,90 & 4,30 & 11,90 & 92,65 & 8 \\
\hline 18/abr/95 & 0,00 & 30,00 & 15,80 & 22,90 & 3,80 & 12,90 & 105,55 & 9 \\
\hline $19 / \mathrm{abr} / 95$ & 7,40 & 32.50 & 18,80 & 25,65 & 3,83 & 14,40 & 119,95 & 10 \\
\hline 20/abr/95 & 46,80 & 27.80 & 20,00 & 23,90 & 5,83 & 13,90 & 133,85 & 11 \\
\hline $21 / a b r / 95$ & 0,00 & 26,20 & 18,00 & 22,10 & 2,92 & 12,10 & 145,95 & 12 \\
\hline 22/abr/9s & 0,00 & 27,00 & 14,80 & 20,90 & 2,66 & 10,90 & 156,85 & 13 \\
\hline 23/abr/95 & 0,00 & 28,00 & 15,00 & 21,50 & 4,48 & 11,50 & 168,35 & 14 \\
\hline 24/abr/95 & 0,00 & 28,50 & 13,20 & 20,85 & 4,04 & 10,85 & 179,20 & 15 \\
\hline $25 / a b r / 95$ & 0,00 & 29.80 & 13,70 & 21,75 & 4,44 & 11,75 & 190,95 & 16 \\
\hline 26/abr/95 & 0,00 & 30.10 & 13,50 & 21,80 & 3,36 & 11,75 & 202,70 & 17 \\
\hline $27 / \mathrm{abr} / 95$ & 0,00 & 28.10 & 16,40 & 22,25 & 2,76 & 12,25 & 214,95 & 18 \\
\hline $28 / \mathrm{abr} / 95$ & 0,00 & 29.70 & 15,20 & 22,45 & 8,02 & 12,45 & 227,40 & 19 \\
\hline 29/abr/95 & 0,00 & 30.00 & 15,50 & 22,75 & 4,20 & 12,75 & 240,15 & 20 \\
\hline $30 / a b r / 95$ & 0,00 & 31.40 & 15,10 & 23,25 & 3,00 & 12,55 & 252,70 & 21 \\
\hline $1 / \mathrm{mai} / 95$ & 0,00 & 32.00 & 15,50 & 23,75 & 4,00 & 12,75 & 265,45 & 22 \\
\hline $2 / \mathrm{mai} / 95$ & 0,00 & 30.10 & 15,50 & 22,80 & 4,45 & 12,75 & 278,20 & 23 \\
\hline $3 / \mathrm{mai} / 95$ & 0,00 & 28.00 & 16,10 & 22,05 & 4,09 & 12,05 & 290,25 & 24 \\
\hline 4/mai/95 & 0,00 & 29.60 & 13,30 & 21,45 & 1,94 & 11,45 & 301,70 & 25 \\
\hline $5 / \mathrm{mai} / 95$ & 0,40 & 29.50 & 14,20 & 21,85 & 3,06 & 11,85 & 313,55 & 26 \\
\hline $6 / \mathrm{mai} / 95$ & 7,50 & 23.30 & 19,20 & 21,25 & 0,26 & 11,25 & 324,80 & 27 \\
\hline $7 / \mathrm{mai} / 95$ & 0,50 & 24.00 & 19,90 & 21,95 & 1,14 & 11,95 & 336,75 & 28 \\
\hline $8 / \mathrm{mai} / 95$ & 0,00 & 26.70 & 16,40 & 21,55 & 2,58 & 11,55 & 348,30 & 29 \\
\hline 9/mai/95 & 5,30 & 27.70 & 15,80 & 21,75 & 3,54 & 11,75 & 360,05 & 30 \\
\hline $10 / \mathrm{mai} / 95$ & 15,20 & 18.70 & 17,50 & 18,10 & 0,68 & 8,10 & 368,15 & 31 \\
\hline $11 / \mathrm{mai} / 95$ & 0,00 & 23.30 & 12,50 & 17,90 & 0,62 & 7,90 & 376,05 & 32 \\
\hline $12 / \mathrm{mai} / 95$ & 0,00 & 26.90 & 12,80 & 19,85 & 3,22 & 9,85 & 385,90 & 33 \\
\hline $13 / \mathrm{mai} / 95$ & 0,00 & 29.00 & 13,10 & 21,05 & 3,34 & 11,05 & 396,95 & 34 \\
\hline $14 / \mathrm{mai} / 95$ & 0,00 & 29.40 & 13,70 & 21,55 & 3,02 & 11,55 & 408,50 & 35 \\
\hline $15 / \mathrm{mai} / 95$ & 0,00 & 29.50 & 14,60 & 22,05 & 3,11 & 12,05 & 420,55 & 36 \\
\hline $16 / \mathrm{mai} / 95$ & 30,60 & 29.30 & 15,60 & 22,45 & 4,97 & 12,45 & 433,00 & 37 \\
\hline 17/mai/95 & 0,00 & 29.30 & 16,90 & 23,10 & 3,19 & 13,10 & 446,10 & 38 \\
\hline $18 / \mathrm{mai} / 95$ & 4,50 & 22.70 & 16,70 & 19,70 & 2,12 & 9,70 & 455,80 & 39 \\
\hline $19 / \mathrm{mai} / 95$ & 0,00 & 22.00 & 11,90 & 16,95 & 4,63 & 6,95 & 462,75 & 40 \\
\hline 20/mai/95 & 0,20 & 22.20 & 8,10 & 15,15 & 2,56 & 6,10 & 468,85 & 41 \\
\hline $21 / \mathrm{mai} / 95$ & 0,00 & 22.30 & 10,00 & 16,15 & 1,26 & 6,15 & 475,00 & 42 \\
\hline $22 / \mathrm{mai} / 95$ & 0,00 & 23.80 & 8,90 & 16,35 & 2,31 & 6,90 & 481,90 & 43 \\
\hline $23 / \mathrm{mai} / 95$ & 0,00 & 25,10 & 10,00 & 17,55 & 2,35 & 7,55 & 489,45 & 44 \\
\hline 24/mai/95 & 0,00 & 25.70 & 12,00 & 18,85 & 2,08 & 8,85 & 498,30 & 45 \\
\hline $25 / \mathrm{mai} / 95$ & 0,00 & 25.20 & 13,40 & 19,30 & 2,46 & 9,30 & 507,60 & 46 \\
\hline $26 / \mathrm{mai} / 95$ & 0,00 & 22.40 & 13,40 & 17,90 & 4,26 & 7,90 & 515,50 & 47 \\
\hline $27 / \mathrm{mai} / 95$ & 0,00 & 26.20 & 12,70 & 19,45 & 2,66 & 9,45 & 524,95 & 48 \\
\hline $28 / \mathrm{mai} / 95$ & 0,00 & 27.40 & 11,80 & 19,60 & 2,26 & 9,60 & 534,55 & 49 \\
\hline 29/mai/95 & 0,00 & 25.00 & 12,50 & 18,75 & 1,76 & 8,75 & 543,30 & 50 \\
\hline $30 / \mathrm{mai} / 95$ & 0,00 & 24.00 & 12,10 & 18,05 & 3,12 & 8,05 & 551,35 & 51 \\
\hline $31 / \mathrm{mai} / 95$ & 0,00 & 23.70 & 8,70 & 16,20 & 2,85 & 6,85 & 558,20 & 52 \\
\hline
\end{tabular}




\begin{tabular}{|c|c|c|c|c|c|c|c|c|}
\hline \multirow[b]{3}{*}{ Data } & \multirow{3}{*}{$\frac{\text { precipitação }}{\mathrm{mm}}$} & \multicolumn{3}{|c|}{ Temperatura } & \multirow[b]{2}{*}{ Evaporacao } & \multirow{2}{*}{\multicolumn{2}{|c|}{ Soma térmica }} & \multirow[b]{3}{*}{ Dias } \\
\hline & & máxima & minima & media & & & & \\
\hline & & \multicolumn{3}{|c|}{ graus centígrados } & $\mathrm{mm}$ & Diária & Acumulada & \\
\hline I/jun/95 & 0,00 & 26,00 & 9,00 & 17,50 & 2,94 & 8,00 & 566,20 & 53 \\
\hline 2/jun/95 & 0,00 & 26,80 & 10,30 & 18,55 & 3,57 & 8,55 & 574,75 & 54 \\
\hline $3 / \mathrm{jun} / 95$ & 0,00 & 25,20 & 11,40 & 18,30 & 2,98 & 8,30 & 583,05 & 55 \\
\hline $4 /$ jun/ 95 & 0,00 & 25,40 & 9,60 & 17,50 & 3,60 & 7,70 & 590,75 & 56 \\
\hline $5 / \mathrm{jun} / 95$ & 0,00 & 26,20 & 6,40 & 16,30 & 1,36 & 8,10 & 598,85 & 57 \\
\hline 6/jun/95 & 0,00 & 27,00 & 8,90 & 17,95 & 3,26 & 8,50 & 607,35 & 58 \\
\hline $7 /$ jun/95 & 0,00 & 28,00 & 10,80 & 19,40 & 3,50 & 9,40 & 616,75 & 59 \\
\hline $8 /$ jun/95 & 0,00 & 27,60 & 9,90 & 18,75 & 1,80 & 8,80 & 625,55 & 60 \\
\hline 9/jun/95 & 0,00 & 28,20 & 11,20 & 19,70 & 5,06 & 9,70 & 635,25 & 61 \\
\hline $10 / j u n / 95$ & 0,00 & 27,60 & 9,20 & 18,40 & 3,97 & 8,80 & 644,05 & 62 \\
\hline $1 \mathrm{l} / \mathrm{jun} / 95$ & 0,00 & 28,40 & 10,60 & 19,50 & 3,27 & 9,50 & 653,55 & 63 \\
\hline $12 /$ jun/95 & 0,00 & 27,60 & 10,60 & 19,10 & 2,64 & 9,10 & 662,65 & 64 \\
\hline 13/jun/95 & 0,00 & 27,60 & 9,60 & 18,60 & 2,44 & 8,80 & 671,45 & 65 \\
\hline 14/jun/95 & 0,00 & 27,50 & 10,60 & 19,05 & 3,22 & 9,05 & 680,50 & 66 \\
\hline $15 / \mathrm{jun} / 95$ & 0,00 & 28,10 & 10,10 & 19,10 & 3,00 & 9,10 & 689,60 & 67 \\
\hline 16/jun/95 & 0,00 & 28,50 & 14,70 & 21,60 & 3,82 & 11,60 & 701,20 & 68 \\
\hline $17 /$ jun/95 & 2,70 & 24,60 & 12,90 & 18,75 & 0,49 & 8,75 & 709,95 & 69 \\
\hline 18/jun/95 & 10,20 & 21,60 & 16,00 & 18,80 & 0,99 & 8,80 & 718,75 & 70 \\
\hline 19/jun/95 & 0,00 & 21,40 & 13,20 & 17,30 & 2,40 & 7,30 & 726,05 & 71 \\
\hline 20/jun/95 & 0,00 & 22,60 & 10,40 & 16,50 & 3,00 & 6,50 & 732,55 & 72 \\
\hline 21/jun/95 & 0,00 & 22,80 & 9,00 & 15,90 & 1,64 & 6,40 & 738,95 & 73 \\
\hline $22 /$ jun/95 & 0,00 & 27,00 & 11,20 & 19,10 & 2,12 & 9,10 & 748,05 & 74 \\
\hline 23/jun/95 & 0,00 & 28,00 & 11,10 & 19,55 & 3,16 & 9,55 & 757,60 & 75 \\
\hline 24/jun/95 & 0,00 & 27,40 & 12,00 & 19,70 & 3,99 & 9,70 & 767,30 & 76 \\
\hline $25 /$ jun/95 & 10,60 & 18,80 & 17,30 & 18,05 & 2,17 & 8,05 & 775,35 & 77 \\
\hline 26/jun/95 & 0,00 & 24,80 & 14,00 & 19,40 & 1,82 & 9,40 & 784,75 & 78 \\
\hline $27 /$ jun/95 & 0,00 & 29,20 & 12,10 & 20,65 & 2,86 & 10,65 & 795,40 & 79 \\
\hline 28/jun/95 & 0,00 & 29,80 & 12,40 & 21,10 & 2,98 & 11,10 & 806,50 & 80 \\
\hline 29/jun/95 & 0,00 & 21,90 & 15,10 & 18,50 & 1,01 & 8,50 & 815,00 & 81 \\
\hline $30 /$ jun/95 & 0,00 & 23,10 & 11,40 & 17,25 & 3,97 & 7,25 & 822,25 & 82 \\
\hline 1/jul/95 & 0,00 & 26,80 & 10,40 & 18,60 & 3,06 & 8,60 & 830,85 & 83 \\
\hline $2 / \mathrm{jul} / 95$ & 0,00 & 28,50 & 11,00 & 19,75 & 2,86 & 9,75 & 840,60 & 84 \\
\hline $3 / \mathrm{jul} / 95$ & 0,00 & 28,40 & 13,00 & 20,70 & 3,40 & 10,70 & 851,30 & 85 \\
\hline $4 / \mathrm{jul} / 95$ & 0,00 & 26,30 & 13,30 & 19,80 & 3,54 & 9,80 & 861,10 & 86 \\
\hline $5 / \mathrm{jul} / 95$ & 0,00 & 28,30 & 11,50 & 19,90 & 3,33 & 9,90 & 871,00 & 87 \\
\hline 6/jul/95 & 0,00 & 29,00 & 15,60 & 22,30 & 3,61 & 12,30 & 883,30 & 88 \\
\hline 7/jul/95 & 0,50 & 29,50 & 15,90 & 22,70 & 4,30 & 12,70 & 896,00 & 89 \\
\hline $8 /$ jul/95 & 7,20 & 16,70 & 13,80 & 15,25 & 0,24 & 5,25 & 901,25 & 90 \\
\hline 9/jul/95 & 44,10 & 17,40 & 14,70 & 16,05 & 2.94 & 6,05 & 907,30 & 91 \\
\hline 10/jul/95 & 1,00 & 22,70 & 15,20 & 18,95 & 0,89 & 8,95 & 916,25 & 92 \\
\hline $11 / \mathrm{jul} / 95$ & 0,00 & 25,20 & 10,00 & 17,60 & 2,37 & 7,60 & 923,85 & 93 \\
\hline $12 / \mathrm{jul} / 95$ & 0,00 & 27,10 & 10,20 & 18,65 & 2,97 & 8,65 & 932,50 & 94 \\
\hline 13/jul/95 & 0,00 & 28,70 & 11,10 & 19,90 & 1,75 & 9,90 & 942,40 & 95 \\
\hline $14 / \mathrm{jul} / 95$ & 0,00 & 29,00 & 12,00 & 20,50 & 4,17 & 10,50 & 952,90 & 96 \\
\hline $15 / \mathrm{jul} / 95$ & 0,00 & 28,20 & 15,00 & 21,60 & 2,11 & 11,60 & 964,50 & 97 \\
\hline I6/jul/95 & 0,00 & 28,80 & 17,60 & 23,20 & 2,72 & 13,20 & 977,70 & 98 \\
\hline $17 / \mathrm{jul} / 95$ & 0,00 & 29,30 & 14,40 & 21,85 & 3,08 & 11,85 & 989,55 & 99 \\
\hline 18/jul/95 & 0,00 & 26,70 & 14,10 & 20,40 & 3,52 & 10,40 & 999,95 & 100 \\
\hline 19/jul/95 & 0,00 & 28,00 & 12,00 & 20,00 & 4,28 & 10,00 & 1009,95 & 101 \\
\hline $20 / \mathrm{jul} / 95$ & 0,40 & 20,40 & 17,90 & 19,15 & 1,78 & 9,15 & 1019,10 & 102 \\
\hline $2 \mathrm{l} / \mathrm{jul} / 95$ & 5,90 & 21,20 & 11,20 & 16,20 & 1,72 & 6,20 & 1025,30 & 103 \\
\hline $22 / \mathrm{jul} / 95$ & 0,00 & 20,20 & 11,00 & 15,60 & 1,28 & 5,60 & 1030,90 & 104 \\
\hline 23/jul/95 & 0,00 & 25,10 & 7,70 & 16,40 & 2,28 & 7,55 & 1038,45 & 105 \\
\hline 24/jul/95 & 0,00 & 29,30 & 9,70 & 19,50 & 3,32 & 9,65 & 1048,10 & 106 \\
\hline 25/jul/95 & 0,00 & 29,60 & 11,10 & 20,35 & 3,96 & 10,35 & 1058,45 & 107 \\
\hline 26/jul/95 & 0,00 & 29,40 & 12,60 & 21,00 & 3,72 & 11,00 & 1069,45 & 108 \\
\hline $27 /$ jul/95 & 0,00 & 29,50 & 12,00 & 20,75 & 3,39 & 10,75 & 1080,20 & 109 \\
\hline 28/jul/95 & 0,00 & 29,70 & 15,10 & 22,40 & 6,13 & 12,40 & 1092,60 & 110 \\
\hline 29/jul/95 & 0,00 & 31,00 & 14,80 & 22,90 & 4,60 & 12,40 & 1105,00 & 111 \\
\hline $30 /$ jul/95 & 0,00 & 30,00 & 12,90 & 21,45 & 2,40 & 11,45 & 1116,45 & 112 \\
\hline $31 / \mathrm{jul} / 95$ & 0,00 & 30,30 & 12,30 & 21,30 & 3,94 & 11,15 & 1127,60 & 113 \\
\hline
\end{tabular}




\begin{tabular}{|c|c|c|c|c|c|c|c|c|}
\hline \multirow[b]{3}{*}{ Data } & \multirow{3}{*}{$\begin{array}{c}\text { precipitação } \\
\mathrm{mm}\end{array}$} & \multicolumn{3}{|c|}{ Temperatura } & \multirow{3}{*}{$\frac{\text { Evaporacao }}{\mathrm{mm}}$} & \multirow{2}{*}{\multicolumn{2}{|c|}{ Soma térmica }} & \multirow[b]{3}{*}{ Dias } \\
\hline & & máxima & mínima & media & & & & \\
\hline & & \multicolumn{3}{|c|}{ graus centígrados } & & Diária & Acumulada & \\
\hline l/ago/95 & 0,00 & 29,20 & 12,40 & 20,80 & 5,10 & 10,80 & 1138,40 & 114 \\
\hline 2/ago/95 & 0,00 & 29,40 & 10,30 & 19,85 & 4,66 & 9,85 & 1148,25 & 115 \\
\hline $3 /$ ago/95 & 0,00 & 31,50 & 13,00 & 22,25 & 3,14 & 11,50 & 1159,75 & 116 \\
\hline 4/ago/95 & 0,90 & 23,40 & 14,90 & 19,15 & 5,08 & 9,15 & 1168,90 & 117 \\
\hline 5/ago/95 & 0,30 & 16,80 & 13,50 & 15,15 & 1,92 & 5,15 & 1174,05 & 118 \\
\hline 6/ago/95 & 0,00 & 23,80 & 12,00 & 17,90 & 2,76 & 7,90 & 1181,95 & 119 \\
\hline 7/ago/95 & 0.00 & 31,60 & 12,50 & 22,05 & 4,04 & 11,25 & 1193,20 & 120 \\
\hline 8/ago/95 & 0,00 & 32,00 & 16,30 & 24,15 & 4,16 & 13,15 & 1206,35 & 121 \\
\hline 9/ago/95 & 0,00 & 31,40 & 15,70 & 23,55 & 5,22 & 12,85 & 1219,20 & 122 \\
\hline 10/ago/95 & 0,00 & 31,90 & 14,60 & 23,25 & 4,49 & 12,30 & 1231,50 & 123 \\
\hline 11/ago/95 & 0,00 & 31,30 & 13,00 & 22,15 & 5,02 & 11,50 & 1243,00 & 124 \\
\hline 12/ago/95 & 0,00 & 32,30 & 13,20 & 22,75 & 5,14 & 11,60 & 1254,60 & 125 \\
\hline 13/ago/95 & 0,00 & 32,60 & 13,40 & 23,00 & 4,56 & 11,70 & 1266,30 & 126 \\
\hline 14/ago/95 & 0,00 & 33,30 & 11,90 & 22,60 & 5,98 & 10,95 & 1277,25 & 127 \\
\hline 15/ago/95 & 0,00 & 32,60 & 12,80 & 22,70 & 6,46 & 11,40 & 1288,65 & 128 \\
\hline 16/ago/95 & 0,00 & 32,00 & 13,60 & 22,80 & 3,41 & 11,80 & 1300,45 & 129 \\
\hline 17/ago/95 & 0,00 & 28,30 & 14,60 & 21,45 & 4,42 & 11,45 & 1311,90 & 130 \\
\hline 18/ago/95 & 0,00 & 30,60 & 12,40 & 21,50 & 5,46 & 11,20 & 1323,10 & 131 \\
\hline 19/ago/95 & 0,00 & 26,40 & 14,40 & 20,40 & 5,76 & 10,40 & 1333,50 & 132 \\
\hline 20/ago/95 & 0,00 & 27,40 & 12,60 & 20,00 & 4,48 & 10,00 & 1343,50 & 133 \\
\hline 21/ago/95 & 0,00 & 29,40 & 11,10 & 20,25 & 4,16 & 10,25 & 1353,75 & 134 \\
\hline 22/ago/95 & 0,00 & 30,40 & 12,60 & 21,50 & 3,80 & 11,30 & 1365,05 & 135 \\
\hline 23/ago/95 & 0,00 & 31,10 & 12,80 & 21,95 & 5,60 & 11,40 & 1376,45 & 136 \\
\hline 24/ago/95 & 0,00 & 31,50 & 13,20 & 22,35 & 5,88 & 11,60 & 1388,05 & 137 \\
\hline 25/ago/95 & 0,00 & 31,60 & 10,80 & 21,20 & 5,90 & 10,40 & 1398,45 & 138 \\
\hline 26/ago/95 & 0,00 & 31,50 & 10,80 & 21,15 & 5,54 & 10,40 & 1408,85 & 139 \\
\hline 27/ago/95 & 0.00 & 32,50 & 12,50 & 22,50 & 6,08 & 11,25 & 1420,10 & 140 \\
\hline 28/ago/95 & 0,00 & 32,60 & 13,00 & 22,80 & 3,61 & 11,50 & 1431,60 & 141 \\
\hline 29/ago/95 & 0,00 & 33,60 & 14,10 & 23,85 & 6,11 & 12,05 & 1443,65 & 142 \\
\hline 30/ago/95 & 0,00 & 34,50 & 12,80 & 23,65 & 6,90 & 11,40 & 1455,05 & 143 \\
\hline $31 / \mathrm{ago} / 95$ & 0,00 & 34,30 & 13,60 & 23,95 & 5,60 & 11,80 & 1466,85 & 144 \\
\hline I/set/95 & 0,00 & 34,80 & 13,00 & 23,90 & 7,76 & 11,50 & 1478,35 & 145 \\
\hline $2 /$ sev 95 & 0,00 & 33,70 & 14,20 & 23,95 & 6,58 & 12,10 & 1490,45 & 146 \\
\hline $3 /$ set $/ 95$ & 0,00 & 26,70 & 14,70 & 20,70 & 5,66 & 10,70 & 1501,15 & 147 \\
\hline $4 / \mathrm{set} / 95$ & 0,00 & 25,80 & 15,00 & 20,40 & 5,76 & 10,40 & 1511,55 & 148 \\
\hline $5 /$ set $/ 95$ & 0,00 & 26,90 & 8,90 & 17,90 & 6,12 & 8,45 & 1520,00 & 149 \\
\hline $6 / \mathrm{set} / 95$ & 0,00 & 29,20 & 8,20 & 18,70 & 6,06 & 9,60 & 1529,60 & 150 \\
\hline $7 / \mathrm{set} / 95$ & 0.00 & 30,20 & 9,40 & 19,80 & 5,78 & 10,00 & 1539,60 & 151 \\
\hline $8 / \mathrm{set} / 95$ & 0,00 & 32,20 & 9,90 & 21,05 & 5,98 & 10,00 & 1549,60 & 152 \\
\hline $9 / \mathrm{set} / 95$ & 0,00 & 33,60 & 10,40 & 22,00 & 6,28 & 10,20 & 1559,80 & 153 \\
\hline $10 /$ set $/ 95$ & 0,00 & 34,70 & 12,70 & 23,70 & 6,68 & 11,35 & 1571,15 & 154 \\
\hline $11 /$ set/95 & 0,00 & 35,50 & 13,90 & 24,70 & 7,26 & 11,95 & 1583.10 & 155 \\
\hline $12 / \mathrm{set} / 95$ & 0,00 & 27,60 & 16,30 & 21,95 & 6,07 & 11,95 & 1595,05 & 156 \\
\hline $13 /$ set/95 & 0,00 & 28,40 & 15,20 & 21,80 & 3,97 & 11,80 & 1606,85 & 157 \\
\hline $14 /$ set 95 & 0,00 & 34,60 & 14,60 & 24,60 & 5,86 & 12,30 & 1619,15 & 158 \\
\hline $15 / \mathrm{set} / 95$ & 0,00 & 30,20 & 19,40 & 24,80 & 6,31 & 14,70 & 1633,85 & 159 \\
\hline $16 / \mathrm{set} / 95$ & 0,00 & 28,50 & 10,80 & 19,65 & 7,12 & 9,65 & 1643,50 & 160 \\
\hline $17 /$ set 95 & 3,50 & 23,80 & 11,40 & 17,60 & 1,94 & 7,60 & 1651,10 & 161 \\
\hline $18 / \mathrm{set} / 95$ & 3,90 & 34,30 & 16,60 & 25,45 & 5,54 & 13,30 & 1664,40 & 162 \\
\hline $19 /$ set $/ 95$ & 5,50 & 30,50 & 18,70 & 24,60 & 6,56 & 14,35 & 1678,75 & 163 \\
\hline $20 /$ set $/ 95$ & 0,60 & 16,90 & 14,00 & 15,45 & 2,54 & 5,45 & 1684,20 & 164 \\
\hline $21 / \mathrm{set} / 95$ & 0,00 & 20,60 & 12,90 & 16,75 & 3,50 & 6,75 & 1690,95 & 165 \\
\hline $22 / \mathrm{set} / 95$ & 0,00 & 29,70 & 13,00 & 21,35 & 5,94 & & & \\
\hline $23 / \mathrm{set} / 95$ & 4,60 & 23,60 & 15,40 & 19,50 & 2,15 & & & \\
\hline $24 /$ set $/ 95$ & 8,90 & 24,80 & 17,30 & 21,05 & 1,61 & & & \\
\hline $25 / \mathrm{set} / 95$ & 0,00 & 27,80 & 16,80 & 22,30 & 4,06 & & & \\
\hline $26 /$ set $/ 95$ & 10,00 & 32,30 & 15,20 & 23,75 & 5,20 & & & \\
\hline $27 / \mathrm{set} / 95$ & 0,30 & 25,60 & 16,00 & 20,80 & 2,86 & & & \\
\hline $28 /$ set $/ 95$ & 0,30 & 24,60 & 16,40 & 20,50 & 1,84 & & & \\
\hline $29 / \mathrm{set} / 95$ & 0,00 & 26,60 & 15,20 & 20,90 & 3,58 & & & \\
\hline $30 /$ set $/ 95$ & 0,00 & 31,70 & 16,10 & 23,90 & 6,28 & & & \\
\hline
\end{tabular}


APÊNDICE 3 - Índice de área foliar e altura das plantas 


\begin{tabular}{|c|c|c|cc|cc|cc|}
\hline \multicolumn{10}{|c|}{ IAF E ALTURA MÉDIA DAS PLANTAS } \\
\hline & & \multicolumn{2}{|c|}{ Parcela I } & \multicolumn{2}{c|}{ Parcela II } & \multicolumn{2}{c|}{ Parcela III } \\
\hline data & idade & $\begin{array}{c}\text { soma } \\
\text { térmica }\end{array}$ & $\begin{array}{c}\text { iaf } \\
\left(\mathrm{m}^{2} / \mathrm{m}^{2}\right)\end{array}$ & $\begin{array}{c}\text { altura } \\
(\mathrm{cm})\end{array}$ & $\begin{array}{c}\text { iaf } \\
\left(\mathrm{m}^{2} / \mathrm{m}^{2}\right)\end{array}$ & $\begin{array}{c}\text { altura } \\
(\mathrm{cm})\end{array}$ & $\begin{array}{c}\text { iaf } \\
\left(\mathrm{m}^{2} / \mathrm{m}^{2}\right)\end{array}$ & $\begin{array}{c}\text { altura } \\
(\mathrm{cm})\end{array}$ \\
\hline 10/abr & 1 & 14,15 & & & & & & \\
19/mai & 40 & 462,75 & 1,20 & & 1,41 & & 1,19 & \\
26/mai & 47 & 515,50 & 1,91 & 52,40 & 2,05 & 57,20 & 1,93 & 53,20 \\
31/mai & 52 & 558,20 & 2,39 & 63,40 & 2,50 & 69,60 & 2,23 & 60,00 \\
7/jun & 59 & 616,75 & 3,10 & 69,00 & 3,29 & 82,00 & 3,24 & 75,00 \\
21/jun & 73 & 738,95 & 3,95 & 126,00 & 3,97 & 136,00 & 3,99 & 136,00 \\
4/jul & 86 & 861,10 & 4,10 & 171,00 & 4,26 & 173,80 & 4,20 & 178,60 \\
14/jul & 96 & 952,90 & 3,88 & 172,20 & 4,16 & 174,40 & 4,23 & 184,75 \\
26/jul & 108 & 1069,45 & 3,89 & 172,20 & 4,04 & 179,60 & 4,19 & 184,75 \\
8/ago & 121 & 1206,35 & 3,76 & 172,20 & 3,85 & 179,60 & 3,86 & 184,75 \\
14/ago & 127 & 1277,25 & 3,53 & 172,20 & 3,52 & 179,60 & 3,70 & 184,75 \\
28/ago & 141 & 1431,60 & 2,96 & 172,20 & 2,90 & 179,60 & 2,96 & 184,75 \\
12/set & 156 & 1595,05 & & & & & & \\
\hline
\end{tabular}


APÊNDICE 4- Manejo da irrigação 
MANEJO DA IRRIGAÇÃO - PARCELA I - $18 \times 18$

precipitação: $3 \mathrm{~mm} / \mathrm{h}$

Fator $p$ : estabelecimento $=0,4$ demais fases $=0,62$

$\mathrm{Kp}=0,8$

Capacidade de Armazenamento do Solo: $\quad 16 \mathrm{~mm}$ até $15 \mathrm{~cm}$ profundidade $29 \mathrm{~mm}$ até $30 \mathrm{~cm}$ profundidade

\begin{tabular}{|c|c|c|c|c|c|c|c|c|}
\hline DATA & ETo & $\mathrm{Kc}$ & ETPC & $\begin{array}{l}\text { Profundidade } \\
\text { de Raizes }(m)\end{array}$ & $\begin{array}{l}\text { Chuva } \\
\text { (mm) }\end{array}$ & $\begin{array}{l}\text { Irrigação } \\
\text { (mm) }\end{array}$ & $\begin{array}{l}\text { Saldo } \\
(\mathrm{mm})\end{array}$ & $\begin{array}{l}\text { Deficit } \\
\text { (mm) }\end{array}$ \\
\hline $1 /$ mai & 4,00 & 0,3 & 0,96 & 0.1 & 0,00 & 2,76 & 16,00 & 0,00 \\
\hline $2 /$ mai & 4,45 & 0,3 & 1,07 & 0,1 & 0,00 & & 14,93 & 1,07 \\
\hline $3 / \mathrm{mai}$ & 4,09 & 0,3 & 0,98 & 0,1 & 0,00 & & 13,95 & 2,05 \\
\hline 4/mai & 1,94 & 0,3 & 0,47 & 0,1 & 0,00 & & 13,48 & 2,52 \\
\hline $5 / \mathrm{mai}$ & 3,06 & 0,3 & 0,73 & 0,1 & 0,40 & & 13,15 & 2,85 \\
\hline $6 /$ mai & 0,26 & 0,3 & 0,06 & 0,1 & 7,50 & & 16,00 & 0,00 \\
\hline $7 / \mathrm{mai}$ & 1,14 & 0,3 & 0,27 & 0,1 & 0,50 & & 16,00 & 0,00 \\
\hline $8 / \mathrm{mai}$ & 2,58 & 0,3 & 0,62 & 0,1 & 0,00 & & 15,38 & 0,62 \\
\hline $9 /$ mai & 3,54 & 0,3 & 0,85 & 0,1 & 5,30 & & 16,00 & 0,00 \\
\hline 10/mai & 0,68 & 0,3 & 0,16 & 0,1 & 15,20 & & 29,00 & 0,00 \\
\hline $11 /$ mai & 0,62 & 0,7 & 0,35 & 0,3 & 0,00 & 2,93 & 29,00 & 0,00 \\
\hline $12 /$ mai & 3,22 & 0,7 & 1,80 & 0,3 & 0,00 & 2,87 & 29,00 & 0,00 \\
\hline 13/mai & 3,34 & 0,7 & 1,87 & 0,3 & 0,00 & 2,61 & 29,00 & 0,00 \\
\hline $14 /$ mai & 3,02 & 0,7 & 1,69 & 0,3 & 0,00 & & 27,31 & 1,69 \\
\hline 15/mai & 3,11 & 0,7 & 1,74 & 0,3 & 0,00 & & 25,57 & 3,43 \\
\hline 16/mai & 4,97 & 0,7 & 2,78 & 0,3 & 30,60 & & 29,00 & 0,00 \\
\hline 17/mai & 3,19 & 0,7 & 1,79 & 0,3 & 0,00 & & 27,21 & 1,79 \\
\hline 18/mai & 2,12 & 0,7 & 1,19 & 0,3 & 4,50 & & 29,00 & 0,00 \\
\hline $19 /$ mai & 4,63 & 0,7 & 2,59 & 0,3 & 0,00 & & 26,41 & 2,59 \\
\hline 20/mai & 2,56 & 0,7 & 1,43 & 0,3 & 0,20 & & 25,17 & 3,83 \\
\hline $21 / \mathrm{mai}$ & 1,26 & 0,7 & 0,71 & 0,3 & 0,00 & & 24,47 & 4,53 \\
\hline $22 / \mathrm{mai}$ & 2,31 & 0,7 & 1,29 & 0,3 & 0,00 & & 23,17 & 5,83 \\
\hline 23/mai & 2,35 & 0,7 & 1,32 & 0,3 & 0,00 & & 21,86 & 7,14 \\
\hline 24/mai & 2,08 & 0,7 & 1,16 & 0,3 & 0,00 & 2,8 & 23,49 & 5,51 \\
\hline 25/mai & 2,46 & 0,7 & 1,38 & 0,3 & 0,00 & & 22,12 & 6,88 \\
\hline 26/mai & 4,26 & 0,7 & 2,39 & 0,3 & 0,00 & & 19,73 & 9,27 \\
\hline 27/mai & 2,66 & 0,7 & 1,49 & 0,3 & 0,00 & 5,6 & 23,84 & 5,16 \\
\hline 28/mai & 2,26 & 0,7 & 1,27 & 0,3 & 0,00 & & 22,58 & 6,42 \\
\hline 29/mai & 1,76 & 0,7 & 0,99 & 0,3 & 0,00 & & 21,59 & 7,41 \\
\hline 30/mai & 3,12 & 0,7 & 1,75 & 0,3 & 0,00 & & 19,84 & 9,16 \\
\hline $31 /$ mai & 2,85 & 0,7 & 1,60 & 0,3 & 0,00 & & 18,25 & 10,75 \\
\hline 1/jun & 2,94 & 0,7 & 1,65 & 0,3 & 0,00 & 1,4 & 18,00 & 11,00 \\
\hline $2 /$ jun & 3,57 & 0,7 & 2,00 & 0,3 & 0,00 & & 16,00 & 13,00 \\
\hline 3/jun & 2,98 & 0.7 & 1,67 & 0,3 & 0,00 & 5,6 & 19,93 & 9,07 \\
\hline 4/jun & 3,60 & 0,7 & 2,02 & 0,3 & 0,00 & & 17,92 & 11,08 \\
\hline 5/jun & 1,36 & 0,7 & 0,76 & 0,3 & 0,00 & & 17,15 & 11,85 \\
\hline 6/jun & 3,26 & 0,7 & 1,83 & 0,3 & 0,00 & 13,5 & 28,83 & 0,17 \\
\hline 7/jun & 3,50 & 0,7 & 1,96 & 0,3 & 0,00 & & 26,87 & 2,13 \\
\hline 8/jun & 1,80 & 0,7 & 1,01 & 0,3 & 0,00 & 3 & 28,86 & 0,14 \\
\hline 9/jun & 5,06 & 0,7 & 2,83 & 0,3 & 0,00 & & 26,03 & 2,97 \\
\hline 10/jun & 3,97 & 0,7 & 2,22 & 0,3 & 0,00 & & 23,80 & 5,20 \\
\hline $11 /$ jun & 3,27 & 0,7 & 1,83 & 0,3 & 0,00 & & 21,97 & 7,03 \\
\hline $12 /$ jun & 2,64 & 0,7 & 1,48 & 0,3 & 0,00 & & 20,49 & 8,51 \\
\hline 13/jun & 2,44 & 0,7 & 1,37 & 0,3 & 0,00 & 3 & 22,13 & 6,87 \\
\hline $14 /$ jun & 3,22 & 0,7 & 1,80 & 0,3 & 0,00 & & 20,32 & 8,68 \\
\hline $15 / j$ un & 3,00 & 0,7 & 1,68 & 0,3 & 0,00 & & 18,64 & 10,36 \\
\hline 16/jun & 3,82 & 0,7 & 2,14 & 0,3 & 0,00 & & 16,51 & 12,49 \\
\hline 17 jun & 0,49 & 0,7 & 0,27 & 0,3 & 2,70 & & 18,93 & 10,07 \\
\hline 18/jun & 0,99 & 0,7 & 0,55 & 0,3 & 10,20 & & 28,58 & 0,42 \\
\hline 19/jun & 2,40 & 1,1 & 2,11 & 0,3 & 0,00 & & 26,46 & 2,54 \\
\hline
\end{tabular}




\begin{tabular}{|c|c|c|c|c|c|c|c|c|}
\hline DATA & ETo & $\mathrm{Kc}$ & ETPc & $\begin{array}{l}\text { Profundidade } \\
\text { de Raizes }(m)\end{array}$ & $\begin{array}{l}\text { Chuva } \\
\text { (mm) }\end{array}$ & $\begin{array}{c}\text { Irrigação } \\
(\mathrm{mm})\end{array}$ & $\begin{array}{l}\text { Saldo } \\
\text { (mm) }\end{array}$ & $\begin{array}{l}\text { Deficit } \\
(\mathrm{mm})\end{array}$ \\
\hline $20 / j u n$ & 3,00 & 1,1 & 2,64 & 0,3 & 0,00 & & 23,82 & 5,18 \\
\hline 21/jun & 1,64 & 1,1 & 1,44 & 0,3 & 0,00 & 3 & 25,38 & 3,62 \\
\hline 22/jun & 2,12 & 1,1 & 1,87 & 0,3 & 0,00 & 3 & 26,52 & 2,48 \\
\hline 23/jun & 3,16 & 1,1 & 2,78 & 0,3 & 0,00 & & 23,74 & 5,26 \\
\hline 24/jun & 3,99 & 1,1 & 3,51 & 0,3 & 0,00 & & 20,22 & 8,78 \\
\hline $25 /$ jun & 2,17 & 1,1 & 1,91 & 0,3 & 10,60 & & 28,91 & 0,09 \\
\hline 26/jun & 1,82 & 1,1 & 1,60 & 0,3 & 0,00 & & 27,31 & 1,69 \\
\hline 27/jun & 2,86 & 1,1 & 2,52 & 0,3 & 0,00 & & 24,80 & 4,20 \\
\hline 28/jun & 2,98 & 1,1 & 2,62 & 0,3 & 0,00 & 3 & 25,17 & 3,83 \\
\hline 29/jun & 1,01 & 1,1 & 0,89 & 0,3 & 0,00 & 3 & 27,28 & 1,72 \\
\hline 30/jun & 3,97 & 1,1 & 3,49 & 0,3 & 0.00 & & 23,79 & 5,21 \\
\hline 1/jul & 3,06 & 1,1 & 2,69 & 0,3 & 0,00 & & 21,10 & 7,90 \\
\hline 2/jul & 2,86 & 1,1 & 2,52 & 0,3 & 0,00 & & 18,58 & 10,42 \\
\hline 3/jul & 3,40 & 1,1 & 2,99 & 0,3 & 0,00 & & 15,59 & 13,41 \\
\hline 4/jul & 3,54 & 1,1 & 3,12 & 0,3 & 0,00 & 6 & 18,47 & 10,53 \\
\hline $5 / \mathrm{jul}$ & 3,33 & 1,1 & 2,93 & 0,3 & 0,00 & & 15,54 & 13,46 \\
\hline 6/jul & 3,61 & 1,1 & 3,18 & 0,3 & 0,00 & & 12,37 & 16,63 \\
\hline 7/jul & 4,30 & 1,1 & 3,78 & 0,3 & 0,50 & 6 & 15,08 & 13,92 \\
\hline 8/jul & 0,24 & 1,1 & 0,21 & 0,3 & 7,20 & & 22,07 & 6,93 \\
\hline 9/jul & 2,94 & 1,1 & 2,59 & 0,3 & 44,10 & & 29,00 & 0,00 \\
\hline 10/jul & 0,89 & 1,1 & 0,78 & 0,3 & 1,00 & & 29,22 & $-0,22$ \\
\hline 11/jul & 2,37 & 1,1 & 2,09 & 0,3 & 0,00 & & 27,13 & 1,87 \\
\hline 12/jul & 2,97 & 1,1 & 2,61 & 0,3 & 0,00 & & 24,52 & 4,48 \\
\hline $13 / j u l$ & 1,75 & 1,1 & 1,54 & 0,3 & 0,00 & 3 & 25,98 & 3,02 \\
\hline $14 / j u l$ & 4,17 & 1,1 & 3,67 & 0,3 & 0,00 & & 22,31 & 6,69 \\
\hline $15 / j u l$ & 2,11 & 1,1 & 1,86 & 0,3 & 0,00 & & 20,45 & 8,55 \\
\hline 16/jul & 2,72 & 1,1 & 2,39 & 0,3 & 0,00 & & 18,06 & 10,94 \\
\hline $17 / j u l$ & 3,08 & 1,1 & 2,71 & 0,3 & 0,00 & 3 & 18,35 & 10,65 \\
\hline 18/jul & 3,52 & 1,1 & 3,10 & 0,3 & 0,00 & & 15,25 & 13,75 \\
\hline 19/jul & 4,28 & 1,1 & 3,77 & 0,3 & 0,00 & & 11,48 & 17,52 \\
\hline 20/jul & 1,78 & 1,1 & 1,57 & 0,3 & 0,00 & & 9,92 & 19,08 \\
\hline 21/jul & 1,72 & 1,1 & 1,51 & 0,3 & 5,90 & 3 & 17,30 & 11,70 \\
\hline $22 / j u l$ & 1,28 & 1,1 & 1,13 & 0,3 & 0,00 & & 16,18 & 12,82 \\
\hline 23/jul & 2,28 & 1,1 & 2,01 & 0,3 & 0,00 & & 14,17 & 14,83 \\
\hline 24/jul & 3,32 & 1,1 & 2,92 & 0,3 & 0,00 & 9 & 20,25 & 8,75 \\
\hline $25 / \mathrm{jul}$ & 3,96 & 1,1 & 3,48 & 0,3 & 0,00 & & 16,76 & 12,24 \\
\hline 26/jul & 3,72 & 1,1 & 3,27 & 0,3 & 0,00 & 3 & 16,49 & 12,51 \\
\hline 27/jul & 3,39 & 1,1 & 2,98 & 0,3 & 0,00 & 9 & 22,51 & 6,49 \\
\hline 28/jul & 6,13 & 1,1 & 5,39 & 0,3 & 0,00 & & 17,11 & 11,89 \\
\hline 29/jul & 4,60 & 1,1 & 4,05 & 0,3 & 0,00 & & 13,06 & 15,94 \\
\hline $30 / j u l$ & 2,40 & 1,1 & 2,11 & 0,3 & 0,00 & & 10,95 & 18,05 \\
\hline $31 / j u l$ & 3,94 & 1,1 & 3,47 & 0,3 & 0,00 & 9 & 16,49 & 12,51 \\
\hline 1/ago & 5,10 & 1,1 & 4,49 & 0,3 & 0,00 & 3 & 15,00 & 14,00 \\
\hline 2/ago & 4,66 & 1,1 & 4,10 & 0,3 & 0,00 & & 10,90 & 18,10 \\
\hline 3/ago & 3,14 & 1,1 & 2,76 & 0,3 & 0,00 & 9 & 17,13 & 11,87 \\
\hline 4/ago & 5,08 & 1,1 & 4,47 & 0,3 & 0,90 & & 13,56 & 15,44 \\
\hline 5/ago & 1,92 & 1.1 & 1,69 & 0,3 & 0,30 & & 12,17 & 16,83 \\
\hline 6/ago & 2,76 & 1,1 & 2,43 & 0,3 & 0,00 & & 9,74 & 19,26 \\
\hline 7/ago & 4,04 & 0,9 & 2,91 & 0,3 & 0,00 & 3 & 9,84 & 19,16 \\
\hline 8/ago & 4,16 & 0,9 & 3,00 & 0,3 & 0,00 & 16,5 & 23,34 & 5,66 \\
\hline 9/ago & 5,22 & 0,9 & 3,76 & 0,3 & 0,00 & 3 & 22,58 & 6,42 \\
\hline 10/ago & 4,49 & 0,9 & 3,23 & 0,3 & 0,00 & & 19,35 & 9,65 \\
\hline 11/ago & 5,02 & 0,9 & 3,61 & 0,3 & 0,00 & & 15,74 & 13,26 \\
\hline 12/ago & 5,14 & 0,9 & 3,70 & 0,3 & 0,00 & & 12,03 & 16,97 \\
\hline 13/ago & 4,56 & 0,9 & 3,28 & 0,3 & 0,00 & & 8,75 & 20,25 \\
\hline 14/ago & 5,98 & 0,9 & 4,31 & 0,3 & 0,00 & 3 & 7,45 & 21,55 \\
\hline 15/ago & 6,46 & 0,9 & 4,65 & 0,3 & 0,00 & 9 & 11,79 & 17,21 \\
\hline 16/ago & 3,41 & 0,9 & 2,46 & 0,3 & 0.00 & 9 & 18,34 & 10,66 \\
\hline
\end{tabular}




\begin{tabular}{|c|c|c|c|c|c|c|c|c|}
\hline DATA & ETo & $\mathrm{Kc}$ & ETPC & $\begin{array}{l}\text { Profundidade } \\
\text { de Raizes }(m)\end{array}$ & $\begin{array}{l}\text { Chuva } \\
\text { (mm) }\end{array}$ & $\begin{array}{l}\text { Irrigação } \\
\text { (mm) }\end{array}$ & $\begin{array}{l}\text { Saldo } \\
\text { (mm) }\end{array}$ & $\begin{array}{l}\text { Deficit } \\
(\mathrm{mm})\end{array}$ \\
\hline 17/ago & 4,42 & 0,9 & 3,18 & 0,3 & 0,00 & & 15,16 & 13,84 \\
\hline 18/ago & 5,46 & 0,9 & 3,93 & 0,3 & 0,00 & 15 & 26,23 & 2,77 \\
\hline 19/ago & 5,78 & 0,9 & 4,16 & 0,3 & 0,00 & & 22,06 & 6,94 \\
\hline 20/ago & 4,48 & 0,9 & 3,23 & 0,3 & 0,00 & & 18,84 & 10,16 \\
\hline 21/ago & 4,16 & 0,9 & 3,00 & 0,3 & 0,00 & 3 & 18,84 & 10,16 \\
\hline 22/ago & 3,80 & 0,9 & 2,74 & 0,3 & 0,00 & 15 & 29,00 & 0,00 \\
\hline 23/ago & 5,60 & 0,9 & 4,03 & 0,3 & 0,00 & 3 & 27,97 & 1,03 \\
\hline 24/ago & 5,88 & 0,9 & 4,23 & 0,3 & 0,00 & & 23,73 & 5,27 \\
\hline 25/ago & 5,90 & 0,9 & 4,25 & 0,3 & 0,00 & 16,5 & 29,00 & 0,00 \\
\hline 26/ago & 5,54 & 0,9 & 3,99 & 0,3 & 0,00 & & 25,01 & 3,99 \\
\hline 27lago & 6,08 & 0,9 & 4,38 & 0,3 & 0,00 & & 20,63 & 8,37 \\
\hline 28/ago & 3,61 & 0,9 & 2,60 & 0,3 & 0,00 & 3 & 21,03 & 7,97 \\
\hline 29/ago & 6,11 & 0,9 & 4,40 & 0,3 & 0,00 & & 16,64 & 12,36 \\
\hline 30/ago & 6,90 & 0,9 & 4,97 & 0,3 & 0,00 & & 11,67 & 17,33 \\
\hline $31 /$ ago & 5,60 & 0,9 & 4,03 & 0,3 & 0,00 & & 7,64 & 21,36 \\
\hline $1 /$ set & 7,76 & 0,9 & 5,59 & 0,3 & 0,00 & & 2,05 & 26,95 \\
\hline $2 /$ set & 6,58 & 0,9 & 4,74 & 0,3 & 0,00 & & 0,00 & 29,00 \\
\hline $3 /$ set & 5,66 & 0,9 & 4,08 & 0,3 & 0,00 & & 0,00 & 29,00 \\
\hline 4/set & 5,76 & 0,9 & 4,15 & 0,3 & 0,00 & & 0,00 & 29,00 \\
\hline 5/set & 6,12 & 0,9 & 4,41 & 0,3 & 0,00 & & 0,00 & 29,00 \\
\hline $6 /$ set & 6,06 & 0,9 & 4,36 & 0,3 & 0,00 & & 0,00 & 29,00 \\
\hline $7 /$ set & 5,78 & 0,9 & 4,16 & 0,3 & 0,00 & & 0,00 & 29,00 \\
\hline $8 /$ set & 5,98 & 0,9 & 4,31 & 0,3 & 0,00 & & 0,00 & 29,00 \\
\hline 9/set & 6,28 & 0,9 & 4,52 & 0,3 & 0,00 & & 0,00 & 29,00 \\
\hline $10 /$ set & 6,68 & 0,9 & 4,81 & 0,3 & 0,00 & & 0,00 & 29,00 \\
\hline $11 /$ set & 7,26 & 0,9 & 5,23 & 0,3 & 0,00 & & 0,00 & 29,00 \\
\hline $12 /$ set & 6,07 & 0,9 & 4,37 & 0,3 & 0,00 & & 0,00 & 29,00 \\
\hline $13 /$ set & 3,97 & 0,9 & 2,86 & 0,3 & 0,00 & & 0,00 & 29,00 \\
\hline $14 /$ set & 5,86 & 0,9 & 4,22 & 0,3 & 0,00 & & 0,00 & 29,00 \\
\hline $15 /$ set & 6,31 & 0,9 & 4,54 & 0,3 & 0,00 & & 0,00 & 29,00 \\
\hline $16 /$ set & 7,12 & 0,9 & 5,13 & 0,3 & 0,00 & & 0,00 & 29,00 \\
\hline $17 /$ set & 1,94 & 0,9 & 1,40 & 0,3 & 3,50 & & 0,00 & 29,00 \\
\hline $18 /$ set & 5,54 & 0,9 & 3,99 & 0,3 & 3,90 & & 0,00 & 29,00 \\
\hline $19 /$ set & 6,56 & 0,9 & 4,72 & 0,3 & 5,50 & & 0,00 & 29,00 \\
\hline $20 /$ set & 2,54 & 0,9 & 1,83 & 0,3 & 0,60 & & 0,00 & 29,00 \\
\hline $21 /$ set & 3,50 & 0,9 & 2,52 & 0,3 & 30,00 & & 0,00 & 29,00 \\
\hline
\end{tabular}


MANEJO DA IRRIGAÇÃO - PARCELA II - 12 X 18

precipitação: $4 \mathrm{~mm} / \mathrm{h}$

Fator $p$ : estabelecimento $=0,4 \quad$ demais fases $=0,62$

$\mathrm{Kp}=0,8$

Capacidade de Armazenamento do Solo: $\quad 16 \mathrm{~mm}$ até $15 \mathrm{~cm}$ profundidade $29 \mathrm{~mm}$ até $30 \mathrm{~cm}$ profundidade

\begin{tabular}{|c|c|c|c|c|c|c|c|c|}
\hline DATA & ETo & $\mathrm{Kc}$ & ETPC & $\begin{array}{l}\text { Profundidade } \\
\text { de Raizes (m) }\end{array}$ & $\begin{array}{l}\text { Chuva } \\
(\mathrm{mm})\end{array}$ & $\begin{array}{l}\text { Irrigação } \\
(\mathrm{mm})\end{array}$ & $\begin{array}{l}\text { Saldo } \\
\text { (mm) }\end{array}$ & $\begin{array}{l}\text { Deficit } \\
(\mathrm{mm})\end{array}$ \\
\hline $1 /$ mai & 4,00 & 0,3 & 0,96 & 0,1 & 0,00 & 4,2 & 16,00 & 0,00 \\
\hline $2 / \mathrm{mai}$ & 4,45 & 0,3 & 1,07 & 0,1 & 0,00 & & 14,93 & 1,07 \\
\hline 3/mai & 4,09 & 0,3 & 0,98 & 0,1 & 0,00 & & 13,95 & 2,05 \\
\hline $4 / \mathrm{mai}$ & 1,94 & 0,3 & 0,47 & 0,1 & 0,00 & & 13,48 & 2,52 \\
\hline 5/mai & 3,06 & 0,3 & 0,73 & 0,1 & 0,40 & & 13,15 & 2,85 \\
\hline 6/mai & 0,26 & 0,3 & 0,06 & 0,1 & 7,50 & & 16,00 & 0,00 \\
\hline $7 /$ mai & 1,14 & 0,3 & 0.27 & 0,1 & 0,50 & & 16,00 & 0,00 \\
\hline 8/mai & 2,58 & 0,3 & 0,62 & 0,1 & 0,00 & & 15,38 & 0,62 \\
\hline 9/mai & 3,54 & 0.3 & 0,85 & 0,1 & 5,30 & & 16,00 & 0,00 \\
\hline $10 /$ mai & 0,68 & 0,3 & 0,16 & 0,1 & 15,20 & 4,1 & 29,00 & 0,00 \\
\hline 11/mai & 0,62 & 0,7 & 0,35 & 0,3 & 0,00 & 4 & 29,00 & 0,00 \\
\hline $12 /$ mai & 3,22 & 0,7 & 1,8 & 0,3 & 0,00 & 4 & 29,00 & 0,00 \\
\hline $13 /$ mai & 3,34 & 0,7 & 1,87 & 0,3 & 0,00 & 4 & 29,00 & 0,00 \\
\hline $14 /$ mai & 3,02 & 0,7 & 1,69 & 0,3 & 0,00 & & 27,31 & 1,69 \\
\hline $15 /$ mai & 3,11 & 0,7 & 1,74 & 0,3 & 0,00 & & 25,57 & 3,43 \\
\hline $16 /$ mai & 4,97 & 0,7 & 2,78 & 0,3 & 30,60 & & 29,00 & 0,00 \\
\hline 17/mai & 3,19 & 0,7 & 1,79 & 0,3 & 0,00 & & 27,21 & 1,79 \\
\hline 18/mai & 2,12 & 0,7 & 1,19 & 0,3 & 4,50 & & 29,00 & 0,00 \\
\hline $19 /$ mai & 4,63 & 0,7 & 2,59 & 0,3 & 0,00 & & 26,41 & 2,59 \\
\hline 20/mai & 2,56 & 0,7 & 1,43 & 0,3 & 0,20 & & 25,17 & 3,83 \\
\hline $21 / \mathrm{mai}$ & 1,26 & 0,7 & 0,71 & 0.3 & 0,00 & & 24,47 & 4,53 \\
\hline $22 / \mathrm{mai}$ & 2,31 & 0,7 & 1,29 & 0,3 & 0,00 & & 23,17 & 5,83 \\
\hline 23/mai & 2,35 & 0,7 & 1,32 & 0,3 & 0,00 & & 21,86 & 7,14 \\
\hline $24 /$ mai & 2,08 & 0,7 & 1,16 & 0,3 & 0,00 & 4 & 24,69 & 4,31 \\
\hline $25 /$ mai & 2,46 & 0,7 & 1,38 & 0,3 & 0,00 & & 23,32 & 5,68 \\
\hline $26 /$ mai & 4,26 & 0,7 & 2,39 & 0,3 & 0,00 & & 20,93 & 8,07 \\
\hline $27 /$ mai & 2,66 & 0,7 & 1,49 & 0,3 & 0,00 & 6 & 25,44 & 3,56 \\
\hline 28/mai & 2,26 & 0,7 & 1,27 & 0,3 & 0,00 & & 24,18 & 4,82 \\
\hline 29/mai & 1,76 & 0,7 & 0,99 & 0,3 & 0,00 & & 23,19 & 5,81 \\
\hline 30/mai & 3,12 & 0,7 & 1,75 & 0,3 & 0,00 & & 21,44 & 7,56 \\
\hline $31 / \mathrm{mai}$ & 2,85 & 0,7 & 1,6 & 0,3 & 0,00 & & 19,85 & 9,15 \\
\hline $1 /$ jun & 2,94 & 0,7 & 1,65 & 0,3 & 0,00 & 2 & 20,20 & 8,80 \\
\hline 2/jun & 3,57 & 0,7 & 2 & 0,3 & 0,00 & & 18,20 & 10,80 \\
\hline 3/jun & 2,98 & 0,7 & 1,67 & 0,3 & 0,00 & 8 & 24,53 & 4,47 \\
\hline 4/jun & 3,60 & 0,7 & 2,02 & 0,3 & 0,00 & & 22,52 & 6,48 \\
\hline 5/jun & 1,36 & 0,7 & 0,76 & 0,3 & 0,00 & & 21,75 & 7,25 \\
\hline 6/jun & 3,26 & 0,7 & 1,83 & 0,3 & 0,00 & 18 & 29,00 & 0,00 \\
\hline $7 /$ jun & 3,50 & 0,7 & 1,96 & 0,3 & 0,00 & & 27,04 & 1,96 \\
\hline 8/jun & 1,80 & 0,7 & 1,01 & 0,3 & 0,00 & 4 & 29,00 & 0,00 \\
\hline 9/jun & 5,06 & 0,7 & 2,83 & 0,3 & 0,00 & & 26,17 & 2,83 \\
\hline 10/jun & 3,97 & 0,7 & 2,22 & 0,3 & 0,00 & & 23,94 & 5,06 \\
\hline $11 /$ jun & 3,27 & 0,7 & 1,83 & 0,3 & 0,00 & & 22,11 & 6,89 \\
\hline 12/jun & 2,64 & 0,7 & 1,48 & 0,3 & 0,00 & & 20,63 & 8,37 \\
\hline 13/jun & 2,44 & 0,7 & 1,37 & 0,3 & 0,00 & 4 & 23,27 & 5,73 \\
\hline 14/jun & 3,22 & 0,7 & 1,8 & 0,3 & 0,00 & & 21,46 & 7,54 \\
\hline 15/jun & 3,00 & 0,7 & 1,68 & 0,3 & 0,00 & & 19,78 & 9,22 \\
\hline $16 / j$ un & 3,82 & 0,7 & 2,14 & 0,3 & 0,00 & & 17,64 & 11,36 \\
\hline $17 /$ jun & 0,49 & 0,7 & 0,27 & 0,3 & 2,70 & & 20,07 & 8,93 \\
\hline
\end{tabular}




\begin{tabular}{|c|c|c|c|c|c|c|c|c|}
\hline DATA & ETO & $\mathrm{Kc}$ & ETPc & $\begin{array}{l}\text { Profundidade } \\
\text { de Raizes (m) }\end{array}$ & $\begin{array}{l}\text { Chuva } \\
(\mathrm{mm})\end{array}$ & $\begin{array}{c}\text { Irrigaçãa } \\
(\mathrm{mm})\end{array}$ & $\begin{array}{l}\text { Saldo } \\
(\mathrm{mm})\end{array}$ & $\begin{array}{l}\text { Deficit } \\
(\mathrm{mm})\end{array}$ \\
\hline 18/jun & 0,99 & 0,7 & 0,55 & 0,3 & 10,20 & & 29,00 & 0,00 \\
\hline 19/jun & 2,40 & 1,1 & 2,11 & 0,3 & 0,00 & & 26,89 & 2,11 \\
\hline 20/jun & 3,00 & 1,1 & 2,64 & 0,3 & 0,00 & & 24,25 & 4,75 \\
\hline 21/jun & 1,64 & 1,1 & 1,44 & 0,3 & 0,00 & 4 & 26,80 & 2,20 \\
\hline 22/jun & 2,12 & 1,1 & 1,87 & 0,3 & 0,00 & 4 & 28,94 & 0,06 \\
\hline 23/jun & 3,16 & 1,1 & 2,78 & 0,3 & 0,00 & & 26,16 & 2,84 \\
\hline 24/jun & 3,99 & 1,1 & 3,51 & 0,3 & 0,00 & & 22,65 & 6,35 \\
\hline 25/jun & 2,17 & 1,1 & 1,91 & 0,3 & 10,60 & & 29,00 & 0,00 \\
\hline 26/jun & 1,82 & 1,1 & 1,6 & 0,3 & 0,00 & & 27,40 & 1,60 \\
\hline 27/jun & 2,86 & 1,1 & 2,52 & 0,3 & 0,00 & & 24,88 & 4,12 \\
\hline 28/jun & 2,98 & 1,1 & 2,62 & 0,3 & 0,00 & 4 & 26,26 & 2,74 \\
\hline 29/jun & 1,01 & 1,1 & 0,89 & 0,3 & 0,00 & & 25,37 & 3,63 \\
\hline 30/jun & 3,97 & 1,1 & 3,49 & 0,3 & 0,00 & & 21,88 & 7,12 \\
\hline 1/jul & 3,06 & 1,1 & 2,69 & 0,3 & 0,00 & & 19,18 & 9,82 \\
\hline 2/jul & 2,86 & 1,1 & 2,52 & 0,3 & 0,00 & & 16,67 & 12,33 \\
\hline 3/jul & 3,40 & 1,1 & 2,99 & 0,3 & 0,00 & & 13,68 & 15,32 \\
\hline 4/jul & 3,54 & 1,1 & 3,12 & 0,3 & 0,00 & 8 & 18,56 & 10,44 \\
\hline 5/jul & 3,33 & 1,1 & 2,93 & 0,3 & 0,00 & & 15,63 & 13,37 \\
\hline 6/jul & 3,61 & 1,1 & 3,18 & 0,3 & 0,00 & & 12,45 & 16,55 \\
\hline $7 / j u l$ & 4,30 & 1,1 & 3,78 & 0,3 & 0,50 & 8 & 17,17 & 11,83 \\
\hline 8/jul & 0,24 & 1,1 & 0,21 & 0,3 & 7,20 & & 24,16 & 4,84 \\
\hline 9/jul & 2,94 & 1,1 & 2,59 & 0,3 & 44,10 & & 29,00 & 0,00 \\
\hline 10/jul & 0,89 & 1,1 & 0,78 & 0,3 & 1,00 & & 29,00 & 0,00 \\
\hline $11 / \mathrm{jul}$ & 2,37 & 1,1 & 2,09 & 0,3 & 0,00 & & 26,91 & 2,09 \\
\hline $12 / \mathrm{jul}$ & 2,97 & 1,1 & 2,61 & 0,3 & 0,00 & & 24,30 & 4,70 \\
\hline $13 / \mathrm{jul}$ & 1,75 & 1,1 & 1,54 & 0,3 & 0,00 & 4 & 26,76 & 2,24 \\
\hline 14/jul & 4,17 & 1,1 & 3,67 & 0,3 & 0,00 & & 23,09 & 5,91 \\
\hline 15/jul & 2,11 & 1,1 & 1,86 & 0,3 & 0,00 & & 21,23 & 7,77 \\
\hline 16/jul & 2,72 & 1,1 & 2,39 & 0,3 & 0,00 & & 18,84 & 10,16 \\
\hline 17/jul & 3,08 & 1,1 & 2,71 & 0,3 & 0,00 & 4 & 20,13 & 8,87 \\
\hline 18/jul & 3,52 & 1,1 & 3,1 & 0,3 & 0,00 & & 17,03 & 11,97 \\
\hline 19/jul & 4,28 & 1,1 & 3,77 & 0,3 & 0,00 & & 13,27 & 15,73 \\
\hline 20/jul & 1,78 & 1,1 & 1,57 & 0,3 & 0,00 & & 11,70 & 17,30 \\
\hline 21/jul & 1,72 & 1,1 & 1,51 & 0,3 & 5,90 & 4 & 20,09 & 8,91 \\
\hline $22 / j u l$ & 1,28 & 1,1 & 1,13 & 0,3 & 0,00 & & 18,96 & 10,04 \\
\hline 23/jul & 2,28 & 1,1 & 2,01 & 0,3 & 0,00 & & 16,95 & 12,05 \\
\hline $24 / j u l$ & 3,32 & 1,1 & 2,92 & 0,3 & 0,00 & 12 & 26,03 & 2,97 \\
\hline $25 / \mathrm{jul}$ & 3,96 & 1,1 & 3,48 & 0,3 & 0,00 & & 22,55 & 6,45 \\
\hline $26 / \mathrm{jul}$ & 3,72 & 1,1 & 3,27 & 0,3 & 0,00 & 4 & 23,27 & 5,73 \\
\hline 27/jul & 3,39 & 1,1 & 2,98 & 0,3 & 0,00 & 8 & 28,29 & 0,71 \\
\hline 28/jul & 6,13 & 1,1 & 5,39 & 0,3 & 0,00 & & 22,90 & 6,10 \\
\hline 29/jul & 4,60 & 1,1 & 4,05 & 0,3 & 0,00 & & 18,85 & 10,15 \\
\hline 30/jul & 2,40 & 1,1 & 2,11 & 0,3 & 0,00 & & 16,74 & 12,26 \\
\hline $31 / j u l$ & 3,94 & 1,1 & 3,47 & 0,3 & 0,00 & 12 & 25,27 & 3,73 \\
\hline 1/ago & 5,10 & 1,1 & 4,49 & 0,3 & 0,00 & 4 & 24,78 & 4,22 \\
\hline 2/ago & 4,66 & 1,1 & 4,1 & 0,3 & 0,00 & & 20,68 & 8,32 \\
\hline 3/ago & 3,14 & 1,1 & 2,76 & 0,3 & 0,00 & 12 & 29,00 & 0,00 \\
\hline 4/ago & 5,08 & 1,1 & 4,47 & 0,3 & 0,90 & & 25,43 & 3,57 \\
\hline 5/ago & 1,92 & 1,1 & 1,69 & 0.3 & 0,30 & & 24,04 & 4,96 \\
\hline 6/ago & 2,76 & 1,1 & 2,43 & 0,3 & 0,00 & & 21,61 & 7,39 \\
\hline 7/ago & 4,04 & 0,9 & 2,91 & 0,3 & 0,00 & 4 & 22,70 & 6,30 \\
\hline 8/ago & 4,16 & 0,9 & 3 & 0,3 & 0,00 & & 19,71 & 9,29 \\
\hline 9/ago & 5,22 & 0,9 & 3,76 & 0,3 & 0,00 & 4 & 19,95 & 9,05 \\
\hline 10/ago & 4,49 & 0,9 & 3,23 & 0,3 & 0,00 & & 16,72 & 12,28 \\
\hline 11/ago & 5,02 & 0,9 & 3,61 & 0,3 & 0,00 & & 13,10 & 15,90 \\
\hline 12/ago & 5,14 & 0,9 & 3,7 & 0,3 & 0,00 & & 9,40 & 19,60 \\
\hline 13/ago & 4,56 & 0,9 & 3,28 & 0,3 & 0,00 & & 6,12 & 22,88 \\
\hline 14/ago & 5,98 & 0,9 & 4,31 & 0,3 & 0,00 & 4 & 5,81 & 23,19 \\
\hline
\end{tabular}




\begin{tabular}{|c|c|c|c|c|c|c|c|c|}
\hline DATA & ETo & $\mathrm{Kc}$ & ETPC & $\begin{array}{l}\text { Profundidade } \\
\text { de Raizes (m) }\end{array}$ & $\begin{array}{c}\text { Chuva } \\
(\mathrm{mm})\end{array}$ & $\begin{array}{c}\text { Irrigação } \\
(\mathrm{mm})\end{array}$ & $\begin{array}{l}\text { Saldo } \\
(\mathrm{mm})\end{array}$ & $\begin{array}{c}\text { Deficit } \\
(\mathrm{mm})\end{array}$ \\
\hline 15/ago & 6,46 & 0,9 & 4,65 & 0,3 & 0,00 & 12 & 13,16 & 15,84 \\
\hline 16/ago & 3,41 & 0,9 & 2,46 & 0,3 & 0,00 & 8 & 18,71 & 10,29 \\
\hline 17/ago & 4,42 & 0,9 & 3,18 & 0,3 & 0,00 & & 15,52 & 13,48 \\
\hline 18/ago & 5,46 & 0,9 & 3,93 & 0,3 & 0,00 & 20 & 29,00 & 0,00 \\
\hline 19/ago & 5,78 & 0,9 & 4,16 & 0,3 & 0,00 & & 24,84 & 4,16 \\
\hline 20/ago & 4,48 & 0,9 & 3,23 & 0,3 & 0,00 & & 21,61 & 7,39 \\
\hline 21/ago & 4,16 & 0,9 & 3 & 0,3 & 0,00 & 4 & 22,62 & 6,38 \\
\hline 22/ago & 3,80 & 0,9 & 2,74 & 0,3 & 0,00 & 20 & 29,00 & 0,00 \\
\hline 23/ago & 5,60 & 0,9 & 4,03 & 0,3 & 0,00 & 4 & 28,97 & 0,03 \\
\hline 24/ago & 5,88 & 0,9 & 4,23 & 0,3 & 0,00 & & 24,73 & 4,27 \\
\hline 25 /ago & 5,90 & 0,9 & 4,25 & 0,3 & 0,00 & 22 & 29,00 & 0,00 \\
\hline 26/ago & 5,54 & 0,9 & 3,99 & 0,3 & 0,00 & & 25,01 & 3,99 \\
\hline 27/ago & 6,08 & 0,9 & 4,38 & 0,3 & 0,00 & & 20,63 & 8,37 \\
\hline 28/ago & 3,61 & 0,9 & 2,6 & 0,3 & 0,00 & 4 & 22,03 & 6,97 \\
\hline 29/ago & 6,11 & 0,9 & 4,4 & 1,3 & 0,00 & & 17,64 & 11,36 \\
\hline 30/ago & 6,90 & 0,9 & 4,97 & 2,3 & 0,00 & & 12,67 & 16,33 \\
\hline 31/ago & 5,60 & 0,9 & 4,03 & 3,3 & 0,00 & & 8,64 & 20,36 \\
\hline $1 /$ set & 7,76 & 0,9 & 5,59 & 4,3 & 0,00 & & 3,05 & 25,95 \\
\hline 2/set & 6,58 & 0,9 & 4,74 & 5,3 & 0,00 & & 0,00 & 29,00 \\
\hline $3 /$ set & 5,66 & 0,9 & 4,08 & 6,3 & 0,00 & & 0,00 & 29,00 \\
\hline 4/set & 5,76 & 0,9 & 4,15 & 7,3 & 0,00 & & 0,00 & 29,00 \\
\hline $5 /$ set & 6,12 & 0,9 & 4,41 & 8,3 & 0,00 & & 0,00 & 29,00 \\
\hline 6/set & 6,06 & 0,9 & 4,36 & 9,3 & 0,00 & & 0,00 & 29,00 \\
\hline 7/set & 5,78 & 0,9 & 4,16 & 10,3 & 0,00 & & 0,00 & 29,00 \\
\hline 8/set & 5,98 & 0,9 & 4,31 & 11,3 & 0,00 & & 0,00 & 29,00 \\
\hline 9/set & 6,28 & 0,9 & 4,52 & 12,3 & 0,00 & & 0,00 & 29,00 \\
\hline $10 /$ set & 6,68 & 0,9 & 4,81 & 13,3 & 0,00 & & 0,00 & 29,00 \\
\hline $11 /$ set & 7,26 & 0,9 & 5,23 & 14,3 & 0,00 & & 0,00 & 29,00 \\
\hline $12 /$ set & 6,07 & 0,9 & 4,37 & 15,3 & 0,00 & & 0,00 & 29,00 \\
\hline 13/set & 3,97 & 0,9 & 2,86 & 16,3 & 0,00 & & 0,00 & 29,00 \\
\hline 14/set & 5,86 & 0,9 & 4,22 & 17,3 & 0,00 & & 0,00 & 29,00 \\
\hline $15 /$ set & 6,31 & 0,9 & 4,54 & 18,3 & 0,00 & & 0,00 & 29,00 \\
\hline $16 /$ set & 7,12 & 0,9 & 5,13 & 19,3 & 0,00 & & 0,00 & 29,00 \\
\hline $17 /$ set & 1,94 & 0,9 & 1,4 & 20,3 & 3,50 & & 0,00 & 29,00 \\
\hline $18 /$ set & 5,54 & 0,9 & 3,99 & 21,3 & 3,90 & & 0,00 & 29,00 \\
\hline $19 /$ set & 6,56 & 0,9 & 4,72 & 22,3 & 5,50 & & 0,00 & 29,00 \\
\hline $20 /$ set & 2,54 & 0,9 & 1,83 & 23,3 & 0,60 & & 0,00 & 29,00 \\
\hline $21 /$ set & 3,50 & 0,9 & 2,52 & 24,3 & 0,00 & & 0,00 & 29,00 \\
\hline
\end{tabular}


MANEJO DA IRRIGAÇÃO - PARCELA III - $6 \times 12$

precipitação: $9 \mathrm{~mm} / \mathrm{h}$

Fator $p$ : estabelecimento $=0,4 \quad$ demais fases $=0,62$

$\mathrm{Kp}=0,8$

Capacidade de Armazenamento do Solo : $\quad 16 \mathrm{~mm}$ até $15 \mathrm{~cm}$ profundidade $29 \mathrm{~mm}$ até $30 \mathrm{~cm}$ profundidade

\begin{tabular}{|c|c|c|c|c|c|c|c|c|}
\hline DATA & ETo & $\mathrm{Kc}$ & ETPC & $\begin{array}{l}\text { Profundidade } \\
\text { de Raízes }(\mathrm{m})\end{array}$ & $\begin{array}{l}\text { Chuva } \\
(\mathrm{mm})\end{array}$ & $\begin{array}{c}\text { Irrigaçāo } \\
\text { (mm) }\end{array}$ & $\begin{array}{l}\text { Saldo } \\
(\mathrm{mm})\end{array}$ & $\begin{array}{l}\text { Deficit } \\
(\mathrm{mm})\end{array}$ \\
\hline $1 /$ mai & 4,00 & 0,3 & 0,96 & 0,1 & 0,00 & 9,69 & 16,00 & 0,00 \\
\hline $2 / \mathrm{mai}$ & 4,45 & 0,3 & 1,07 & 0,1 & 0,00 & & 14,93 & 1,07 \\
\hline $3 /$ mai & 4,09 & 0,3 & 0,98 & 0,1 & 0,00 & 10,5 & 16,00 & 0,00 \\
\hline $4 / \mathrm{mai}$ & 1,94 & 0,3 & 0,47 & 0,1 & 0,00 & & 15,53 & 0,47 \\
\hline 5/mai & 3,06 & 0,3 & 0,73 & 0,1 & 0,40 & 10,5 & 16,00 & 0,00 \\
\hline 6/mai & 0,26 & 0,3 & 0,06 & 0,1 & 7,50 & & 16,00 & 0,00 \\
\hline 7/mai & 1,14 & 0,3 & 0,27 & 0,1 & 0,50 & & 16,00 & 0,00 \\
\hline 8/mai & 2,58 & 0,3 & 0,62 & 0,1 & 0,00 & & 15,38 & 0,62 \\
\hline 9/mai & 3,54 & 0,3 & 0,85 & 0,1 & 5,30 & & 16,00 & 0,00 \\
\hline 10/mai & 0,68 & 0,3 & 0,16 & 0,1 & 15,20 & 20,7 & 16,00 & 0,00 \\
\hline $11 /$ mai & 0,62 & 0,7 & 0,35 & 0,3 & 0,00 & 8,88 & 24,53 & 4,47 \\
\hline $12 /$ mai & 3,22 & 0,7 & 1,8 & 0,3 & 0,00 & 9,1 & 29,00 & 0,00 \\
\hline 13/mai & 3,34 & 0,7 & 1,87 & 0,3 & 0,00 & 9,14 & 29,00 & 0,00 \\
\hline 14/mai & 3,02 & 0,7 & 1,69 & 0,3 & 0,00 & & 27,31 & 1,69 \\
\hline 15/mai & 3,11 & 0,7 & 1,74 & 0,3 & 0,00 & & 25,57 & 3,43 \\
\hline 16/mai & 4,97 & 0,7 & 2,78 & 0,3 & 30,60 & & 29,00 & 0,00 \\
\hline 17/mai & 3,19 & 0,7 & 1,79 & 0,3 & 0,00 & & 27,21 & 1,79 \\
\hline 18/mai & 2,12 & 0,7 & 1,19 & 0,3 & 4,50 & & 29,00 & 0,00 \\
\hline 19/mai & 4,63 & 0,7 & 2,59 & 0,3 & 0,00 & & 26,41 & 2,59 \\
\hline 20/mai & 2,56 & 0,7 & 1,43 & 0,3 & 0,20 & & 25,17 & 3,83 \\
\hline 21/mai & 1,26 & 0,7 & 0,71 & 0,3 & 0,00 & & 24,47 & 4,53 \\
\hline $22 /$ mai & 2,31 & 0,7 & 1,29 & 0,3 & 0,00 & & 23,17 & 5,83 \\
\hline 23/mai & 2,35 & 0,7 & 1,32 & 0,3 & 0,00 & & 21,86 & 7,14 \\
\hline 24/mai & 2,08 & 0,7 & 1,16 & 0,3 & 0,00 & 9 & 29,00 & 0,00 \\
\hline 25/mai & 2,46 & 0,7 & 1,38 & 0,3 & 0,00 & & 27,62 & 1,38 \\
\hline 26/mai & 4,26 & 0,7 & 2,39 & 0,3 & 0,00 & & 25,24 & 3,76 \\
\hline $27 /$ mai & 2,66 & 0,7 & 1,49 & 0,3 & 0,00 & & 23,75 & 5,25 \\
\hline 28/mai & 2,26 & 0,7 & 1,27 & 0,3 & 0,00 & & 22,48 & 6,52 \\
\hline 29/mai & 1,76 & 0,7 & 0,99 & 0,3 & 0,00 & & 21,50 & 7,50 \\
\hline 30/mai & 3,12 & 0,7 & 1,75 & 0,3 & 0,00 & & 19,75 & 9,25 \\
\hline 31/mai & 2,85 & 0,7 & 1,6 & 0,3 & 0,00 & & 18,15 & 10,85 \\
\hline 1/jun & 2,94 & 0,7 & 1,65 & 0,3 & 0,00 & 9 & 25,51 & 3,49 \\
\hline 2/jun & 3,57 & 0,7 & 2 & 0,3 & 0,00 & & 23,51 & 5,49 \\
\hline 3/jun & 2,98 & 0,7 & 1,67 & 0,3 & 0,00 & & 21,84 & 7,16 \\
\hline 4/jun & 3,60 & 0,7 & 2,02 & 0,3 & 0,00 & & 19,82 & 9,18 \\
\hline 5/jun & 1,36 & 0,7 & 0,76 & 0,3 & 0,00 & & 19,06 & 9,94 \\
\hline 6/jun & 3,26 & 0,7 & 1,83 & 0,3 & 0,00 & 9 & 26,24 & 2,76 \\
\hline 7/jun & 3,50 & 0,7 & 1,96 & 0,3 & 0,00 & & 24,28 & 4,72 \\
\hline 8/jun & 1,80 & 0,7 & 1,01 & 0,3 & 0,00 & 9 & 29,00 & 0,00 \\
\hline 9/jun & 5,06 & 0,7 & 2,83 & 0,3 & 0,00 & & 26,17 & 2,83 \\
\hline 10/jun & 3,97 & 0,7 & 2,22 & 0,3 & 0,00 & & 23,94 & 5,06 \\
\hline $11 /$ jun & 3,27 & 0,7 & 1,83 & 0,3 & 0,00 & & 22,11 & 6,89 \\
\hline 12/jun & 2,64 & 0,7 & 1,48 & 0,3 & 0,00 & & 20,63 & 8,37 \\
\hline 13/jun & 2,44 & 0,7 & 1,37 & 0,3 & 0,00 & 9 & 28,27 & 0,73 \\
\hline 14/jun & 3,22 & 0,7 & 1,8 & 0,3 & 0,00 & & 26,46 & 2,54 \\
\hline 15/jun & 3,00 & 0,7 & 1,68 & 0,3 & 0,00 & & 24,78 & 4,22 \\
\hline 16/jun & 3,82 & 0,7 & 2,14 & 0,3 & 0,00 & & 22,64 & 6,36 \\
\hline 17/jun & 0,49 & 0,7 & 0,27 & 0,3 & 2,70 & & 25,07 & 3,93 \\
\hline
\end{tabular}




\begin{tabular}{|c|c|c|c|c|c|c|c|c|}
\hline DATA & ETo & $\mathrm{Kc}$ & ETPC & $\begin{array}{l}\text { Profundidade } \\
\text { de Raizes }(m)\end{array}$ & $\begin{array}{l}\text { Chuva } \\
\text { (mm) }\end{array}$ & $\begin{array}{c}\text { Irrigação } \\
\text { (mm) }\end{array}$ & $\begin{array}{l}\text { Saldo } \\
(\mathrm{mm})\end{array}$ & $\begin{array}{l}\text { Deficit } \\
(\mathrm{mm})\end{array}$ \\
\hline 18/jun & 0,99 & 0,7 & 0,55 & 0,3 & 10,20 & & 29,00 & 0,00 \\
\hline 19/jun & 2,40 & 1,1 & 2,11 & 0,3 & 0,00 & & 26,89 & 2,11 \\
\hline 20/jun & 3,00 & 1,1 & 2,64 & 0,3 & 0,00 & & 24,25 & 4,75 \\
\hline 21/jun & 1,64 & 1,1 & 1,44 & 0,3 & 0,00 & 9 & 29,00 & 0,00 \\
\hline $22 /$ jun & 2,12 & 1,1 & 1,87 & 0,3 & 0,00 & 9 & 29,00 & 0,00 \\
\hline 23/jun & 3,16 & 1,1 & 2,78 & 0,3 & 0,00 & & 26,22 & 2,78 \\
\hline 24/jun & 3,99 & 1,1 & 3,51 & 0,3 & 0,00 & & 22,71 & 6,29 \\
\hline 25 /jun & 2,17 & 1,1 & 1,91 & 0,3 & 10,60 & & 29,00 & 0,00 \\
\hline 26/jun & 1,82 & 1,1 & 1,6 & 0,3 & 0,00 & & 27,40 & 1,60 \\
\hline 27/jun & 2,86 & 1,1 & 2,52 & 0,3 & 0,00 & & 24,88 & 4,12 \\
\hline 28/jun & 2,98 & 1,1 & 2,62 & 0,3 & 0,00 & 9 & 29,00 & 0,00 \\
\hline 29/jun & 1,01 & 1,1 & 0,89 & 0,3 & 0,00 & & 28,11 & 0,89 \\
\hline 30/jun & 3,97 & 1,1 & 3,49 & 0,3 & 0,00 & & 24,62 & 4,38 \\
\hline 1/jul & 3,06 & 1,1 & 2,69 & 0,3 & 0,00 & & 21,92 & 7,08 \\
\hline 2/jul & 2,86 & 1,1 & 2,52 & 0,3 & 0,00 & & 19,41 & 9,59 \\
\hline 3/jul & 3,40 & 1,1 & 2,99 & 0,3 & 0,00 & & 16,42 & 12,58 \\
\hline 4/jul & 3,54 & 1,1 & 3,12 & 0,3 & 0,00 & & 13,30 & 15,70 \\
\hline $5 / \mathrm{jul}$ & 3,33 & 1,1 & 2,93 & 0,3 & 0,00 & & 10,37 & 18,63 \\
\hline 6/jul & 3,61 & 1,1 & 3,18 & 0,3 & 0,00 & & 7,19 & 21,81 \\
\hline 7/jul & 4,30 & 1,1 & 3,78 & 0,3 & 0,50 & 18 & 21,91 & 7,09 \\
\hline 8/jul & 0,24 & 1,1 & 0,21 & 0,3 & 7,20 & & 28,90 & 0,10 \\
\hline 9/jul & 2,94 & 1,1 & 2,59 & 0,3 & 44,10 & & 29,00 & 0,00 \\
\hline 10/jul & 0,89 & 1,1 & 0,78 & 0,3 & 1,00 & & 29,00 & 0,00 \\
\hline $11 / j u l$ & 2,37 & 1,1 & 2,09 & 0,3 & 0,00 & & 26,91 & 2,09 \\
\hline $12 / j u l$ & 2,97 & 1,1 & 2,61 & 0,3 & 0,00 & & 24,30 & 4,70 \\
\hline $13 / j u l$ & 1,75 & 1,1 & 1,54 & 0,3 & 0,00 & 9 & 29,00 & 0,00 \\
\hline 14/jul & 4,17 & 1,1 & 3,67 & 0,3 & 0,00 & & 25,33 & 3,67 \\
\hline $15 / j u l$ & 2,11 & 1,1 & 1,86 & 0,3 & 0,00 & & 23,47 & 5,53 \\
\hline 16/jul & 2,72 & 1,1 & 2,39 & 0,3 & 0,00 & & 21,08 & 7,92 \\
\hline 17/jul & 3,08 & 1,1 & 2,71 & 0,3 & 0,00 & 9 & 27,37 & 1,63 \\
\hline 18/jul & 3,52 & 1,1 & 3,1 & 0,3 & 0,00 & & 24,27 & 4,73 \\
\hline 19/jul & 4,28 & 1,1 & 3,77 & 0,3 & 0,00 & & 20,51 & 8,49 \\
\hline $20 / j u l$ & 1,78 & 1,1 & 1,57 & 0,3 & 0,00 & & 18,94 & 10,06 \\
\hline 21/jul & 1,72 & 1,1 & 1,51 & 0,3 & 5,90 & 9 & 29,00 & 0,00 \\
\hline $22 / j u l$ & 1,28 & 1,1 & 1,13 & 0,3 & 0,00 & & 27,87 & 1,13 \\
\hline 23/jul & 2,28 & 1,1 & 2,01 & 0,3 & 0,00 & & 25,87 & 3,13 \\
\hline 24/jul & 3,32 & 1,1 & 2,92 & 0,3 & 0,00 & & 22,95 & 6,05 \\
\hline 25/jul & 3,96 & 1,1 & 3,48 & 0,3 & 0,00 & & 19,46 & 9,54 \\
\hline 26/jul & 3,72 & 1,1 & 3,27 & 0,3 & 0,00 & 9 & 25,19 & 3,81 \\
\hline 27/jul & 3,39 & 1,1 & 2,98 & 0,3 & 0,00 & & 22,20 & 6,80 \\
\hline 28/jul & 6,13 & 1,1 & 5,39 & 0,3 & 0,00 & & 16,81 & 12,19 \\
\hline 29/jul & 4,60 & 1,1 & 4,05 & 0,3 & 0,00 & & 12,76 & 16,24 \\
\hline 30/jul & 2,40 & 1,1 & 2,11 & 0,3 & 0,00 & & 10,65 & 18,35 \\
\hline 31/jul & 3,94 & 1,1 & 3,47 & 0,3 & 0,00 & 9 & 16,18 & 12,82 \\
\hline 1/ago & 5,10 & 1,1 & 4,49 & 0,3 & 0,00 & 9 & 20,69 & 8,31 \\
\hline 2/ago & 4,66 & 1,1 & 4,1 & 0,3 & 0,00 & & 16,59 & 12,41 \\
\hline 3/ago & 3,14 & 1,1 & 2,76 & 0,3 & 0,00 & 9 & 22,83 & 6,17 \\
\hline 4/ago & 5,08 & 1,1 & 4,47 & 0,3 & 0,90 & & 19,26 & 9,74 \\
\hline 5/ago & 1,92 & 1,1 & 1,69 & 0,3 & 0,30 & & 17,87 & 11,13 \\
\hline 6/ago & 2,76 & 1,1 & 2,43 & 0,3 & 0,00 & & 15,44 & 13,56 \\
\hline 7/ago & 4,04 & 0,9 & 2,91 & 0,3 & 0,00 & 9 & 21,53 & 7,47 \\
\hline 8/ago & 4,16 & 0,9 & 3 & 0,3 & 0,00 & & 18,54 & 10,46 \\
\hline 9/ago & 5,22 & 0,9 & 3,76 & 0,3 & 0,00 & 9 & 23,78 & 5,22 \\
\hline 10/ago & 4,49 & 0,9 & 3,23 & 0,3 & 0,00 & & 20,55 & 8,45 \\
\hline 11/ago & 5,02 & 0,9 & 3,61 & 0,3 & 0,00 & & 16,93 & 12,07 \\
\hline 12/ago & 5,14 & 0,9 & 3,7 & 0,3 & 0,00 & & 13,23 & 15,77 \\
\hline 13/ago & 4,56 & 0,9 & 3,28 & 0,3 & 0,00 & & 9,95 & 19,05 \\
\hline 14/ago & 5,98 & 0,9 & 4,31 & 0,3 & 0,00 & 9 & 14,64 & 14,36 \\
\hline
\end{tabular}




\begin{tabular}{|c|c|c|c|c|c|c|c|c|}
\hline DATA & ETo & $\mathrm{Kc}$ & ETPc & $\begin{array}{l}\text { Profundidade } \\
\text { de Raizes }(m)\end{array}$ & $\begin{array}{l}\text { Chuva } \\
(\mathrm{mm})\end{array}$ & $\begin{array}{c}\text { Irrigação } \\
\text { (mm) }\end{array}$ & $\begin{array}{l}\text { Saldo } \\
(\mathrm{mm})\end{array}$ & $\begin{array}{c}\text { Deficit } \\
\text { (mm) }\end{array}$ \\
\hline 15/ago & 6,46 & 0,9 & 4,65 & 0,3 & 0,00 & & 9,99 & 19,01 \\
\hline 16/ago & 3,41 & 0,9 & 2,46 & 0,3 & 0,00 & 9 & 16,54 & 12,46 \\
\hline 17/ago & 4,42 & 0,9 & 3,18 & 0,3 & 0,00 & & 13,35 & 15,65 \\
\hline 18/ago & 5,46 & 0,9 & 3,93 & 0,3 & 0,00 & 9 & 18,42 & 10,58 \\
\hline 19/ago & 5,78 & 0,9 & 4,16 & 0,3 & 0,00 & & 14,26 & 14,74 \\
\hline 20/ago & 4,48 & 0,9 & 3,23 & 0,3 & 0,00 & & 11,04 & 17,96 \\
\hline 21/ago & 4,16 & 0,9 & 3 & 0,3 & 0,00 & 9 & 17,04 & 11,96 \\
\hline 22/ago & 3,80 & 0,9 & 2,74 & 0,3 & 0,00 & 18 & 29,00 & 0,00 \\
\hline 23/ago & 5,60 & 0,9 & 4,03 & 0,3 & 0,00 & 9 & 29,00 & 0,00 \\
\hline 24/ago & 5,88 & 0,9 & 4,23 & 0,3 & 0,00 & & 24,77 & 4,23 \\
\hline 25/ago & 5,90 & 0,9 & 4,25 & 0,3 & 0,00 & 9 & 29,00 & 0,00 \\
\hline 26/ago & 5,54 & 0,9 & 3,99 & 0,3 & 0,00 & & 25,01 & 3,99 \\
\hline 27/ago & 6,08 & 0,9 & 4,38 & 0,3 & 0,00 & & 20,63 & 8,37 \\
\hline 28/ago & 3,61 & 0,9 & 2,6 & 0,3 & 0,00 & 9 & 27,03 & 1,97 \\
\hline 29/ago & 6,11 & 0,9 & 4,4 & 0,3 & 0,00 & & 22,64 & 6,36 \\
\hline 30/ago & 6,90 & 0,9 & 4,97 & 0,3 & 0,00 & & 17,67 & 11,33 \\
\hline 31/ago & 5,60 & 0,9 & 4,03 & 0,3 & 0,00 & & 13,64 & 15,36 \\
\hline 1/set & 7,76 & 0,9 & 5,59 & 0,3 & 0,00 & & 8,05 & 20,95 \\
\hline 2/set & 6,58 & 0,9 & 4,74 & 0,3 & 0,00 & & 3,31 & 25,69 \\
\hline 3/set & 5,66 & 0,9 & 4,08 & 0,3 & 0,00 & & 0,00 & 29,00 \\
\hline 4/set & 5,76 & 0,9 & 4,15 & 0,3 & 0,00 & & 0,00 & 29,00 \\
\hline $5 /$ set & 6,12 & 0,9 & 4,41 & 0,3 & 0,00 & & 0,00 & 29,00 \\
\hline $6 /$ set & 6,06 & 0,9 & 4,36 & 0,3 & 0,00 & & 0,00 & 29,00 \\
\hline $7 / \mathrm{set}$ & 5,78 & 0,9 & 4,16 & 0,3 & 0,00 & & 0,00 & 29,00 \\
\hline 8/set & 5,98 & 0,9 & 4,31 & 0,3 & 0,00 & & 0,00 & 29,00 \\
\hline 9/set & 6,28 & 0,9 & 4,52 & 0,3 & 0,00 & & 0,00 & 29,00 \\
\hline $10 /$ set & 6,68 & 0,9 & 4,81 & 0,3 & 0,00 & & 0,00 & 29,00 \\
\hline $11 /$ set & 7,26 & 0,9 & 5,23 & 0,3 & 0,00 & & 0,00 & 29,00 \\
\hline $12 /$ set & 6,07 & 0,9 & 4,37 & 0,3 & 0,00 & & 0,00 & 29,00 \\
\hline $13 /$ set & 3,97 & 0,9 & 2,86 & 0,3 & 0,00 & & 0,00 & 29,00 \\
\hline 14/set & 5,86 & 1,9 & 8,91 & 1,3 & 0,00 & & 0,00 & 29,00 \\
\hline $15 /$ set & 6,31 & 2,9 & 14,6 & 2,3 & 0,00 & & 0,00 & 29,00 \\
\hline 16/set & 7,12 & 3,9 & 22,2 & 3,3 & 0,00 & & 0,00 & 29,00 \\
\hline $17 /$ set & 1,94 & 4,9 & 7,6 & 4,3 & 3,50 & & 0,00 & 29,00 \\
\hline $18 /$ set & 5,54 & 5,9 & 26,1 & 5,3 & 3,90 & & 0,00 & 29,00 \\
\hline $19 /$ set & 6,56 & 6,9 & 36,2 & 6,3 & 5,50 & & 0,00 & 29,00 \\
\hline 20/set & 2,54 & 7,9 & 16,1 & 7,3 & 0,60 & & 0,00 & 29,00 \\
\hline $21 /$ set & 3,50 & 8,9 & 24,9 & 8,3 & 0,00 & & 0,00 & 29.00 \\
\hline
\end{tabular}


APENDICE 5 - Dados e resultados dos testes de uniformidade; velocidade do vento durante os testes. 
PARCELA I - $18 \times 18$

teste de aspersores no campo

4 aspersores a $18 \times 18 \mathrm{~m}$

24/05/95 18-19:00h

altura do aspersor $=200 \mathrm{~cm}$

cultura: $\quad 52 \mathrm{~cm}$

coletores: $\quad 30 \mathrm{~cm}$

valores em mililitros:

teste de aspersores no campo

4 aspersores a $18 \times 18 \mathrm{~m}$

$30 / 05 / 95$

18:30-19:10h

altura do aspersor $=200 \mathrm{~cm}$

cultura: $\quad 63 \mathrm{~cm}$

coletores: $\quad 30 \mathrm{~cm}$

valores em mililitros:

teste de aspersores no campo

4 aspersores a $18 \times 18 \mathrm{~m}$

01/06/95 6:15-6:45h

altura do aspersor $=200 \mathrm{~cm}$

cultura: $\quad 65 \mathrm{~cm}$

coletores: $\quad 30 \mathrm{~cm}$

valores em mililitros

teste de aspersores no campo

4 aspersores a $18 \times 18 \mathrm{~m}$

06/06/95 18:10-19:00h

altura do aspersor $=200 \mathrm{~cm}$

cultura: $\quad 69 \mathrm{~cm}$

coletores: $\quad 30 \mathrm{~cm}$

valores em mililitros

teste de aspersores no campo

4 aspersores a $18 \times 18 \mathrm{~m}$

07/06/95 6:05-7:05

altura do aspersor $=200 \mathrm{~cm}$

cultura: $\quad 69 \mathrm{~cm}$

coletores: $\quad 30 \mathrm{~cm}$

valores em mililitros

teste de aspersores no campo

4 aspersores a $18 \times 18 \mathrm{~m}$

$21 / 06 / 95$

$16: 40-17: 40$

altura do aspersor $=200 \mathrm{~cm}$

cultura: $\quad 126 \mathrm{~cm}$

coletores: $\quad 30 \mathrm{~cm}$

valores em mililitros

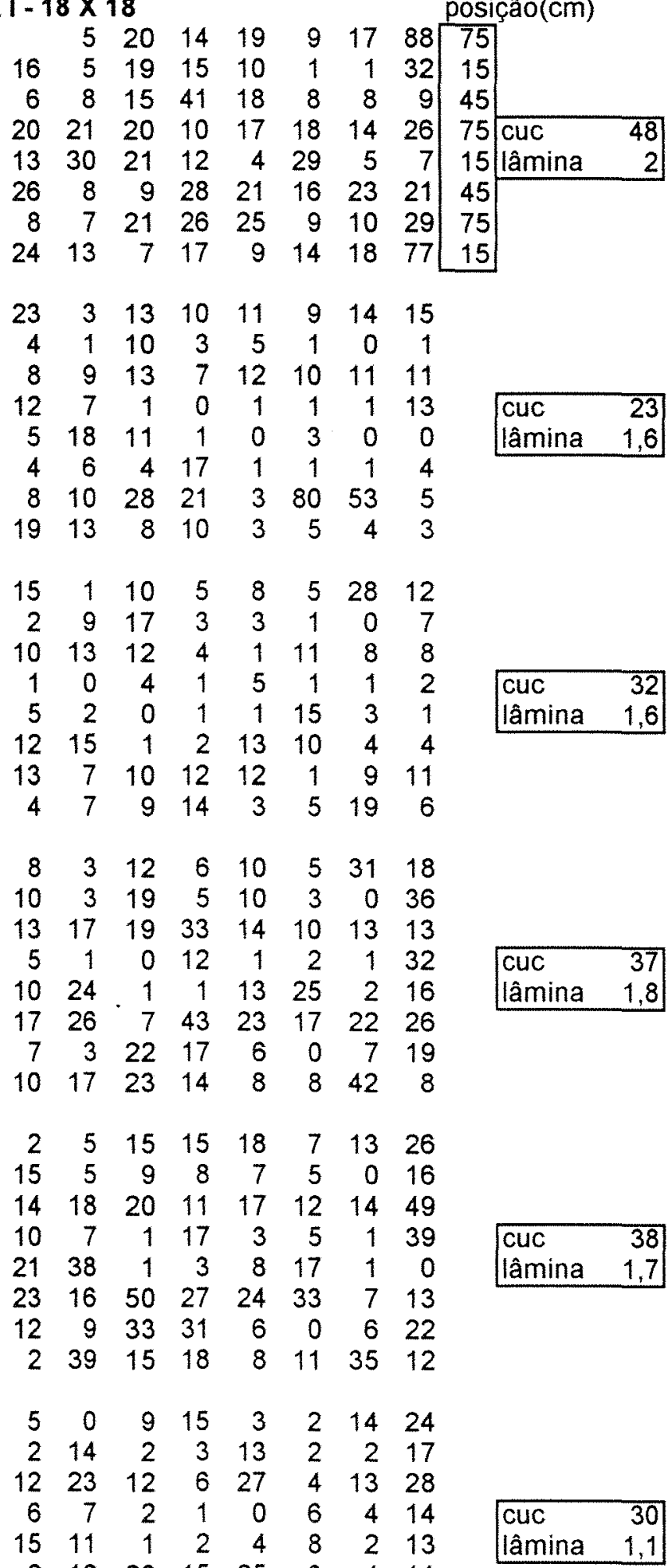

$\begin{array}{llllllll}2 & 12 & 23 & 15 & 25 & 3 & 4 & 11\end{array}$

$\begin{array}{llllllll}3 & 13 & 18 & 12 & 35 & 1 & 7 & 14\end{array}$

$\begin{array}{llllllll}0 & 42 & 7 & 16 & 0 & 7 & 9 & 8\end{array}$ 
teste de aspersores no campo 4 aspersores a $18 \times 18 \mathrm{~m}$ 22/06/95

18:45-19:45

altura do aspersor $=200 \mathrm{~cm}$

cultura: $\quad 126 \mathrm{~cm}$

coletores: $\quad 30 \mathrm{~cm}$

valores em mililitros

teste de aspersores no campo 4 aspersores a $18 \times 18 \mathrm{~m}$ 28/06/95 $17 ; 55-18 ; 55$

altura do aspersor $=200 \mathrm{~cm}$

cultura: $\quad 143 \mathrm{~cm}$

coletores: $\quad 30 \mathrm{~cm}$

valores em mililitros

teste de aspersores no campo 4 aspersores a $18 \times 18 \mathrm{~m}$ $17 / 07 / 95$ 18:50-19:50

altura do aspersor $=200 \mathrm{~cm}$

cultura: $\quad 172 \mathrm{~cm}$

coletores: $\quad 30 \mathrm{~cm}$

valores em mililitros

teste de aspersores no campo 4 aspersores a $18 \times 18 \mathrm{~m}$ $21 / 07 / 95$ 8:45-9:30

altura do aspersor $=200 \mathrm{~cm}$ cultura: $\quad 172 \mathrm{~cm}$ coletores: $\quad 30 \mathrm{~cm}$

valores em mililitros

teste de aspersores no campo 4 aspersores a $18 \times 18 \mathrm{~m}$ 26/07/95 $17: 15-18: 15$ altura do aspersor $=200 \mathrm{~cm}$

cultura: $\quad 172 \mathrm{~cm}$

coletores: $\quad 30 \mathrm{~cm}$

valores em mililitros

teste de aspersores no campo 4 aspersores a $18 \times 18 \mathrm{~m}$ cultura: $\quad 172 \mathrm{~cm}$ coletores: $\quad 30 \mathrm{~cm}$ 01/08/95 17:15-18:15 altura do aspersor $=200 \mathrm{~cm}$

valores em mililitros

\begin{tabular}{rrrrrrrrlll}
1 & 1 & 5 & 14 & 5 & 1 & 5 & 30 & & \\
11 & 7 & 4 & 5 & 6 & 3 & 0 & 38 & & \\
13 & 19 & 11 & 13 & 15 & 4 & 10 & 26 & & \\
7 & 6 & 2 & 1 & 0 & 3 & 25 & 16 & Cuc & 28 \\
18 & 14 & 9 & 6 & 14 & 9 & 3 & 5 & lâmina & 1,3 \\
6 & 6 & 4 & 8 & 34 & 5 & 50 & 17 & & \\
2 & 11 & 13 & 26 & 23 & 1 & 4 & 11 & & \\
5 & 41 & 5 & 13 & 2 & 9 & 5 & 38 & & \\
& & & & & & & & & \\
1 & 0 & 3 & 2 & 7 & 4 & 5 & 22 & & \\
9 & 10 & 19 & 19 & 7 & 2 & 1 & 19 & & \\
5 & 9 & 13 & 2 & 49 & 1 & 41 & 6 & & \\
8 & 7 & 4 & 1 & 1 & 1 & 2 & 9 & Cuc & 21 \\
14 & 15 & 6 & 16 & 12 & 5 & 3 & 5 & lâmina & 1,2 \\
3 & 15 & 13 & 8 & 54 & 2 & 54 & 11 & & \\
6 & 9 & 9 & 13 & 13 & 0 & 0 & 30 & & \\
0 & 0 & 2 & 7 & 5 & 9 & 3 & 14 & & \\
& & & & & & & & & \\
0 & 0 & 0 & 4 & 2 & 0 & 9 & 47 & & \\
6 & 24 & 26 & 28 & 3 & 3 & 0 & 18 & & \\
12 & 13 & 22 & 4 & 7 & 15 & 26 & 8 & & \\
5 & 5 & 0 & 1 & 0 & 0 & 1 & 0 & Cuc & \\
9 & 4 & 1 & 10 & 6 & 23 & 2 & 1 & lâmina & \\
2 & 2 & 3 & 3 & 3 & 1 & 53 & 14 & & 15 \\
\hline
\end{tabular}
lâmina 1,1

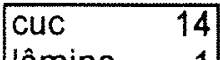

lâmina 1

cuc

lâmina $\quad 1,2$ 
teste de aspersores no campo 4 aspersores a $18 \times 18 \mathrm{~m}$ 03/08/95 17:20-18:20 altura do aspersor $=200 \mathrm{~cm}$ cultura: $\quad 172 \mathrm{~cm}$ coletores: $\quad 30 \mathrm{~cm}$

valores em mililitros

teste de aspersores no campo 4 aspersores a $18 \times 18 \mathrm{~m}$ $07 / 08 / 95$ $17: 40-18: 40$ altura do aspersor $=200 \mathrm{~cm}$ cultura: $\quad 172 \mathrm{~cm}$ coletores: $\quad 30 \mathrm{~cm}$

valores em mililitros

teste de aspersores no campo 4 aspersores a $18 \times 18 \mathrm{~m}$ 09/08/95 $17: 20-18: 20$ altura do aspersor $=200 \mathrm{~cm}$ cultura: $\quad 172 \mathrm{~cm}$ coletores: $\quad 30 \mathrm{~cm}$

valores em mililitros

teste de aspersores no campo 4 aspersores a $18 \times 18 \mathrm{~m}$ $14 / 08 / 95$ $17: 40-18: 40$ altura do aspersor $=200 \mathrm{~cm}$ cultura: $\quad 172 \mathrm{~cm}$ coletores: $\quad 30 \mathrm{~cm}$

valores em mililitros

teste de aspersores no campo 4 aspersores a $18 \times 18 \mathrm{~m}$ $21 / 08 / 95 \quad 17: 30-18: 30$ altura do aspersor $=200 \mathrm{~cm}$ cultura: $\quad 172 \mathrm{~cm}$ coletores: $\quad 30 \mathrm{~cm}$

valores em mililitros

teste de aspersores no campo 4 aspersores a $18 \times 18 \mathrm{~m}$ 23/08/95 $17: 30-18: 30$ altura do aspersor $=200 \mathrm{~cm}$ cultura: $\quad 172 \mathrm{~cm}$ coletores: $\quad 30 \mathrm{~cm}$

valores em mililitros

$\begin{array}{rrrrrrrrlll}0 & 0 & 0 & 0 & 5 & 0 & 0 & 1 & & \\ 3 & 24 & 8 & 15 & 14 & 13 & 5 & 31 & & \\ 9 & 6 & 28 & 14 & 27 & 14 & 58 & 14 & & \\ 0 & 0 & 0 & 0 & 2 & 4 & 2 & 0 & \text { Cuc } & -2 \\ 9 & 5 & 2 & 2 & 0 & 1 & 2 & 0 & \text { lâmina } & 1,1 \\ 10 & 40 & 29 & 0 & 0 & 5 & 81 & 13 & & \\ 3 & 2 & 5 & 20 & 11 & 0 & 0 & 4 & & \\ 0 & 5 & 0 & 3 & 12 & 17 & 12 & 4 & & \\ & & & & & & & & & \\ 4 & 6 & 0 & 1 & 3 & 9 & 0 & 19 & & \\ 2 & 17 & 13 & 24 & 13 & 16 & 5 & 18 & & \\ 45 & 1 & 6 & 36 & 1 & 21 & 57 & 21 & & \\ 1 & 2 & 1 & 2 & 0 & 3 & 9 & 1 & \text { Cuc } & 16 \\ 5 & 4 & 1 & 1 & 10 & 5 & 15 & 20 & \text { lâmina } & 1,3 \\ 11 & 30 & 23 & 1 & 10 & 11 & 46 & 5 & & \\ 3 & 3 & 4 & 29 & 11 & 1 & 1 & 19 & & \\ 15 & 1 & 0 & 5 & 16 & 30 & 8 & 11 & & \\ & & & & & & & & & \\ 0 & 0 & 0 & 0 & 1 & 0 & 0 & 11 & & \\ 2 & 22 & 16 & 15 & 11 & 8 & 1 & 48 & & \\ 13 & 0 & 5 & 25 & 0 & 1 & 56 & 6 & & \\ 2 & 0 & 0 & 1 & 1 & 1 & 1 & 0 & \text { Cuc } & -1 \\ 12 & 13 & 27 & 1 & 1 & 1 & 1 & 0 & \text { lâmina } & 1,1 \\ 0 & 72 & 4 & 2 & 0 & 7 & 44 & 13 & & \end{array}$

$\begin{array}{llllllll}9 & 72 & 4 & 2 & 0 & 7 & 44 & 13\end{array}$

$\begin{array}{llllllll}4 & 3 & 8 & 22 & 9 & 0 & 8 & 24\end{array}$

$\begin{array}{llllllll}0 & 5 & 5 & 5 & 10 & 18 & 15 & 20\end{array}$

$\begin{array}{rrrrrrrr}0 & 0 & 0 & 0 & 1 & 0 & 0 & 6 \\ 34 & 28 & 10 & 20 & 7 & 17 & 1 & 41 \\ 6 & 0 & 34 & 37 & 9 & 1 & 38 & 10 \\ 1 & 1 & 0 & 0 & 1 & 0 & 0 & 0 \\ 6 & 6 & 4 & 4 & 3 & 2 & 0 & 0 \\ 11 & 8 & 6 & 0 & 3 & 1 & 55 & 9 \\ 0 & 1 & 42 & 22 & 4 & 0 & 7 & 22 \\ 1 & 6 & 4 & 2 & 6 & 17 & 11 & 7\end{array}$

\begin{tabular}{|lr|}
\hline Cuc & -4 \\
lâmina & 1 \\
\hline
\end{tabular}

$\begin{array}{llllllll}7 & 0 & 1 & 2 & 8 & 1 & 2 & 14\end{array}$

$\begin{array}{llllllll}0 & 22 & 15 & 10 & 3 & 2 & 3 & 20\end{array}$

$\begin{array}{llllllll}20 & 1 & 9 & 14 & 0 & 3 & 39 & 78\end{array}$

$\begin{array}{llllllll}2 & 11 & 1 & 8 & 1 & 3 & 0 & 0\end{array}$

$\begin{array}{llllllll}18 & 21 & 4 & 1 & 6 & 1 & 10 & 3\end{array}$

$\begin{array}{llllllll}5 & 34 & 24 & 0 & 9 & 13 & 41 & 11\end{array}$

$\begin{array}{llllllll}5 & 23 & 16 & 67 & 11 & 0 & 2 & 10\end{array}$

$\begin{array}{llllllll}5 & 8 & 7 & 5 & 4 & 10 & 12 & 48\end{array}$

\begin{tabular}{|lr|}
\hline Cuc & 13 \\
lâmina & 1,3 \\
\hline
\end{tabular}

$\begin{array}{rrrrrrrr}45 & 0 & 0 & 1 & 1 & 0 & 0 & 26 \\ 1 & 16 & 11 & 9 & 12 & 0 & 1 & 20 \\ 11 & 0 & 6 & 31 & 0 & 0 & 15 & 53 \\ 5 & 4 & 1 & 3 & 0 & 0 & 0 & 0 \\ 29 & 33 & 1 & 2 & 6 & 1 & 25 & 0 \\ 0 & 6 & 92 & 1 & 7 & 9 & 44 & 11 \\ 1 & 5 & 11 & 61 & 5 & 0 & 0 & 4 \\ 7 & 6 & 1 & 5 & 1 & 7 & 7 & 29\end{array}$

\begin{tabular}{|lr|}
\hline Cuc & -8 \\
lâmina & 1,2 \\
\hline
\end{tabular} 
teste de aspersores no campo

4 aspersores a $18 \times 18 \mathrm{~m}$

29/08/95 17:15-18:15

altura do aspersor $=200 \mathrm{~cm}$

cultura: $\quad 172 \mathrm{~cm}$

coletores: $\quad 30 \mathrm{~cm}$

valores em mililitros

teste de aspersores no campo

4 aspersores a $18 \times 18 \mathrm{~m}$

$30 / 08 / 95$

17:15-18:15

altura do aspersor $=200 \mathrm{~cm}$

cultura: $\quad 172 \mathrm{~cm}$

coletores: $\quad 30 \mathrm{~cm}$

valores em mililitros

teste de aspersores no campo

4 aspersores a $18 \times 18 \mathrm{~m}$

cultura: $\quad 172 \mathrm{~cm}$

coletores: $\quad 30 \mathrm{~cm}$

13/09/95 17:20-18:20

altura do aspersor $=200 \mathrm{~cm}$

valores em mililitros

teste de aspersores no campo

4 aspersores a $18 \times 18 \mathrm{~m}$

06/10/95

17:00-18:00

altura do aspersor $=200 \mathrm{~cm}$

cultura:

$\mathrm{cm}$

coletores: $\quad 30 \mathrm{~cm}$

valores em mililitros

teste de aspersores no campo

4 aspersores a $18 \times 18 \mathrm{~m}$

09/10/95

$8: 15-9: 15 h$

altura do aspersor $=200 \mathrm{~cm}$

cultura:

$\mathrm{cm}$

coletores: $\quad 30 \mathrm{~cm}$

valores em mililitros

teste de aspersores no campo

4 aspersores a $18 \times 18 \mathrm{~m}$

$10 / 10 / 95$

$7: 50-8: 50 \mathrm{~h}$

altura do aspersor $=200 \mathrm{~cm}$

cultura:

$\mathrm{cm}$

coletores: $\quad 30 \mathrm{~cm}$

valores em mililitros $\begin{array}{llllllll}25 & 0 & 1 & 3 & 7 & 13 & 1 & 3\end{array}$

$\begin{array}{llllllll}7 & 16 & 4 & 8 & 37 & 1 & 1 & 5\end{array}$

$\begin{array}{llllllll}17 & 1 & 15 & 6 & 1 & 5 & 24 & 33\end{array}$

$\begin{array}{rrrrrrrr}12 & 7 & 12 & 7 & 0 & 9 & 14 & 0\end{array}$

$\begin{array}{llllllll}38 & 7 & 0 & 7 & 6 & 0 & 6 & 1\end{array}$

$\begin{array}{llllllll}4 & 3 & 5 & 2 & 6 & 8 & 44 & 1\end{array}$

$\begin{array}{rrrrrrrr}0 & 1 & 5 & 24 & 24 & 20 & 1 & 1 \\ 11 & 4 & 0 & 5 & 1 & 5 & 4 & 40\end{array}$

$\begin{array}{llllllll}41 & 0 & 11 & 12 & 7 & 17 & 4 & 7\end{array}$

$\begin{array}{llllllll}2 & 10 & 5 & 34 & 13 & 0 & 5 & 3\end{array}$

$\begin{array}{rrrrrrrr}11 & 9 & 6 & 5 & 0 & 12 & 10 & 30\end{array}$

$\begin{array}{llllllll}9 & 3 & 7 & 3 & 0 & 6 & 9 & 0\end{array}$

$\begin{array}{llllllll}18 & 9 & 0 & 0 & 6 & 0 & 4 & 0\end{array}$

$\begin{array}{llllllll}0 & 0 & 24 & 1 & 1 & 21 & 23 & 1\end{array}$

$\begin{array}{llllllll}0 & 3 & 11 & 22 & 13 & 25 & 1 & 39\end{array}$

$\begin{array}{llllllll}9 & 9 & 0 & 1 & 0 & 5 & 7 & 78\end{array}$

$\begin{array}{llllllll}19 & 9 & 17 & 38 & 20 & 5 & 3 & 42\end{array}$

$\begin{array}{llllllll}0 & 8 & 16 & 2 & 10 & 16 & 11 & 9\end{array}$

$\begin{array}{llllllll}12 & 15 & 9 & 3 & 12 & 15 & 21 & 20\end{array}$

$\begin{array}{llllllll}3 & 6 & 5 & 2 & 1 & 5 & 2 & 6\end{array}$

$\begin{array}{rrrrrrrr}13 & 30 & 7 & 1 & 12 & 1 & 14 & 1\end{array}$

$\begin{array}{llllllll}1 & 1 & 11 & 5 & 5 & 2 & 2 & 2\end{array}$

$\begin{array}{llllllll}14 & 12 & 22 & 75 & 11 & 10 & 8 & 17\end{array}$

$\begin{array}{llllllll}14 & 8 & 5 & 9 & 1 & 5 & 16 & 46\end{array}$

$\begin{array}{llllllll}80 & 18 & 11 & 23 & 27 & 12 & 15 & 54\end{array}$

$\begin{array}{llllllll}13 & 8 & 13 & 24 & 25 & 12 & 7 & 14\end{array}$

$\begin{array}{llllllll}11 & 11 & 14 & 23 & 19 & 13 & 15 & 15\end{array}$

$\begin{array}{llllllll}28 & 24 & 22 & 20 & 16 & 22 & 28 & 27\end{array}$

$\begin{array}{llllllll}26 & 23 & 17 & 15 & 19 & 24 & 25 & 25\end{array}$

$\begin{array}{llllllll}13 & 10 & 13 & 20 & 24 & 14 & 13 & 13\end{array}$

$\begin{array}{llllllll}12 & 6 & 14 & 26 & 30 & 15 & 9 & 16\end{array}$

$\begin{array}{llllllll}47 & 13 & 16 & 30 & 28 & 12 & 15 & 59\end{array}$

$\begin{array}{llllllll}42 & 37 & 11 & 21 & 27 & 18 & 10 & 33\end{array}$

$\begin{array}{llllllll}13 & 13 & 14 & 16 & 19 & 13 & 10 & 11\end{array}$

$\begin{array}{llllllll}17 & 18 & 16 & 14 & 8 & 7 & 13 & 17\end{array}$

$\begin{array}{llllllll}28 & 24 & 17 & 8 & 1 & 7 & 16 & 22\end{array}$

$\begin{array}{llllllll}23 & 18 & 17 & 14 & 7 & 10 & 21 & 23\end{array}$

$\begin{array}{llllllll}13 & 11 & 15 & 17 & 24 & 17 & 17 & 16\end{array}$

$\begin{array}{llllllll}22 & 13 & 12 & 23 & 32 & 23 & 14 & 32\end{array}$

$\begin{array}{llllllll}37 & 31 & 15 & 26 & 31 & 23 & 14 & 48\end{array}$

$\begin{array}{llllllll}46 & 60 & 12 & 16 & 31 & 24 & 11 & 34\end{array}$

$\begin{array}{llllllll}19 & 15 & 14 & 19 & 25 & 21 & 13 & 16\end{array}$

$\begin{array}{llllllll}17 & 20 & 20 & 18 & 10 & 11 & 17 & 19\end{array}$

$\begin{array}{rrrrrrrr}28 & 27 & 23 & 9 & 1 & 4 & 14 & 25\end{array}$

$\begin{array}{llllllll}25 & 21 & 17 & 13 & 5 & 5 & 20 & 16\end{array}$

$\begin{array}{llllllll}18 & 14 & 19 & 21 & 22 & 19 & 24 & 17\end{array}$

$\begin{array}{llllllll}22 & 16 & 12 & 23 & 32 & 28 & 16 & 23\end{array}$

$\begin{array}{llllllll}38 & 38 & 14 & 20 & 34 & 25 & 12 & 37\end{array}$

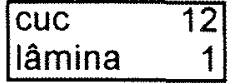

cuc 13

lâmina 1,1

lâmina 1,3

\begin{tabular}{|lr|}
\hline Cuc & 60 \\
lâmina & 2,4 \\
\hline
\end{tabular}

\begin{tabular}{|lr|}
\hline CuC & 63 \\
lâmina & 22 \\
\hline
\end{tabular}

\begin{tabular}{|lr}
\hline Cuc & 65 \\
lâmina & 2,4 \\
\hline
\end{tabular} 
PARCELA II - $12 \times 18$

teste de aspersores no campo

4 aspersores a $12 \times 18 \mathrm{~m}$

24/05/95

cultura:

18-19:00h

aspersores $200 \mathrm{~cm}$

volume em mililitros

teste de aspersores no campo

4 aspersores a $12 \times 18 \mathrm{~m}$

30/05/95

cultura:

18:30--19:10h

aspersores $200 \mathrm{~cm}$

volume em mililitros

teste de aspersores no campo

4 aspersores a $12 \times 18 \mathrm{~m}$

01/06/95

cultura:

$6: 15-6: 45 h$

cultes: $\quad 30 \mathrm{~cm}$

aspersores $200 \mathrm{~cm}$

volume em mililitros

teste de aspersores no campo

4 aspersores a $12 \times 18 \mathrm{~m}$

06/06/95

$18: 10-19: 00 \mathrm{~h}$

cultura:

$82 \mathrm{~cm}$

coletores: $\quad 30 \mathrm{~cm}$

aspersores $200 \mathrm{~cm}$

volume em mililitros

teste de aspersores no campo

4 aspersores a $12 \times 18 \mathrm{~m}$

08/06/95

6:05-7:05

cultura:

$82 \mathrm{~cm}$

coletores: $\quad 30 \mathrm{~cm}$

aspersores $200 \mathrm{~cm}$

volume em mililitros

teste de aspersores no campo

4 aspersores a $12 \times 18 \mathrm{~m}$

21/06/95

cultura:

$136 \mathrm{~cm}$

coletores: $\quad 30 \mathrm{~cm}$

aspersores $200 \mathrm{~cm}$

volume em mililitros

teste de aspersores no campo

4 aspersores a $12 \times 18 \mathrm{~m}$

$22 / 06 / 95$

cultura: $\quad 136 \mathrm{~cm}$

coletores: $\quad 30 \mathrm{~cm}$

aspersores $200 \mathrm{~cm}$

volume em mililitros
63

26

21

26

31

43

37

2

11

11

23

15

17

18
9
9
23
18
12

12
4

4

49
14
45

45
7

13

19

9

23

11

11
58

10

$$
2
$$

14

11

8

1

20

12
15

15
37

37
5

5
1

9
12
5
23
11
31
5
12

$17 \quad 18$

119

$24 \quad 42$

$\begin{array}{ll}37 & 27\end{array}$

860

2630

$16 \quad 14$

$19 \quad 11$

$23 \quad 14$

0

$14 \quad 23$

2218

223

6

$18 \quad 26$

$13 \quad 13$

\begin{tabular}{rr|r|r} 
& \multicolumn{2}{c}{ posição } \\
22 & 83 & 75 \\
6 & 7 & 15 \\
18 & 25 & 45 \\
44 & 32 & 75 \\
49 & 14 & 15 \\
22 & 15 & 45 \\
15 & 22 & 75 \\
5 & 53 & 15 \\
\hline
\end{tabular}

cuc

lâmina

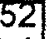

3,1

$$
21 \quad 35
$$

123

$27 \quad 15$

1120

$\begin{array}{ll}5 & 22\end{array}$

183

$19 \quad 32$

$\begin{array}{llll}6 & 5 & 33 & 22\end{array}$

$\begin{array}{llll}0 & 17 & 0 & 5\end{array}$

$\begin{array}{llll}15 & 16 & 4 & 20\end{array}$

$\begin{array}{llll}5 & 18 & 10 & 18\end{array}$

$\begin{array}{llll}1 & 12 & 10 & 3\end{array}$

$\begin{array}{llll}15 & 9 & 14 & 0\end{array}$

$\begin{array}{llll}7 & 15 & 9 & 13\end{array}$

$\begin{array}{llll}11 & 9 & 9 & 0\end{array}$

$\begin{array}{llll}11 & 6 & 8 & 13\end{array}$

$\begin{array}{llll}0 & 15 & 1 & 13\end{array}$

$\begin{array}{llll}25 & 22 & 9 & 17\end{array}$

$\begin{array}{llll}24 & 21 & 15 & 6\end{array}$

$\begin{array}{llll}1 & 32 & 26 & 12\end{array}$

$\begin{array}{llll}22 & 1 & 54 & 1\end{array}$

$\begin{array}{llll}19 & 26 & 16 & 7\end{array}$

$\begin{array}{llll}29 & 12 & 9 & 2\end{array}$

$\begin{array}{llll}20 & 11 & 11 & 28\end{array}$

$\begin{array}{llll}0 & 22 & 4 & 1\end{array}$

$\begin{array}{llll}70 & 28 & 9 & 39\end{array}$

$\begin{array}{llll}73 & 14 & 17 & 10\end{array}$

$\begin{array}{llll}0 & 33 & 11 & 18\end{array}$

$\begin{array}{llll}51 & 11 & 76 & 5\end{array}$

$\begin{array}{llll}24 & 29 & 29 & 7\end{array}$

$\begin{array}{llll}5 & 29 & 16 & 54\end{array}$

$\begin{array}{llll}1 & 17 & 1 & 8\end{array}$

$\begin{array}{llll}75 & 13 & 14 & 17\end{array}$

$\begin{array}{llll}26 & 14 & 11 & 6\end{array}$

$\begin{array}{llll}8 & 27 & 16 & 4\end{array}$

$\begin{array}{llll}55 & 1 & 15 & 1\end{array}$

$\begin{array}{rrrr}23 & 21 & 24 & 1 \\ 4 & 8 & 0 & 3\end{array}$

$\begin{array}{llll}15 & 1 & 8 & 41\end{array}$

$\begin{array}{rrrrr}12 & 0 & 9 & 1 & 29\end{array}$

$\begin{array}{lllll}5 & 6 & 8 & 102 & 16\end{array}$

$\begin{array}{lllll}23 & 8 & 9 & 11 & 5\end{array}$

$\begin{array}{lllll}11 & 5 & 36 & 45 & 3\end{array}$

$\begin{array}{lllll}31 & 64 & 17 & 46 & 18\end{array}$

$\begin{array}{rrrr}20 & 13 & 22 & 6\end{array}$
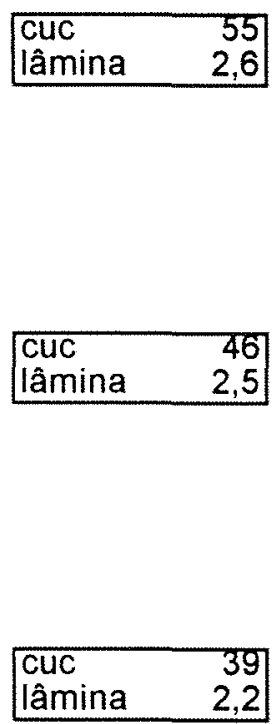
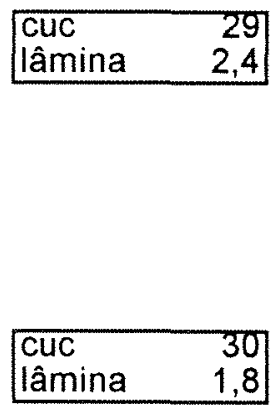

lâmina

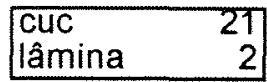


teste de aspersores no campo 4 aspersores a $12 \times 18 \mathrm{~m}$ 28/06/95

$17: 55-18: 55 h$

cultura: $155 \mathrm{~cm}$

coletores: $\quad 30 \mathrm{~cm}$

aspersores $200 \mathrm{~cm}$

volume em mililitros

teste de aspersores no campo

4 aspersores a $12 \times 18 \mathrm{~m}$

17/07/1995 18:50-19:50

cultura: $\quad 175 \mathrm{~cm}$

coletores: $\quad 30 \mathrm{~cm}$

aspersores $200 \mathrm{~cm}$

volume em mililitros

teste de aspersores no campo

4 aspersores a $12 \times 18 \mathrm{~m}$

21/07/95 8:45-9:30

cultura: $\quad 177 \mathrm{~cm}$

coletores: $\quad 30 \mathrm{~cm}$

aspersores $200 \mathrm{~cm}$

volume em mililitros

teste de aspersores no campo

4 aspersores a $12 \times 18 \mathrm{~m}$

26/07/95

$17: 15-18: 15$

cultura:

$180 \mathrm{~cm}$

coletores: $\quad 30 \mathrm{~cm}$

aspersores $200 \mathrm{~cm}$

volume em mililitros

teste de aspersores no campo

4 aspersores a $12 \times 18 \mathrm{~m}$

01/08/95

cultura:

$17: 15-18: 15$

coletores:

aspersores $200 \mathrm{~cm}$

volume em mililitros

teste de aspersores no campo

4 aspersores a $12 \times 18 \mathrm{~m}$

03/08/95

cultura:

$180 \mathrm{~cm}$

coletores: $\quad 30 \mathrm{~cm}$

aspersores $200 \mathrm{~cm}$

volume em mililitros

teste de aspersores no campo

4 aspersores a $12 \times 18 \mathrm{~m}$

07/08/95

cultura:

$180 \mathrm{~cm}$

$17: 40-18: 40$

coletores: $\quad 30 \mathrm{~cm}$

aspersores $200 \mathrm{~cm}$

volume em mililitros

$\begin{array}{rrrrr}10 & 2 & 0 & 8 & 9 \\ 33 & 1 & 19 & 15 & 5 \\ 3 & 1 & 28 & 42 & 6 \\ 10 & 2 & 6 & 4 & 1 \\ 9 & 5 & 16 & 12 & 12 \\ 22 & 98 & 7 & 89 & 37 \\ 1 & 9 & 35 & 19 & 7 \\ 1 & 14 & 30 & 7 & 0 \\ & & & & \\ 0 & 1 & 22 & 0 & 5 \\ 35 & 12 & 54 & 13 & 13 \\ 12 & 22 & 5 & 16 & 10 \\ 1 & 4 & 2 & 1 & 1 \\ 35 & 0 & 12 & 19 & 12 \\ 28 & 48 & 6 & 20 & 23 \\ 0 & 12 & 10 & 33 & 0 \\ 0 & 0 & 13 & 1 & 1\end{array}$

\begin{tabular}{|lr|}
\hline Cuc & 13 \\
lâmina & 1,8 \\
\hline
\end{tabular}

\begin{tabular}{lr}
\hline CuC & 18 \\
lâmina & 1,4 \\
\hline
\end{tabular}
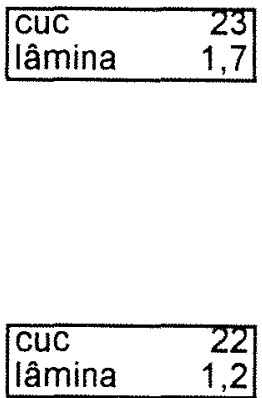

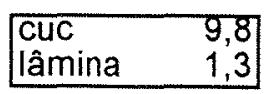

CUC

lâmina

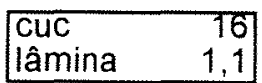

$\begin{array}{rrrrr}0 & 8 & 2 & 0 & 6 \\ 7 & 34 & 24 & 3 & 8 \\ 2 & 7 & 3 & 36 & 21 \\ 10 & 5 & 4 & 22 & 9 \\ 47 & 2 & 55 & 14 & 12 \\ 9 & 34 & 15 & 46 & 26 \\ 1 & 4 & 10 & 10 & 14 \\ 47 & 1 & 12 & 1 & 14\end{array}$


teste de aspersores no campo 4 aspersores a $12 \times 18 \mathrm{~m}$ 09/08/95 cultura: $17: 20-18: 20$ $180 \mathrm{~cm}$ coletores: $\quad 30 \mathrm{~cm}$ aspersores $200 \mathrm{~cm}$

volume em mililitros

teste de aspersores no campo 4 aspersores a $12 \times 18 \mathrm{~m}$ 14/08/95 17:20-18:20 cultura: $\quad 180 \mathrm{~cm}$ coletores: $\quad 30 \mathrm{~cm}$ aspersores $200 \mathrm{~cm}$

volume em mililitros

teste de aspersores no campo 4 aspersores a $12 \times 18 \mathrm{~m}$ 21/08/95 cultura: $180 \mathrm{~cm}$ $17: 30-18: 30$

coletores: $30 \mathrm{~cm}$ aspersores $200 \mathrm{~cm}$

volume em mililitros

teste de aspersores no campo 4 aspersores a $12 \times 18 \mathrm{~m}$ 23/08/95

cultura: $17: 30-18: 30$

coletores: $180 \mathrm{~cm}$ aspersores $200 \mathrm{~cm}$

volume em mililitros

teste de aspersores no campo 4 aspersores a $12 \times 18 \mathrm{~m}$ 29/08/95

cultura: $180 \mathrm{~cm}$

coletores: $\quad 30 \mathrm{~cm}$ aspersores $200 \mathrm{~cm}$

volume em mililitros

teste de aspersores no campo 4 aspersores a $12 \times 18 \mathrm{~m}$ 30/08/95

cultura: $180 \mathrm{~cm}$ 17:15-18:15

coletores: $\quad 30 \mathrm{~cm}$

aspersores $200 \mathrm{~cm}$

volume em mililitros

teste de aspersores no campo 4 aspersores a $12 \times 18 \mathrm{~m}$ 13/09/95

cultura: $17: 20-18: 20$

coletores: $180 \mathrm{~cm}$

aspersores $200 \mathrm{~cm}$

volume em mililitros

\begin{tabular}{|c|c|c|c|c|c|c|}
\hline $\begin{array}{r}0 \\
9 \\
0 \\
8 \\
18 \\
19 \\
0 \\
0\end{array}$ & $\begin{array}{r}0 \\
59 \\
1 \\
6 \\
0 \\
49 \\
13 \\
3\end{array}$ & $\begin{array}{r}0 \\
22 \\
1 \\
3 \\
42 \\
6 \\
28 \\
14\end{array}$ & $\begin{array}{r}0 \\
10 \\
12 \\
21 \\
19 \\
62 \\
14 \\
0\end{array}$ & $\begin{array}{r}4 \\
10 \\
3 \\
3 \\
5 \\
0 \\
0 \\
19\end{array}$ & $\begin{array}{l}\text { Cuc } \\
\text { lâmina }\end{array}$ & $\begin{array}{l}4,8 \\
1,4 \\
\end{array}$ \\
\hline $\begin{array}{r}0 \\
9 \\
0 \\
7 \\
21 \\
3 \\
0 \\
1\end{array}$ & $\begin{array}{r}0 \\
1 \\
1 \\
1 \\
11 \\
39 \\
11 \\
10\end{array}$ & $\begin{array}{r}0 \\
27 \\
0 \\
4 \\
14 \\
10 \\
26 \\
41\end{array}$ & $\begin{array}{r}0 \\
2 \\
9 \\
24 \\
12 \\
88 \\
19 \\
0\end{array}$ & $\begin{array}{r}2 \\
4 \\
2 \\
2 \\
5 \\
9 \\
6 \\
33\end{array}$ & $\begin{array}{l}\text { Cức } \\
\text { lâmina }\end{array}$ & $\begin{array}{l}3,5 \\
1,3\end{array}$ \\
\hline $\begin{array}{r}19 \\
36 \\
10 \\
1\end{array}$ & $\begin{array}{l}2 \\
3 \\
4 \\
3 \\
2\end{array}$ & $\begin{array}{r}47 \\
34 \\
4 \\
12 \\
24\end{array}$ & $\begin{array}{r}1 \\
1 \\
11 \\
10 \\
19\end{array}$ & $\begin{array}{r}28 \\
13 \\
18 \\
3 \\
7\end{array}$ & $\begin{array}{l}\text { Cuc } \\
\text { lâmina } \\
\end{array}$ & $\begin{array}{r}457 \\
25 \\
\end{array}$ \\
\hline
\end{tabular}
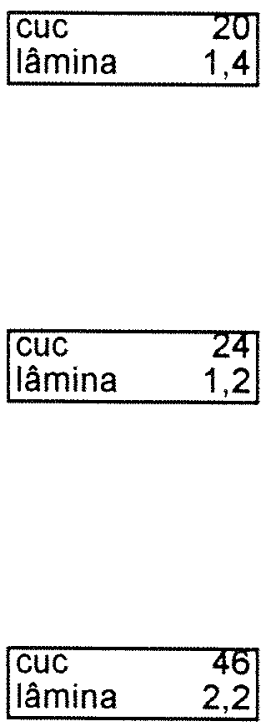
teste de aspersores no campo 4 aspersores a $12 \times 18 \mathrm{~m}$ 06/10/95 $\quad 17-18: 00$ cultura: $\mathrm{cm}$

coletores: $\quad 30 \mathrm{~cm}$ aspersores $200 \mathrm{~cm}$

volume em mililitros

teste de aspersores no campo 4 aspersores a $12 \times 18 \mathrm{~m}$ 09/10/95 $8: 15-9: 15 \mathrm{~h}$

cultura: $\mathrm{cm}$

coletores: $\quad 30 \mathrm{~cm}$

aspersores $200 \mathrm{~cm}$

volume em mililitros

teste de aspersores no campo 4 aspersores a $12 \times 18 \mathrm{~m}$ 10/10/95 $7: 50-8: 50 \mathrm{~h}$

cultura: $\mathrm{cm}$

coletores: $\quad 30 \mathrm{~cm}$ aspersores $200 \mathrm{~cm}$

volume em mililitros

$\begin{array}{lllll}62 & 26 & 21 & 23 & 54 \\ 13 & 24 & 23 & 23 & 23 \\ 10 & 20 & 31 & 32 & 26 \\ 23 & 31 & 47 & 43 & 41 \\ 25 & 32 & 40 & 38 & 30 \\ 18 & 26 & 28 & 22 & 17 \\ 24 & 22 & 20 & 18 & 19 \\ 73 & 28 & 21 & 21 & 63\end{array}$

cuc

lâmina 66 3,4

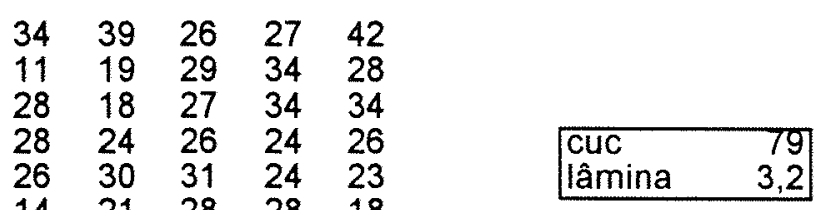


PARCELA III - $6 \times 12$

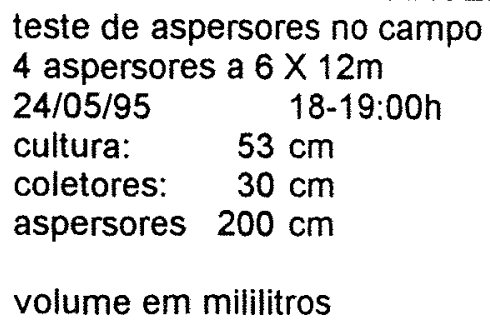

teste de aspersores no campo 4 aspersores a $6 \times 12 \mathrm{~m}$ 30/05/95

cultura: 18:30--19:10h

aspersores $200 \mathrm{~cm}$

volume em mililitros

teste de aspersores no campo

4 aspersores a $6 \times 12 \mathrm{~m}$

01/06/95

cultura:

$6: 15-6: 45 h$

$60 \mathrm{~cm}$

aspersores $200 \mathrm{~cm}$

volume em mililitros

teste de aspersores no campo

4 aspersores a $6 \times 12 \mathrm{~m}$

06/06/95

cultura:

18:10-19:00h

coletores: $\quad 75 \mathrm{~cm}$

aspersores $200 \mathrm{~cm}$

volume em mililitros

teste de aspersores no campo

4 aspersores a $6 \times 12 \mathrm{~m}$

08/06/95

6:05-7:05

cultura:

$75 \mathrm{~cm}$

coletores: $\quad 30 \mathrm{~cm}$

aspersores $200 \mathrm{~cm}$

volume em mililitros

\section{5}

93

75

65

55

62

23

$46 \quad 45$

$80 \quad 183$

52

$\begin{array}{lllll}48 & 51 & 50 & 69 & 59\end{array}$

$\begin{array}{lllll}52 & 62 & 77 & 48 & 37\end{array}$

$\begin{array}{lllll}34 & 14 & 39 & 47 & 13\end{array}$

$\begin{array}{lllll}26 & 48 & 35 & 53 & 52\end{array}$

$\begin{array}{lllll}95 & 37 & 67 & 50 & 58\end{array}$

$\begin{array}{lllll}69 & 26 & 9 & 17 & 78\end{array}$

$\begin{array}{lllll}42 & 30 & 48 & 44 & 45\end{array}$

$\begin{array}{lllll}56 & 37 & 53 & 66 & 98\end{array}$

$\begin{array}{lllll}37 & 26 & 42 & 61 & 65\end{array}$

$\begin{array}{lllll}5 & 31 & 18 & 57 & 9\end{array}$

$\begin{array}{lllll}9 & 22 & 25 & 33 & 38\end{array}$

$\begin{array}{lllll}27 & 46 & 55 & 34 & 27\end{array}$

$\begin{array}{lllll}31 & 23 & 33 & 30 & 3\end{array}$

$\begin{array}{lllll}35 & 60 & 31 & 48 & 40\end{array}$

$\begin{array}{lllll}144 & 25 & 39 & 45 & 26\end{array}$

$\begin{array}{lllll}10 & 35 & 28 & 17 & 18\end{array}$

$\begin{array}{lllll}14 & 13 & 16 & 31 & 12\end{array}$

$\begin{array}{lllll}44 & 32 & 41 & 45 & 41\end{array}$

$\begin{array}{lllll}39 & 39 & 38 & 22 & 37\end{array}$

$\begin{array}{lllll}54 & 11 & 37 & 40 & 78\end{array}$

$\begin{array}{lllll}72 & 22 & 54 & 8 & 51\end{array}$

$\begin{array}{lllll}62 & 124 & 53 & 48 & 49\end{array}$

$\begin{array}{lllll}49 & 27 & 44 & 17 & 6\end{array}$

$\begin{array}{lllll}85 & 49 & 33 & 48 & 56\end{array}$

$\begin{array}{lllll}27 & 128 & 215 & 88 & 43\end{array}$

$\begin{array}{lllll}13 & 10 & 40 & 14 & 26\end{array}$

$\begin{array}{lllll}31 & 23 & 16 & 44 & 48\end{array}$

$\begin{array}{lllll}72 & 91 & 62 & 77 & 78\end{array}$

$\begin{array}{lllll}65 & 58 & 67 & 78 & 60\end{array}$

$\begin{array}{lllll}22 & 19 & 16 & 34 & 77\end{array}$

$\begin{array}{lllll}61 & 22 & 50 & 11 & 73\end{array}$

$\begin{array}{lllll}103 & 50 & 61 & 139 & 39\end{array}$

$\begin{array}{lllll}16 & 46 & 78 & 20 & 9\end{array}$

$\begin{array}{lllll}61 & 39 & 46 & 71 & 55\end{array}$

$\begin{array}{lllll}68 & 57 & 18 & 76 & 101\end{array}$

$\begin{array}{lllll}10 & 14 & 42 & 34 & 29\end{array}$

$\begin{array}{lllll}25 & 37 & 15 & 50 & 4\end{array}$

$\begin{array}{lllll}74 & 45 & 71 & 86 & 68\end{array}$

$\begin{array}{lllll}83 & 70 & 80 & 51 & 69\end{array}$
Cuc $\quad 70$

lâmina $\quad 7,3$

\begin{tabular}{|lr|}
\hline Cuc & 70 \\
lâmina & 8,3 \\
\hline
\end{tabular}

\begin{tabular}{|lr|}
\hline Cuc & 60 \\
lâmina & 7,5 \\
\hline
\end{tabular}

\begin{tabular}{|lr|}
\hline Cự & 54 \\
lâmina & 7,3 \\
\hline
\end{tabular}

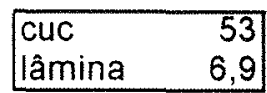


teste de aspersores no campo 4 aspersores a $6 \times 12 \mathrm{~m}$ 21/06/95 16:40-17:40h

cultura: $\quad 136 \mathrm{~cm}$

coletores: $\quad 30 \mathrm{~cm}$

aspersores $200 \mathrm{~cm}$

volume em mililitros

teste de aspersores no campo

4 aspersores a $6 \times 12 \mathrm{~m}$

22/06/95

$18: 45-19: 45 h$

cultura: $\quad 136 \mathrm{~cm}$

coletores: $\quad 30 \mathrm{~cm}$

aspersores $200 \mathrm{~cm}$

volume em mililitros

teste de aspersores no campo

4 aspersores a $6 \times 12 \mathrm{~m}$

28/06/95

$17: 55-18: 55 h$

cultura: $\quad 157 \mathrm{~cm}$

coletores: $\quad 30 \mathrm{~cm}$

aspersores $200 \mathrm{~cm}$

volume em mililitros

teste de aspersores no campo

4 aspersores a $6 \times 12 \mathrm{~m}$

17/07/1995 18:50-19:50

cultura: $\quad 185 \mathrm{~cm}$

coletores: $\quad 30 \mathrm{~cm}$

aspersores $200 \mathrm{~cm}$

volume em mililitros

teste de aspersores no campo

4 aspersores a $6 \times 12 \mathrm{~m}$

21/07/95 8:45-9:30

cultura: $\quad 185 \mathrm{~cm}$

coletores: $\quad 30 \mathrm{~cm}$

aspersores $200 \mathrm{~cm}$

volume em mililitros

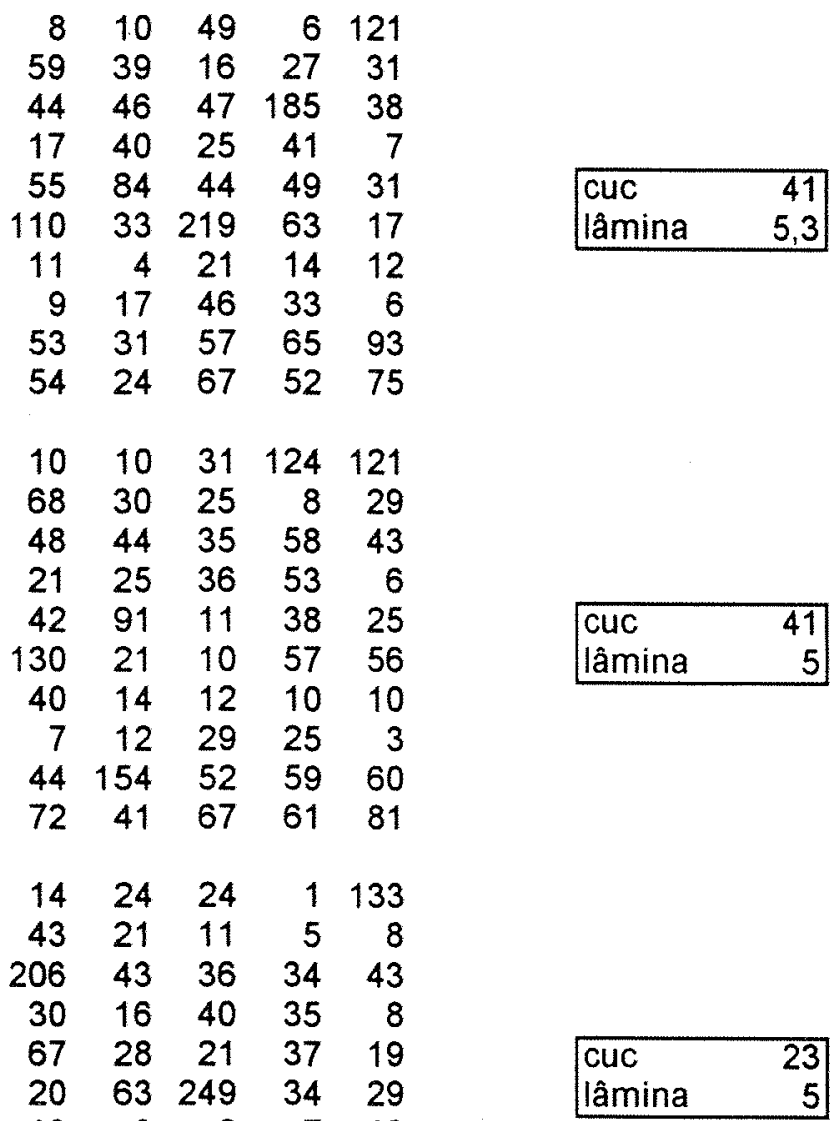

$\begin{array}{lllll}13 & 9 & 2 & 7 & 12\end{array}$

$\begin{array}{lllll}3 & 10 & 15 & 12 & 2\end{array}$

$\begin{array}{lllll}107 & 142 & 45 & 53 & 138\end{array}$

$\begin{array}{lllll}68 & 39 & 61 & 14 & 53\end{array}$

$\begin{array}{lllll}10 & 24 & 4 & 1 & 140\end{array}$

$\begin{array}{lllll}45 & 24 & 1 & 0 & 5\end{array}$

$\begin{array}{lllll}57 & 29 & 67 & 116 & 137\end{array}$

$\begin{array}{lllll}15 & 46 & 58 & 21 & 3\end{array}$

$\begin{array}{lllll}51 & 28 & 38 & 35 & 222\end{array}$

$\begin{array}{rrrrr}135 & 61 & 199 & 140 & 65\end{array}$

$\begin{array}{lllll}50 & 61 & 4 & 22 & 20\end{array}$

$\begin{array}{lllll}20 & 5 & 23 & 42 & 17\end{array}$

$\begin{array}{lllll}42 & 187 & 86 & 55 & 178\end{array}$

$\begin{array}{lllll}40 & 92 & 13 & 18 & 55\end{array}$

$\begin{array}{lllll}20 & 16 & 3 & 0 & 84\end{array}$

$\begin{array}{lllll}28 & 35 & 12 & 2 & 7\end{array}$

$\begin{array}{lllll}18 & 20 & 29 & 83 & 77\end{array}$

$\begin{array}{lllll}7 & 35 & 49 & 27 & 2\end{array}$

$\begin{array}{lllll}33 & 18 & 65 & 30 & 82\end{array}$

$\begin{array}{lllll}36 & 45 & 85 & 82 & 133\end{array}$

$\begin{array}{lllll}30 & 68 & 0 & 13 & 1\end{array}$

$\begin{array}{rrrrr}17 & 6 & 16 & 26 & 16\end{array}$

$\begin{array}{lllll}31 & 84 & 42 & 40 & 55\end{array}$

$\begin{array}{lllll}28 & 44 & 1 & 12 & 19\end{array}$ 
teste de aspersores no campo 4 aspersores a $6 \times 12 \mathrm{~m}$

$\begin{array}{lr}\text { 26/07/95 } & 17: 15-18: 15 \\ \text { cultura: } & 185 \mathrm{~cm} \\ \text { coletores: } & 30 \mathrm{~cm} \\ \text { aspersores } & 200 \mathrm{~cm}\end{array}$

volume em mililitros

teste de aspersores no campo 4 aspersores a $6 \times 12 \mathrm{~m}$ 01/08/95 17:15-18:15 cultura: $\quad 185 \mathrm{~cm}$ coletores: $\quad 30 \mathrm{~cm}$ aspersores $200 \mathrm{~cm}$

volume em mililitros

teste de aspersores no campo 4 aspersores a $6 \times 12 \mathrm{~m}$ 03/08/95 17:20-18:20

cultura: $\quad 185 \mathrm{~cm}$

coletores: $\quad 30 \mathrm{~cm}$

aspersores $200 \mathrm{~cm}$

volume em mililitros

teste de aspersores no campo 4 aspersores a $6 \times 12 \mathrm{~m}$ 07/08/95 17:40-18:40

cultura: $\quad 185 \mathrm{~cm}$

coletores: $\quad 30 \mathrm{~cm}$

aspersores $200 \mathrm{~cm}$

volume em mililitros

teste de aspersores no campo 4 aspersores a $6 \times 12 \mathrm{~m}$ 09/08/95 17:20-18:20

cultura: $\quad 185 \mathrm{~cm}$

coletores: $\quad 30 \mathrm{~cm}$

aspersores $200 \mathrm{~cm}$

volume em mililitros

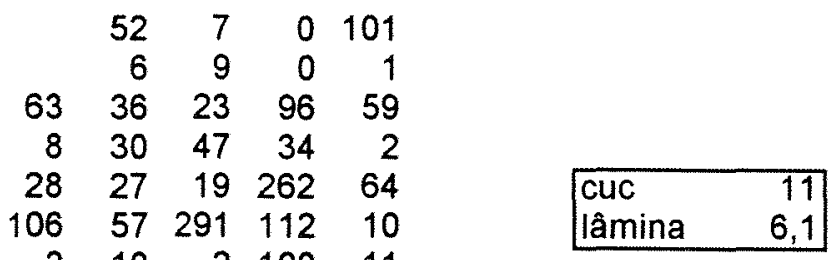

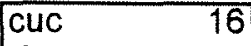

lâmina 4,7
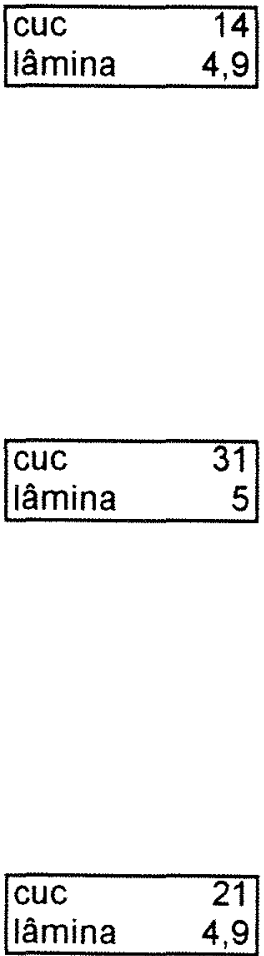
teste de aspersores no campo 4 aspersores a $6 \times 12 \mathrm{~m}$ 14/08/95

cultura: $\quad 185 \mathrm{~cm}$

coletores: $\quad 30 \mathrm{~cm}$

aspersores $200 \mathrm{~cm}$

volume em mililitros

teste de aspersores no campo

4 aspersores a $6 \times 12 \mathrm{~m}$

$21 / 08 / 95$

cultura:

$185 \mathrm{~cm}$

$17: 30-18: 30$

coletores: $\quad 30 \mathrm{~cm}$

aspersores $200 \mathrm{~cm}$

volume em mililitros

teste de aspersores no campo

4 aspersores a $6 \times 12 \mathrm{~m}$

23/08/95 17:30-18:30

cultura: $\quad 185 \mathrm{~cm}$

coletores: $\quad 30 \mathrm{~cm}$

aspersores $200 \mathrm{~cm}$

volume em mililitros

teste de aspersores no campo

4 aspersores a $6 \times 12 \mathrm{~m}$

29/08/95 17:15-18:15

cultura: $\quad 185 \mathrm{~cm}$

coletores: $\quad 30 \mathrm{~cm}$

aspersores $200 \mathrm{~cm}$

volume em mililitros

teste de aspersores no campo

4 aspersores a $6 \times 12 \mathrm{~m}$

30/08/95

$17: 15-18: 15$

cultura: $\quad 185 \mathrm{~cm}$

coletores: $\quad 30 \mathrm{~cm}$

aspersores $200 \mathrm{~cm}$

volume em mililitros

$\begin{array}{rrrrr}2 & 139 & 2 & 0 & 165 \\ 42 & 11 & 2 & 16 & 0 \\ 105 & 27 & 55 & 115 & 43 \\ 1 & 29 & 80 & 35 & 6 \\ 84 & 19 & 80 & 61 & 60 \\ 37 & 23 & 25 & 64 & 78 \\ 24 & 64 & 0 & 7 & 1 \\ 86 & 5 & 37 & 14 & 8 \\ 39 & 299 & 24 & 14 & 49 \\ 44 & 127 & 68 & 23 & 43\end{array}$

\begin{tabular}{|lr|}
\hline Cự & 23 \\
lâmina & 5,6 \\
\hline
\end{tabular}

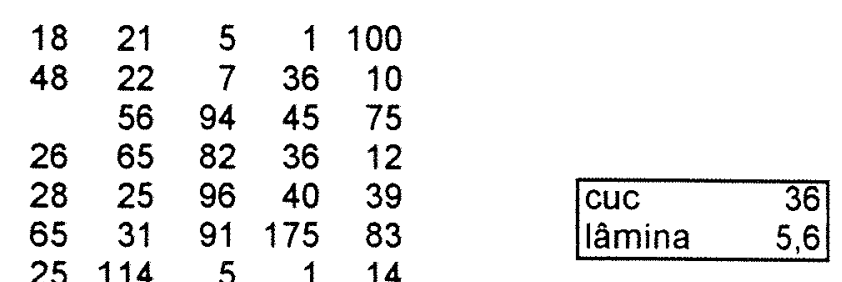

$\begin{array}{rrrrr}25 & 114 & 5 & 1 & 14\end{array}$

$\begin{array}{lllll}22 & 10 & 19 & 45 & 18\end{array}$

$\begin{array}{lllll}81 & 133 & 30 & 46 & 70\end{array}$

$\begin{array}{lllll}34 & 95 & 65 & 31 & 98\end{array}$

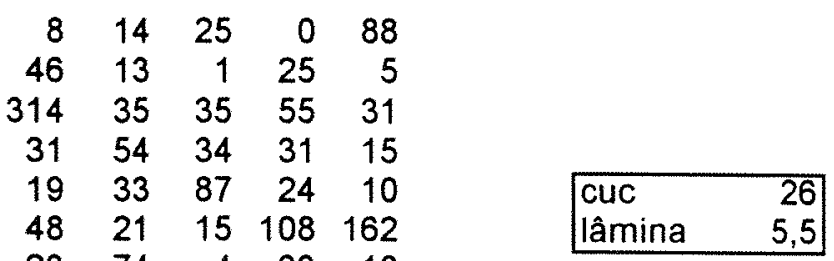

$\begin{array}{lllll}23 & 74 & 4 & 63 & 10\end{array}$

$\begin{array}{lllll}7 & 12 & 33 & 30 & 78\end{array}$

$\begin{array}{lllll}31 & 187 & 24 & 44 & 51\end{array}$

$\begin{array}{lllll}30 & 89 & 54 & 34 & 147\end{array}$

$\begin{array}{lllll}35 & 20 & 19 & 31 & 59\end{array}$

$\begin{array}{lllll}37 & 30 & 10 & 24 & 26\end{array}$

$\begin{array}{lllll}220 & 34 & 35 & 15 & 49\end{array}$

$\begin{array}{lllll}1 & 39 & 36 & 39 & 1\end{array}$

$\begin{array}{lllll}47 & 8 & 20 & 83 & 23\end{array}$

$\begin{array}{lllll}84 & 36 & 93 & 93 & 66\end{array}$

$\begin{array}{lllll}23 & 21 & 8 & 4 & 48\end{array}$

$\begin{array}{lllll}18 & 10 & 22 & 37 & 14\end{array}$

$\begin{array}{lllll}85 & 32 & 28 & 49 & 25\end{array}$

$\begin{array}{lllll}36 & 49 & 48 & 62 & 41\end{array}$

$\begin{array}{lllll}49 & 25 & 14 & 30 & 63\end{array}$

$\begin{array}{lllll}45 & 33 & 8 & 16 & 41\end{array}$

$\begin{array}{lllll}235 & 37 & 55 & 11 & 46\end{array}$

$\begin{array}{lllll}50 & 33 & 26 & 28 & 12\end{array}$

$\begin{array}{lllll}104 & 16 & 21 & 23 & 31\end{array}$

$\begin{array}{lllll}80 & 33 & 99 & 143 & 71\end{array}$

$\begin{array}{lllll}17 & 17 & 6 & 11 & 6\end{array}$

$\begin{array}{lllll}22 & 17 & 22 & 34 & 10\end{array}$

$\begin{array}{lllll}59 & 34 & 25 & 46 & 43\end{array}$

\begin{tabular}{|lr|}
\hline Cuc & 45 \\
lâmina & 4,5 \\
\hline
\end{tabular}

$\begin{array}{lllll}38 & 70 & 4 & 43 & 49\end{array}$ 
teste de aspersores no campo

4 aspersores a $6 \times 12 \mathrm{~m}$

13/09/95 $\quad 17: 20-18: 20$

cultura: $\quad 185 \mathrm{~cm}$

coletores: $\quad 30 \mathrm{~cm}$

aspersores $200 \mathrm{~cm}$

volume em mililitros

teste de aspersores no campo

4 aspersores a $6 \times 12 \mathrm{~m}$

06/10/95

cultura:

17-18:00

coletores: $\quad 30 \mathrm{~cm}$

aspersores $200 \mathrm{~cm}$

volume em mililitros

teste de aspersores no campo

4 aspersores a $6 \times 12 \mathrm{~m}$

09/10/95

cultura:

$8: 15-9: 15 h$

coletores: $\quad 30 \mathrm{~cm}$

aspersores $200 \mathrm{~cm}$

volume em mililitros

teste de aspersores no campo

4 aspersores a $6 \times 12 \mathrm{~m}$

10/10/95

$7: 50-8: 50 \mathrm{~h}$

cultura:

$\mathrm{cm}$

coletores: $\quad 30 \mathrm{~cm}$

aspersores $200 \mathrm{~cm}$

volume em mililitros

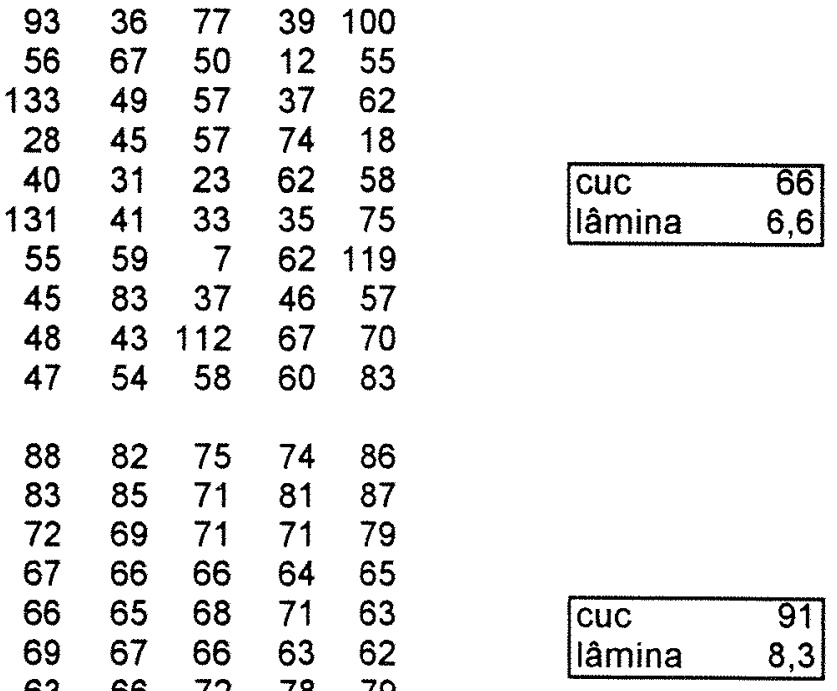

cuc

lâmina $\quad 8,6$

$\begin{array}{lllll}64 & 69 & 77 & 74 & 78\end{array}$

$\begin{array}{lllll}65 & 66 & 69 & 71 & 80\end{array}$

$\begin{array}{lllll}71 & 75 & 64 & 69 & 72\end{array}$

$\begin{array}{lllll}68 & 68 & 66 & 63 & 65\end{array}$

$\begin{array}{lllll}60 & 69 & 78 & 71 & 65\end{array}$

$\begin{array}{lllll}65 & 76 & 74 & 79 & 78\end{array}$

$\begin{array}{lllll}77 & 80 & 85 & 85 & 86\end{array}$

$\begin{array}{lllll}81 & 82 & 83 & 85 & 85\end{array}$

$\begin{array}{lllll}81 & 87 & 96 & 91 & 81\end{array}$

$\begin{array}{lllll}80 & 90 & 88 & 86 & 82\end{array}$

$\begin{array}{lllll}67 & 77 & 85 & 82 & 83\end{array}$

$\begin{array}{lllll}67 & 71 & 73 & 75 & 82\end{array}$

$\begin{array}{lllll}71 & 82 & 73 & 70 & 69\end{array}$

$\begin{array}{lllll}64 & 74 & 77 & 64 & 60\end{array}$

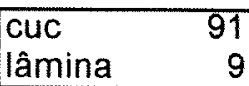


Velocidades mínima e máxima do vento $(\mathrm{m} / \mathrm{s})$ durante os testes

\begin{tabular}{cccc}
\hline Data & Horário & Mínima & Máxima \\
\hline 21/ jul & $8: 45$ a $9: 30 \mathrm{~h}$ & 0,79 & 1,07 \\
26/ jul & $17: 15$ a $18: 15 \mathrm{~h}$ & 1,01 & 1,35 \\
01/ ago & $17: 15$ a $18: 15 \mathrm{~h}$ & 0,65 & 1,24 \\
03/ ago & $17: 20$ a $18: 20 \mathrm{~h}$ & 1,06 & 1,52 \\
07/ ago & $17: 40$ a $18: 40 \mathrm{~h}$ & 0,23 & 1,29 \\
09/ago & $17: 20$ a $18: 20 \mathrm{~h}$ & 1,08 & 1,51 \\
14/ ago & $17: 20$ a $18: 20 \mathrm{~h}$ & $0,93^{*}$ & $1,43^{*}$ \\
21/ago & $17: 30$ a $18: 30 \mathrm{~h}$ & 0,93 & 1,12 \\
23/ ago & $17: 30$ a $18: 30 \mathrm{~h}$ & 0,67 & 1,03 \\
28/ago & $17: 15$ a $18: 15 \mathrm{~h}$ & 0,26 & 1,38 \\
30/ago & $17: 15$ a $18: 15 \mathrm{~h}$ & 0,23 & 1,44 \\
13/ set & $17: 20$ a $18: 20 \mathrm{~h}$ & 0,97 & 1,64 \\
06/ out & $17: 00$ a $18: 00 \mathrm{~h}$ & 0,20 & 1,13 \\
09/out & $8: 15$ a $9: 15 \mathrm{~h}$ & 0,91 & 1,44 \\
10/ out & $7: 50$ a $8: 50 \mathrm{~h}$ & 1,01 & 1,44 \\
\hline
\end{tabular}

*leituras a cada 20 minutos até esta data e a cada 10 minutos a partir dela 
APÊNDICE 6 - Perfil de distribuição de água abaixo da cultura 


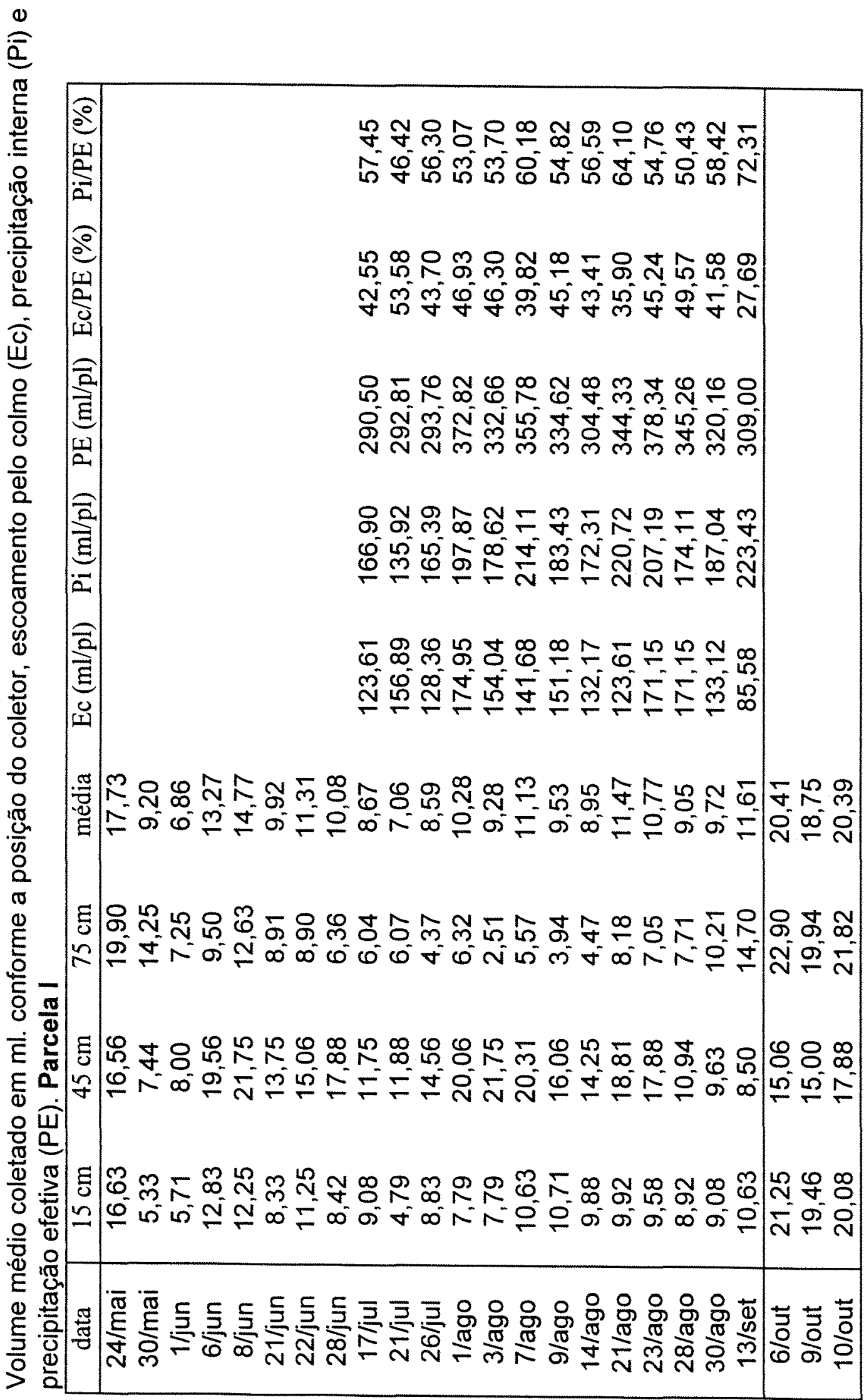




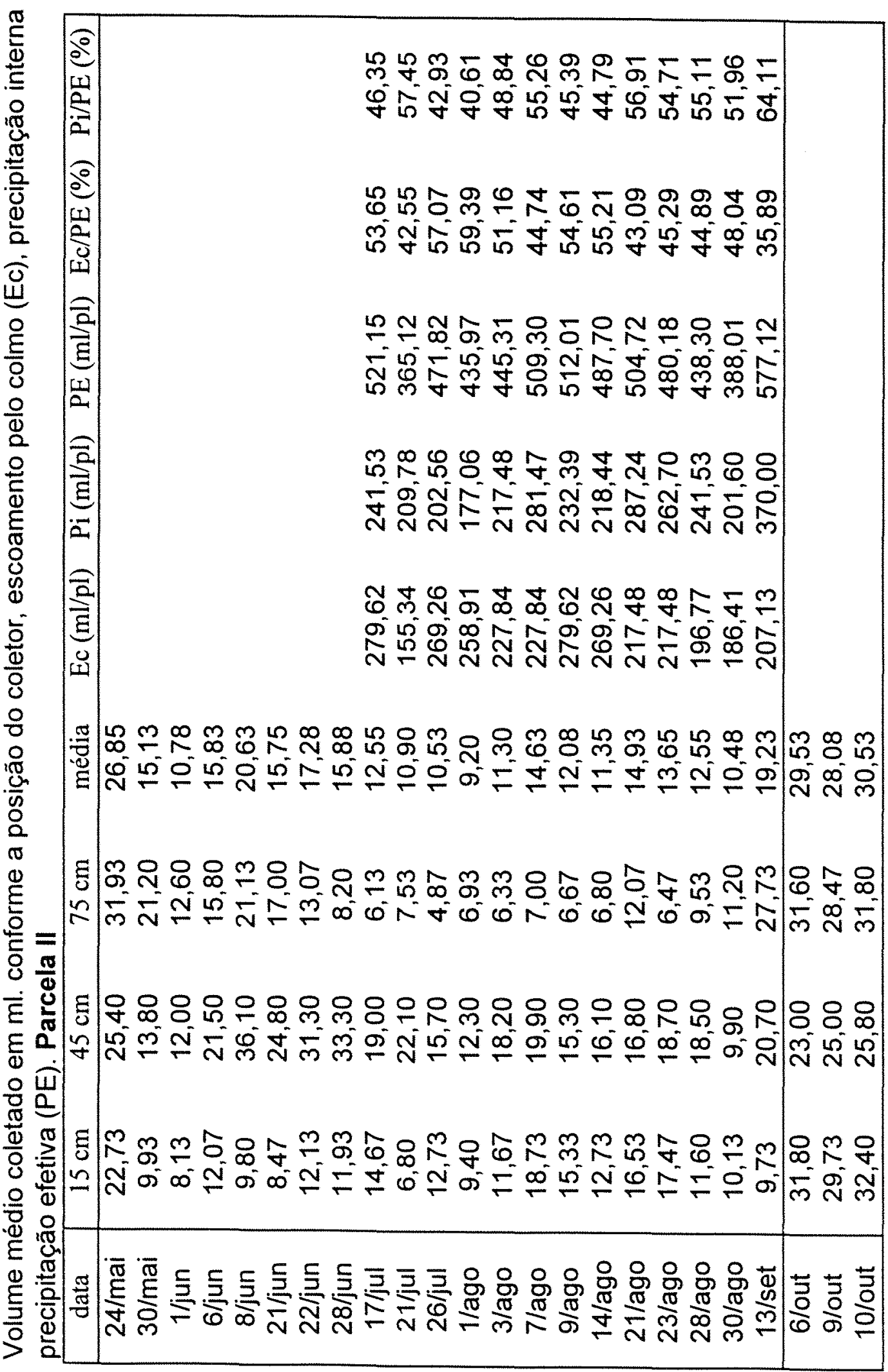




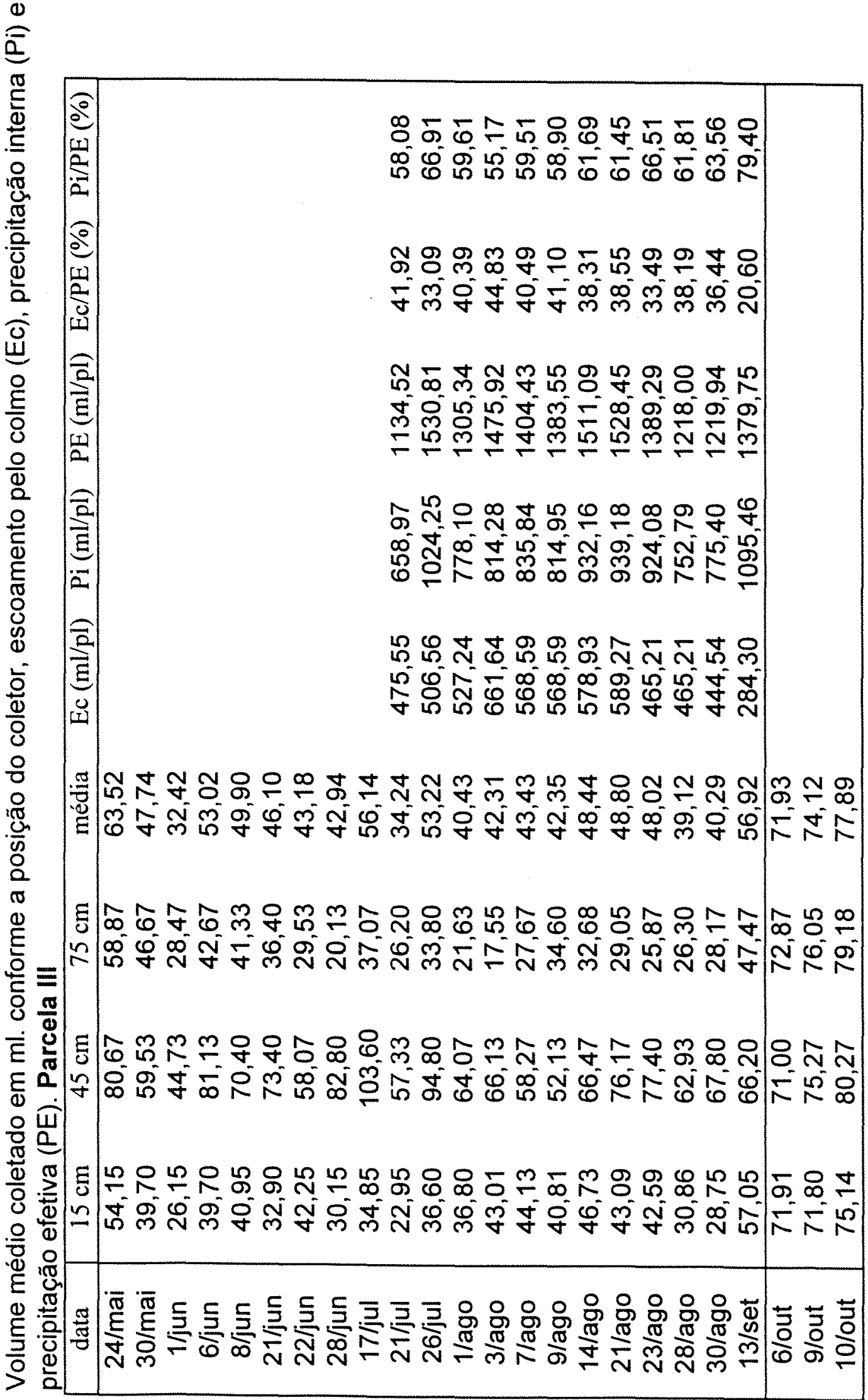

